\title{
CONSUMO HÍDRICO DO TOMATEIRO (Lycopersicon esculentum Mill.) CULTIVADO EM ESTUFA PLÁSTICA E SUA RELAÇÃO COM VARIÁVEIS METEOROLÓGICAS EM SANTA MARIA, RS
}

\section{EVANDRO ZANINI RIGHI}

Engenheiro Agrônomo

Orientador: Prof. Dr. LUIZ ROBERTO ANGELOCCI .

\begin{abstract}
Dissertação apresentada à Escola Superior de Agricultura "Luiz de Queiroz", Universidade de São Paulo, para obtenção de Título de Mestre em Agronomia, Área de Concentração: Agrometeorologia.
\end{abstract}

\author{
PIRACICABA \\ Estado de São Paulo - Brasil \\ Janeiro - 2000
}




\section{ERRATA}

- Na página 8 , no quinto parágrafo, onde se lê “...menor que no exterior, fenômeno denominado "inversão térmica", a qual ocorre em dias..., leia-se ... menor que no exterior, em dias...".

- Na página 9, terceira linha, onde se lê "atenuando", leia-se "amenizando".

- Na página 11, quarto parágrafo, penúltima linha, onde se lê "parâmetro", leia-se "variável".

- Na página 22, no terceiro parágrafo, onde se lê “..., através da equação (Estefanel et al., 1990):", leia-se “..., através da equação de Ângstron \& Prescott apresentada por Estefanel et al. (1990):".

- Na página 27 , primeiro parágrafo, onde se lê “..., para parametrizar com a evapotranspiração de refer6encia, foi obtida multiplicando-se...", leia-se “..., para comparar com a evapotranspiração de referência, multiplicando-se...".

- Na legenda da Figura 3, páginas 31 e 32, onde se lê "PAR", leia-se "DFFA".

- Na página 55 , primeiro parágrafo, linha 6 , onde se lê “..., do que quando esta normalmente estava aberta para ventilar, permitindo que as condiçóes internas fossem fortemente influenciadas pelas externas, obtendo-se coeficientes de determinação mais elevados quando...”, leia-se “..., quando esta normalmente estava aberta para ventilar, permitindo que as condições internas fossem fortemente influenciadas pelas externas, obtendo-se coeficientes de determinação mais elevados do que quando...". 


\section{Dados Internacionais de catalogação na Publicação (CIP) DIVISÃO DE BIBLIOTECA E DOCUMENTAÇÃO - Campus "Luiz de Queiroz"/USP}

\section{Righi, Evandro Zanini}

Consumo hidrico do tomateiro (Lycopersicon esculentum Mill.) cultivado em estufa plástica e sua relaçāo com variảveis meteorológicas em Santa Maria, RS /

Evandro Zanini Righi. - - Piracicaba, 2000.

69 p. : il.

Dissertação (mestrado) - - Escola Superior de Agricultura Luiz de Queiroz, 2000. Bibliografia.

1. Consumo hidrico 2. Crescimentoento vegetal 3. Cultivo em estufa 4. Irrigação 5. Meteorologia agricola 6. Substrato artificial 7. Tomate 8. Transpiraçāo vegetal I. Titulo

CDD 635.642

"Permitida a cópia total ou parcial deste documento, desde que citada a fonte - $\mathrm{O}$ au tor" 
"Somos milhões de transatlânticos falidos em pleno mar da tranqüilidade"

(Zé Ramalho) 


\section{AGRADEC O}

A DEUS, por tudo...

A meus pais, por acreditarem em minha capacidade de enfrentar obstáculos e vencer, pelo apoio e força nos momentos mais difíceis, enfim, a eles também, por tudo.

A todos meus familiares que tiveram uma participação muito importante durante, principalmente, a graduação, e na minha ausência de casa, ao apoio dedicado a meus pais.

A todos amigos, pelas horas mais alegres e que, nas horas mais dificeis, dedicaram seu tempo para me reanimar. A eles em especial: Antonio, Aderbal, Jailson, Robson, Alessandra, a todos os demais moradores da vila da pós-graduação, especialmente aqueles cuja maior convivência foi obtida no ano 1998; aos colegas e grandes amigos Glauco, Karen, Kesia, Marcius, Rafael e Sylvia.

Prof. Dr. Luiz Roberto Angelocci, pela orientação, amizade e por acreditar em minha capacidade.

Por todas as vezes que busquei o afeto familiar na distância de meus pais, agradeço por tudo à tia Maria e ao Jeronimo.

Ao Zeca (o Frei) e sua família que me receberam de braços abertos ao chegar em Piracicaba sem conhecer ninguém.

Aos Professores Galileo Buriol, Arno Heldwein, Valduino Estefanel e Paulo Cesar Sentelhas, pela amizade e tempo dedicado na minha orientação durante a execução do experimento e a elaboração do trabalho.

À ESALQ/USP, em especial aos professores e funcionários, amigos, do Departamento de Ciências Exatas, pelo conhecimento adquirido através de seus ensinamentos.

Um especial agradecimento para a Universidade Federal de Santa Maria, especificamente, ao Departamento de Fitotecnia do Centro de Ciências Rurais, que cedeu sua estrutura e equipamentos para a execução do experimento. 
Aos amigos da UFSM, pela amizade e ajuda na execução do experimento: Josemar, Genei, Astor, Nirlei, Ivonete, Fabio, Luciano (Alemão e o Garfield), Jovani (Luzza), e todos aqueles que trabalharam no Dep. de Fitotecnia da UFSM durante 1999. À CAPES pela concessão da bolsa.

Enfim, a todos aqueles que direta ou indiretamente ajudaram-me e tiveram participação no meu desenvolvimento no decorrer do curso de mestrado.

MUITO OBRIGADO. 


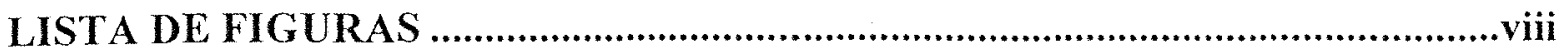

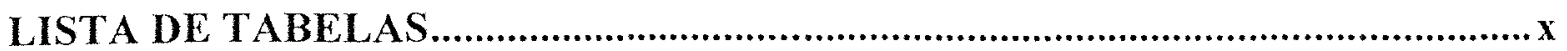

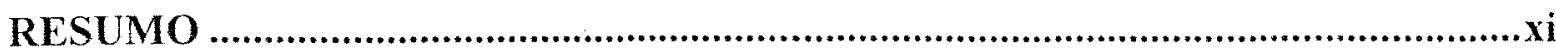

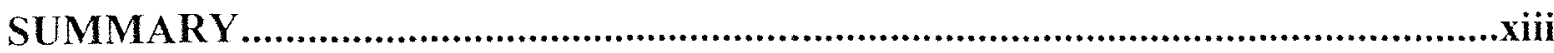

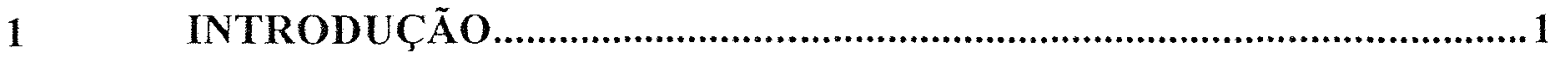

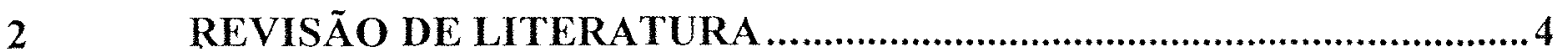

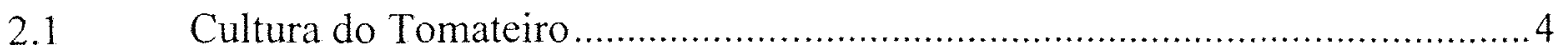

2.2 Efeito da cobertura plástica nas variáveis meteorológicas ……....................... 6

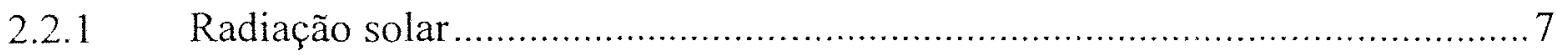

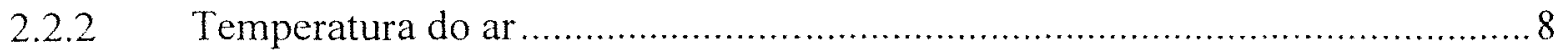

2.2.3 Umidade relativa e pressão de vapor do ar .................................................. 9

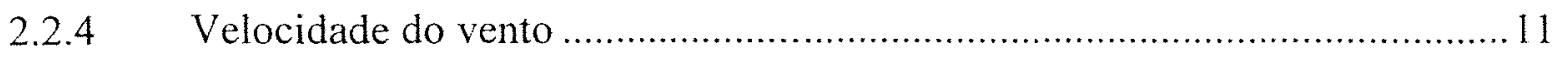

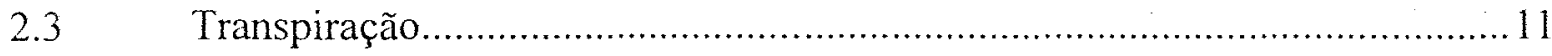

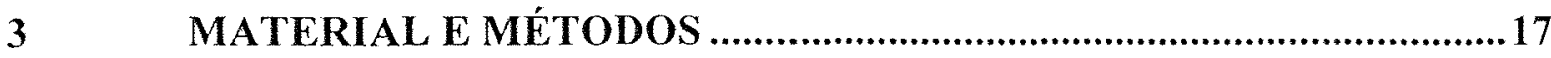

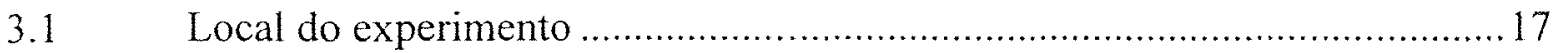

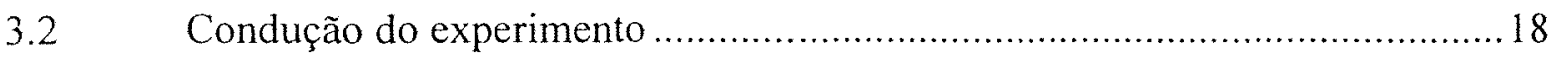

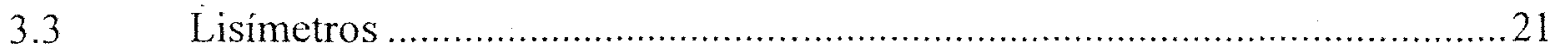

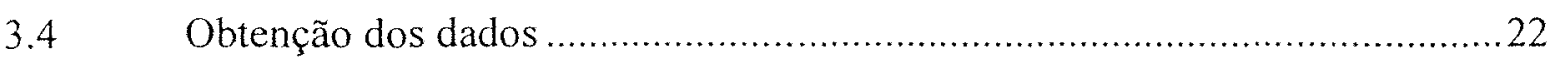

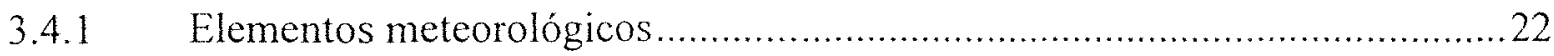

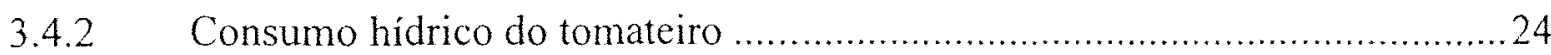

3.4.3 Variáveis de crescimento das plantas .......................................................24

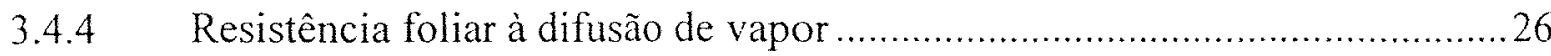

3.5 Razão entre consumo d'água e evapotranspiração de referência (TR/ETo)...27

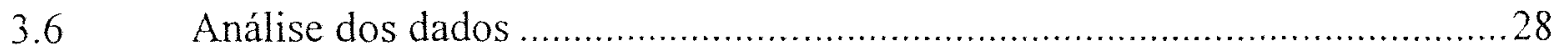

$4 \quad$ RESULTADOS E DISCUSSÃO

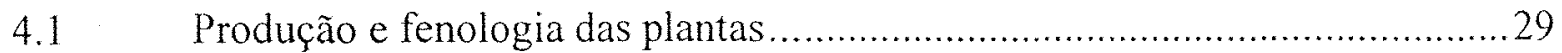

4.2 Monitoramento das condições hídricas nas plantas ......................................22 
4.3 Consumo d'água, parâmetros de crescimento das plantas e variáveis meteorológicas .

4.4 Correlação entre o consumo d'água das plantas $e$ as variáveis meteorológicas

4.5 Correlações múltiplas do consumo d'água diário por unidade de área foliar

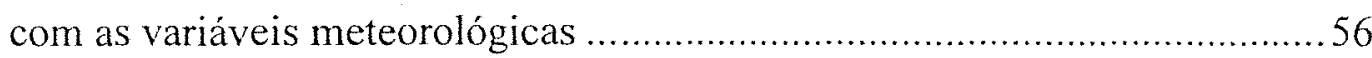

4.6 Razão entre consumo d'água e a evapotranspiração de referência (TR/ETo). 59

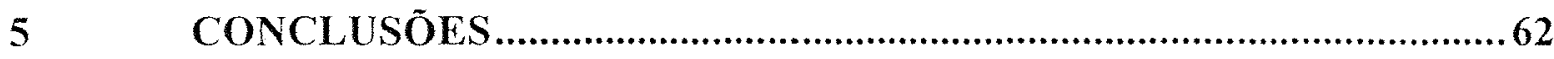

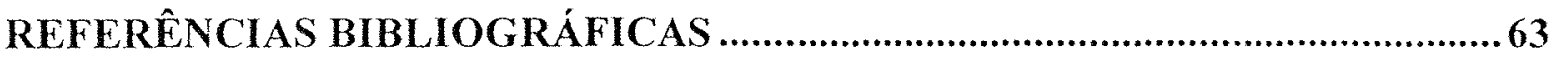




\section{LISTA DE FIGURAS}

1 Esquema da estrutura da estufa utilizada no experimento................................ 18

2 Esquematização do tipo de lisímetro utilizado no experimento..........................21

3 Resistência média das folhas à difusão de vapor $\left(r_{s}\right)$ e da densidade de fluxo fótons fotossinteticamente ativos ( $D F F A$ ) incidente nas folhas para os dias: 19/03/99 (a), 25/03/99 (b), 08/04/99 (c), 14/04/99 (d), 20/04/99 (e), 29/04/99 (f) e $03 / 05 / 99$ (g)

4 Variação diária da diferença entre a temperatura das folhas do tomateiro e a temperatura do ar $\left(t_{f} T\right)$, médias de 24 medidas, nos dias 19 e 25 de março, 8 , 14,20 e 29 de abril e 3 de maio

5 Correlação entre a resistência média das folhas à difusão de vapor $\left(r_{s}\right)$ e a densidade de fluxo de fótons fotossinteticamente ativos (DFFA).

6 a) Densidade de fluxo de radiação solar global incidente $\left(R g_{e}\right)$ e a radiação líquida, no exterior da estufa $\left.\left(R n_{e}\right) ; b\right)$ temperatura média diária do ar no interior $\left(t_{m i}\right)$ e exterior $\left(t_{m e}\right)$ da estufa.

7 Umidade relativa média diária do ar no interior $\left(U R_{m i}\right)$ e exterior $\left(U R_{m e}\right)$ da estufa e déficit de saturação do ar no interior $\left(D_{i}\right)$ e exterior $\left(D_{e}\right)$ da mesma.......37

8 a) Consumo d'água diário por planta $(C O N S)$ e área foliar média das plantas $(A F)$; b) altura $(A L T)$ e número de folhas $(N F)$ médios por planta de tomateiro.

9 Consumo d'água diário por planta de tomateiro (CONS) e a densidade de fluxo de radiação solar global incidente no exterior da estufa $\left(R g_{e}\right)$

10 Consumo d'água diário por unidade de área foliar (CONSf) e déficit de saturação do ar diário no interior da estufa $\left(D_{i}\right)$

11 Correlação entre o consumo d'água diário por unidade de área foliar do tomateiro (CONSf) e a densidade de fluxo de radiação solar global no exterior da estufa $\left(R g_{e}\right)$ para as diferentes faixas de valores da temperatura média do ar no exterior da estufa $\left(t_{m e}\right)$ 
12 Correlação entre o consumo d'água diário por unidade de área foliar (CONSf)

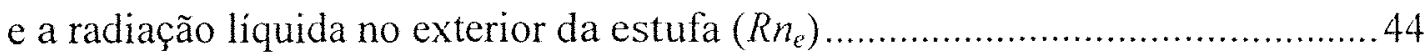

13 Correlação entre o consumo d'água diário por unidade de área foliar (CONSf) e a temperatura do ar no interior da estufa: a) média diária $\left(t_{m i}\right)$; b) máxima

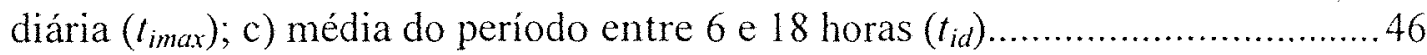

14 Correlação entre o consumo d'água diário por unidade de área foliar (CONSf) e a umidade relativa do ar diária no interior da estufa: a) média $\left(U R_{m i}\right)$; b) mínima $\left(U R_{\text {imin }}\right)$; $\left.\mathrm{c}\right)$ média no período entre 6 e 18 horas $\left(U R_{i d}\right)$

15 Correlação entre o consumo d'água diário por unidade de área foliar (CONSf) e o déficit de saturação do ar diário no interior da estufa $\left(D_{i}\right)$ 48

16 Correlação do consumo d'água diário por unidade área foliar (CONSf) com a temperatura diária do ar no exterior da estufa: a) média $\left(t_{m e}\right)$; b) máxima $\left(t_{\text {emax }}\right)$

17 Correlação do consumo d'água diário por unidade área foliar (CONSf) com a umidade relativa média diária do ar no exterior da estufa $\left(U R_{m e}\right)$ conforme faixas dos valores da temperatura média diária do ar no exterior da mesma $\left(t_{m e}\right)$ : a) $15^{\circ} \mathrm{C} \leq t_{m e}<20^{\circ} \mathrm{C}$; b) $t_{m e}<15^{\circ} \mathrm{C}$

18 Correlação do consumo d'água diário por unidade área foliar (CONSf) com a umidade relativa do ar no exterior da estufa medida às 15 horas $\left(U R_{/ 5}\right)$ conforme faixas da temperatura média diária do ar no exterior da mesma $\left(t_{m e}\right)$ : a) $15^{\circ} \mathrm{C} \leq t_{m e}<20^{\circ} \mathrm{C} ;$ b) $t_{m e}<15^{\circ} \mathrm{C}$

19 Correlação do consumo d'água diário por unidade de área foliar (CONSf) com: a) o déficit de saturação do ar diário no exterior da estufa $\left(D_{e}\right)$; b) com o déficit de saturação do ar calculado para as 15 horas $\left(D_{e} l 5\right)$

20 Flutuação diária e das médias semanais da razão entre a transpiração do tomateiro e a evapotranspiração de referência (TR/ETo) e sua linha de ajuste. 


\section{LISTA DE TABELAS}

1 Quantidade de fertilizante aplicado semanalmente por planta e para as 15 plantas dos lisímetros.

2 Modelos obtidos por regressão múltipla, do consumo d'água diário por unidade de área foliar do tomateiro (CONSf) cultivado no interior de uma estufa plástica com as variáveis meteorológicas do exterior da estufa e seus respectivos coeficientes de determinação $\left(R^{2}\right)$, considerando-se 105 observações...

3 Modelos obtidos por regressão múltipla, do consumo d'água diário por unidade de área foliar do tomateiro (CONSf) cultivado no interior de uma estufa plástica com as variáveis meteorológicas do interior da estufa e seus respectivos coeficientes de determinação $\left(R^{2}\right)$, considerando-se 105

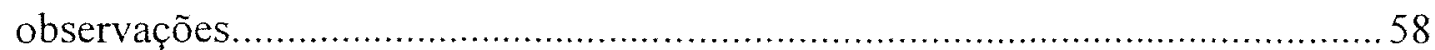

4 Intervalo de valores utilizados de cada variável meteorológica dos modelos.....59 


\title{
CONSUMO HÍDRICO DO TOMATEIRO (Lycopersicon esculentum Mill.) CULTIVADO EM ESTUFA PLÁSTICA E SUA RELAÇÃO COM VARIÁVEIS METEOROLÓGICAS EM SANTA MARIA, RS
}

\author{
Autor: EVANDRO ZANINI RIGHI \\ Orientador: Prof. Dr. LUIZ ROBERTO ANGELOCCI
}

\section{RESUMO}

Normalmente, o cultivo do tomateiro no interior de estufas plásticas é realizado diretamente no solo, mas devido aos problemas de salinização e doenças, os produtores tem optado por sistemas de cultivo em substratos. Devido ao volume do ambiente radicular reduzido, uma eficiente irrigação torna-se necessária, carecendo de maior precisão das estimativas de consumo d'água pelas plantas. Para isto, é interessante o estudo das relações entre o consumo hídrico e as variáveis meteorológicas e crescimento das plantas. Desta forma, determinou-se o consumo d'água do tomateiro de hábito de crescimento determinado, estudou-se o efeito das variáveis meteorológicas isolado do efeito das variáveis de crescimento das plantas, utilizando-se o consumo d'água por unidade de área foliar, e identificou-se quais são as variáveis meteorológicas mais importantes a afetá-lo, em cultivo de outono-inverno, em estufa localizada no Campo Experimental do Departamento de Fitotecnia do Centro de Ciências Rurais da Universidade Federal de Santa Maria. A estufa com dimensões $10 \mathrm{~m} \times 24 \mathrm{~m}$, foi manejada manualmente, com ventilação natural através de janelas laterais e portas frontais. Cada planta de tomateiro de hábito de crescimento determinado. cultivar Imperror, foi conduzido em 8 litros de substrato comercial Plantmax, em três lisimetros coletores de drenagem, com cinco plantas cada, sendo cada lisímetro irrigado no início da manhã de todos os dias do período experimental (27/02/99 - 04/07/99). A densidade de fluxo de radiação solar global e a radiação líquida foram estimadas para o exterior da 
estufa a partir de dados da estação meteorológica próxima à estufa. A temperatura. a umidade relativa e o déficit de saturação do ar foram determinados no interior da estufa, a partir dos dados de um termohigrógrafo, e no seu exterior, a partir de dados da estação meteorológica. A evolução das variáveis meteorológicas durante o período experimental foi característica para o local e época do ano, com uma redução gradativa da densidade de fluxo de radiação solar, da temperatura e do déficit de saturação do ar e aumento da umidade relativa do ar. Foram encontradas boas correlações entre o consumo hídrico por unidade de área foliar com a irradiância solar global, e melhor ainda com a radiação líquida, no exterior da estufa, mas o melhor ajuste do consumo hídrico foi obtido com a variável déficit de saturação do ar no interior da estufa. Os valores médios diários e diurnos das variáveis meteorológicas no interior da estufa explicaram melhor a variação da transpiração das plantas do que os valores extremos ou de determinados horários do dia. Na comparação entre o efeito das variáveis meteorológicas do interior e exterior da estufa, as primeiras correlacionaram-se melhor com os dados de consumo d'água por unidade de área foliar. A razão consumo d'água/evapotranspiração de referência no exterior da estufa, no cultivo de outono-inverno, aumentou inicialmente em função, principalmente, da área foliar, para depois decrescer, como resposta da redução da demanda hídrica do ar atmosférico. 


\title{
WATER CONSUMPTION OF TOMATO PLANTS (Lycopersicon esculentum Mill.) CULTIVATED IN A PLASTIC GREENHOUSE AND ITS RELATIONSHIP WITH METEOROLOGICAL VARIABLES IN SANTA
}

MARIA, RS, BRAZIL

\author{
Author: EVANDRO ZANINI RIGHI \\ Adviser: Prof. Dr. LUIZ ROBERTO ANGELOCCI
}

\section{SUMMARY}

Usually, tomato cultivation inside plastic greenhouses is done directly in the soil, but due to salinity and diseases problems, the producers have chosen for cultivation systems in substratum. Due to the reduced root volume, an efficient irrigation becomes necessary, requiring more precise estimates of plant water consumption. Therefore, the study of relationships between the water consumption and the meteorological and growth of plants variables that allow precise and accurate estimates of plant transpiration are needed. A study was set up in a $10 \mathrm{~m} \times 24 \mathrm{~m}$ greenhouse located in the Experimental Field of the Department of Plant Production, Federal University of Santa Maria, RS, Brazil. Natural ventilation in the greenhouse was provided by manually operating the opening/shooting of the lateral windows and frontal doors. The plants were cultivated using 8 liters of a comercial substratum, in three drainage lysimeters, with five plants each, being each lysimeter irrigated every day in the early morning during the experimental period (end February-begin July). The plant water consuption per leaf area unit was correlated with meteorological variables inside and outside the greenhouse. The flow density of global solar radiation and net radiation were estimated for the outside of the greenhouse starting from meteorological data observed near the greenhouse. Temperature, relative humidity and vapor deficit were determined inside the greenhouse from thermohygrograph records and on the outside from weather station data. The 
evolution of the meteorological variables during the experimental period was a local characteristic during the year, with a gradual reduction of global solar radiation, temperature, and vapor deficit, and a increase of relative humidity. The water consumption per leaf area unit of the plants correlated well with the solar radiation and better with the net radiation outside the greenhouse, but in the autumn-winter period, the best was obtained with the vapour deficit inside the greenhouse. The mean values in the 24-h and in daytime scales of the meteorological variables inside the greenhouse explained better the variation plants transpiration than the extreme values or those from specific times. In the comparison between the effect of the meteorological variables measured inside and outside the greenhouse, the first ones were better correlated with the data of water consumption by unit of leaf area. The ratio between water consumption of plants and reference evapotranspiration in the outside of greenhouse initially increased and obtained a maximum value of 1,95 about 87 days after transplanting, then decreasing, even without reduction of the leaf area, as a consequence of the reduction of the atmospherical demand. 


\section{INTRODUÇÃO}

No Rio Grande do Sul, ocorreu um aumento significativo da área cultivada em ambiente protegido nos últimos anos, pelo ingresso de novos plasticultores e expansão por parte dos já existentes. Da área total cultivada em ambientes protegidos, $80 \%$ tem sido utilizada com tomateiro por ser a cultura mais rentável e de maior mercado consumidor.

Normalmente, o cultivo em ambiente protegido, comumente chamado de "estufa plástica", realiza-se diretamente no solo, onde tem ocorrido problemas de salinização e tem se tornado fonte de inóculo de doenças. Estes problemas tem levado os produtores a utilizarem sistemas de cultivo fora do solo, como fertirrigação e hidroponia. No Rio Grande do Sul os produtores tem optado em utilizar o cultivo em substratos, os quais já podem ser confeccionados na própria propriedade com baixo custo, além de, dependendo dos cuidados do produtor, ser possivel seu uso em vários ciclos. O cultivo em hidroponia não tem ganhado muito espaço no Estado pelo relativamente alto custo de implantação da estrutura, por ser um sistema de cultivo novo e pouco conhecido na região, e por existirem riscos como alta dependência da energia elétrica e contaminação da solução por patógenos, que por ser reciclada pode contaminar todas as plantas.

A grande expansão da área cultivada sob estufas plásticas e, consequentemente, o crescimento da sua importância econômica, tem direcionado pesquisadores e extensionistas a dar uma atenção especial para os cultivos protegidos, a fim de subsidiar técnicos e produtores na otimização de sua utilização, no aperfeiçoamento das técnicas utilizadas, na redução dos custos de produção e no aumento da produtividade das culturas. 
Os programas de pesquisa na área, até o momento foram dirigidos principalmente ao estudo da quantificação dos elementos físicos relacionados com o manejo destes ambientes; do manejo e produtividade das culturas; do manejo da irrigação; da adaptação de cultivares; da fertilidade do solo e nutrição da planta; e do controle fitossanitário.

Entretanto, existe carência de estudos em relação à fisiologia da cultura cultivada no interior de estufas plásticas, especialmente quanto à relação do consumo d'água pelas plantas com as variáveis meteorológicas. É necessário estudar o efeito destas variáveis sobre as plantas para o desenvolvimento de modelos matemáticos para estimar o consumo d'água com precisão, visto ser a irrigação onerosa e atualmente os recursos hídricos estarem escasseando, tornando-se a cada dia mais difícil obter água abundante e de qualidade adequada para a irrigação.

Este quesito torna-se ainda mais importante ao cultivar-se em substrato, onde o volume do ambiente radicular limitado torna necessário irrigações freqüentes, que, se mal dosadas, podem lixiviar os nutrientes ou causar o acúmulo de sais, prejudicando o desenvolvimento da cultura.

As estufas plásticas permitem que, nas condições climáticas da região de Santa Maria, RS, sejam realizados dois cultivos anuais do tomateiro, de outono-inverno e de primavera-verão. Entretanto, nestes dois períodos de cultivo o consumo d'água pelas plantas é afetado de forma diferenciada pelas variáveis meteorológicas (Dalssaso, 1997; Caron, 1999; Valandro, 1999). No período de outono-inverno, a redução da radiação solar incidente, em função do encurtamento dos dias e da maior inclinação dos raios solares em relação a superfície, com a conseqüente redução da temperatura do ar e maior freqüência de ocorrência de nevoeiros (Estefanel et al., 1998), resulta numa gradual e contínua diminuição da demanda atmosférica, ao mesmo tempo em que a planta está em crescimento. Na primavera, todas estas grandezas aumentam concomitantemente, resultando em uma elevação constante do consumo d'água com o crescimento das plantas. Por isto, no cultivo de outono-inverno existe grande dificuldade em identificar o efeito das variáveis meteorológicas no consumo hídrico, visto apresentarem efeito contrário ao do crescimento das plantas. 
Nos trabalhos realizados até o momento com tomateiro cultivado em estufa em Santa Maria, utilizaram-se somente cultivares de hábito de crescimento indeterminado, que normalmente são plantas mais altas e menos ramificadas, se comparadas às de hábito de crescimento determinado, principalmente em função de sua condução (Chamarro Lapuerta, 1995). Da mesma forma que existem respostas diferenciadas entre as espécies no consumo d’água em relação às variáveis meteorológicas, de crescimento e morfológicas da planta (Baille et al., 1994), é de se esperar que possa ocorrer o mesmo entre plantas de tomateiro com hábito de crescimento diferenciado, mesmo que algumas variáveis da planta como área foliar, massa da matéria fresca e/ou seca sejam semelhantes, porém, a arquitetura é diferente.

Os trabalhos de Dalsasso (1997) e Valandro (1999) evidenciaram a necessidade de mais estudos buscando identificar quais e como as variáveis meteorológicas afetam a transpiração, principalmente no período de outono-inverno. Por isso, é importante a obtenção de mais dados, especialmente para cultivos em substrato, cujos estudos estão em fase inicial, para a elaboração de modelos para a estimativa do consumo d'água das plantas possibilitando a automatização da irrigação em culturas protegidas sem o uso de solo.

O presente trabalho tem como objetivo determinar o consumo d'água do tomateiro de hábito de crescimento determinado cultivado em substrato no interior de uma estufa plástica em Santa Maria, RS, e relacioná-lo com as variáveis meteorológicas do interior e exterior da mesma. 


\section{REVISÃO DE LITERATURA}

\subsection{Cultura do Tomateiro}

O cultivo do tomateiro (Lycopersicon esculentum Mill.) adquiriu importância em todo mundo e seu consumo tem aumentado constantemente (EsquinasAlcazar \& Nuez, 1995). Conforme Casseres (1984), é a hortaliça mais importante por sua popularidade, sua ampla adaptação às diferentes condições climáticas e pela grande quantidade de ingressos no comércio de produtos comestíveis, frescos e industrializados.

No Brasil, Tavares de Melo (1991) considerou o tomateiro a hortaliça mais importante do ponto de vista econômico e social, pelo volume e valor da produção, gerando um grande número de serviços de forma direta ou indireta. Segundo Makishima (1989), é uma das espécies mais consumidas por todas as classes sociais da população, cultivado em todos os Estados da Federação e nas mais diferentes condições agroclimáticas.

O tomateiro é uma planta herbácea dicotiledônea pertencente a família das Solanáceas. Originária da região andina, desenvolve-se bem em climas tropicais, sendo uma cultura perene, comumente cultivada como anual (Esquinas-Alcazar \& Nuez, 1995).

De acordo com a cultivar, seu desenvolvimento pode ser rasteiro, semiereta ou ereta, com crescimento limitado ou ilimitado, nas variedades de hábito de crescimento determinado e indeterminado, respectivamente (Rick, 1978), sendo que primeira inflorescência surge após a emissão de 6 a 12 folhas. Os sucessivos segmentos do caule se desenvolvem de forma similar, produzindo uma inflorescência a cada 3 folhas nas cultivares de hábito de crescimento indeterminado. Nas cultivares de hábito 
de crescimento determinado, o ramo que emite a inflorescência cessa seu crescimento, surgindo novas inflorescências nos ramos laterais, resultando em plantas mais prostradas daquelas de hábito de crescimento indeterminado (Chamarro Lapuerta, 1995).

Em condições de produção sem limitação nutricional e hídrica, as variáveis meteorológicas assumem grande importância no desenvolvimento do tomateiro. Em intervalos de 2 a 3 dias ocorre a formação de folhas novas. A produção de folhas e primórdios foliares, em geral, se intensifica com o aumento da intensidade de radiação solar diária e com o aumento da temperatura (Kinet, 1977). O tempo que decorre entre a fecundação da flor até o amadurecimento do fruto depende principalmente da variedade, da intensidade da radiação solar e da temperatura do ar, oscilando geralmente entre 30 e 40 dias (Cermeño, 1979).

O tomateiro se desenvolve bem em ampla gama de valores de temperatura, preferindo ambientes quentes e com boa iluminação (Rick, 1978). Para um bom desenvolvimento das plantas e para assegurar a completa maturação dos frutos, as temperaturas devem ser relativamente elevadas. Um rápido desenvolvimento ocorre com valores diurnos compreendidos entre 20 e $25^{\circ} \mathrm{C}$ e noturno entre 13 e $18^{\circ} \mathrm{C}$ (Robledo de . Pedro \& Martin, 1981). Porém, deve-se ter cuidado com as temperaturas extremas ao seu desenvolvimento. O crescimento do tomateiro é inibido a partir da temperatura de $33^{\circ} \mathrm{C}$ e paralisa seu crescimento acima de $35^{\circ} \mathrm{C}$. Em contra partida, temperaturas abaixo de 10 a $12{ }^{\circ} \mathrm{C}$ também paralisam seu crescimento, entrando em senescência ao ser exposto a temperaturas de 0 a $2^{\circ} \mathrm{C}$. Ventos quentes ou frios podem provocar aborto das flores (Anderlini, 1982).

Uma polinização sem problemas é fundamental para a produção, sendo ideal a umidade relativa do ar não inferior a $70 \%$ e a temperatura do ar entre 17 e $24^{\circ} \mathrm{C}$ para facilitar a aderência do pólen ao estigma e. consequentemente, ocorrer uma boa germinação do tubo polínico (Ravestjin, 1970).

A temperatura ótima para o desenvolvimento da cultura do tomateiro depende da densidade de fluxo de radiação solar (Picken et al., 1986). Trabalhos recentes, realizados em ambientes protegidos no período invernal mostraram que a produtividade é determinada não só pelas temperaturas mas também pela 
disponibilidade de energia solar (Cockshull et al., 1992; Gary et al., 1996). O limite trófico para o tomateiro situa-se em tomo de $8,4 \mathrm{MJ} \mathrm{m}^{-2} \mathrm{dia}^{-1}(\mathrm{FAO}, 1990)$.

Para as condições de Santa Maria, RS, Estefanel et al. (1998) constataram que entre o $3^{\circ}$ decêndio de maio e o $2^{\circ}$ decêndio de julho a probabilidade de ocorrerem valores médios diários de radiação solar limitantes para o desenvolvimento do tomateiro (valores $<8,4 \mathrm{MJ} \mathrm{m}^{-2} \mathrm{dia}^{-1}$ ) é superior a $50 \%$, passando de $70 \%$ no $3^{\circ}$ decêndio de julho. Portanto, em Santa Maria deve ser evitado o cultivo da hortaliça entre junho e julho, período mais problemático, mesmo com a utilização de ambientes protegidos. Porém, neste período, normalmente a cultura encontra-se no final do seu ciclo, sendo mantida até que as condições ambientais permitam sua produção, principalmente no que refere à maturação dos frutos, como é o caso do tomateiro.

Em relação às temperaturas no exterior da estufa, entre 3 de junho e 22 de agosto, na região de Santa Maria, existe probabilidade superior a $20 \%$ de ocorrência de temperaturas inferiores a $2^{\circ} \mathrm{C}$, temperaturas letais para a cultura do tomateiro, mais de $50 \%$ de chance de ocorrência de temperaturas inferiores a $9^{\circ} \mathrm{C}$ do dia 14 de abril ao dia 14 de novembro, o que permite seu cultivo a campo somente na primavera-verão (Estefanel et al., 1988). Porém, no verão podem ocorrer temperaturas altas prejudiciais à cultura. Entre o terceiro decêndio de dezembro e o primeiro de fevereiro existe a probabilidade superior a $30 \%$ de ocorrência de temperaturas maiores de $32^{\circ} \mathrm{C}$ à campo (Estefanel et al., 1994), podendo, facilmente alcançar $35^{\circ} \mathrm{C}$ no interior da estufa, principalmente se não houver ventilação.

\subsection{Efeito da cobertura plástica nas variáveis meteorológicas}

No Rio Grande do Sul, a utilização de ambientes protegidos, ou estufas plásticas, objetiva a produção de culturas tipicamente tropicais nos meses mais frios do ano, permitindo colheitas mais tardias no período de outono-inverno, ou mais precoces no início da primavera, ou mesmo durante o inverno, porém, neste com risco de perda elevado. 
A utilização de coberturas plásticas nas estufas acarreta modificações na variaçâo das diferentes variáveis meteorológicas, principalmente, na densidade de fluxo de radiação solar, temperatura, umidade relativa e déficit de saturação do ar e velocidade do vento, formando um microambiente limitado pelo filme plástico. A variação deste microambiente depende do manejo da estufa, do material de cobertura da mesma e das condições meteorológicas externas.

\subsubsection{Radiação solar}

A densidade de fluxo de radiação solar global incidente no interior da estufa é menor que aquele encontrado no exterior (Martin et al., 1982). Segundo Robledo de Pedro \& Martin (1981), o polietileno de baixa densidade (PEBD), material plástico mais utilizado na "plasticultura" mundial, deixa passar em média 70 a $80 \%$ da densidade de fluxo de radiação solar global incidente no exterior da estufa, chegando a um máximo de $95 \%$.

Normalmente, durante a noite ocorre formação de uma película d'água na superfície interior do filme plástico, pela condensação da umidade do ar, a qual diminui a densidade de fluxo de radiação solar transmitida para o interior da estufa no início da manhã enquanto a água condensada não evapora. Entretanto, deve-se ressaltar que esta película d'água apresenta o efeito positivo de interceptar mais radiação de onda longa, mantendo o ambiente mais aquecido durante a noite (Robledo de Pedro \& Martin, 1981; Farias, 1991; Buriol et al., 1995).

A redução da quantidade de energia radiante incidente no interior da estufa, especialmente a radiação fotossinteticamente ativa, pode comprometer parcialmente a fotossíntese. Porém, este problema é amenizado pelo aumento da relação radiação difusa/radiação direta causada pela ação do plástico/condensação, sendo aquela melhor aproveitada pelas plantas por ser multidirecional (Robledo de Pedro, 1987; Farias et al., 1993a; Buriol et al., 1995), principalmente quando as mesmas apresentam valores de área foliar relativamente elevados, o que causa sombreamento das folhas inferiores (Martinez Garcia, 1978). 


\subsubsection{Temperatura do ar}

O efeito da cobertura da estufa sobre a temperatura do ar está intimamente relacionado com o balanço de energia. Este efeito depende principalmente da transmissividade do plástico e o ângulo de incidência da radiação solar sobre a cobertura (Martinez Garcia, 1978; Prados, 1986; Buriol et al., 1995). Além destes fatores, segundo Seeman (1979), o tipo de solo e principalmente a relação volume/área da estufa podem alterar o efeito da cobertura sobre a temperatura do ar.

Resultados experimentais têm mostrado que a temperatura média do ar no interior da estufa é mais elevada do que no exterior (Montero et al., 1985; Robledo de Pedro \& Martin, 1988; Millis et al., 1990). Porém, às vezes estas diferenças não chegam a ser significativas (Farias et al., 1993b).

O maior efeito da cobertura plástica ocorre nas temperaturas máximas do ar, devido, o ar aquecido ficar retido pela mesma no período diurno, não sendo perdido por convecção como ocorre no exterior da estufa, principalmente se ela não dispõe de dispositivos de ventilação (Farias et al., 1993b).

A temperatura mínima do ar no interior das estufas cobertas com polietileno de baixa densidade (PEBD) tende a ser igual ou ligeiramente superior à observada externamente (Montero et al., 1985; Millis et al., 1990; Buriol et al., 1993).

Heldwein et al. (1995) obtiveram temperaturas mínimas médias a 1,5m do solo $2^{\circ} \mathrm{C}$ superior à do exterior e em dias de geada forte, $3^{\circ} \mathrm{C}$. Entretanto, Buriol et al., (1993) relataram que podem ocorrer dias em que a temperatura do ar no interior da estufa é menor que no exterior, fenômeno denominado "inversão térmica", a qual ocorre em dias de ventos fortes que renovam constantemente a camada de ar junto a superfície do ambiente externo. Porém, nos dias de vento, no Sul do Brasil as temperaturas não são baixas de forma a prejudicar as culturas. Outro aspecto levantado pelos autores é a ocorrência das maiores diferenças entre as temperaturas minimas no interior e exterior da estufa nos dias mais frios.

Nos dias límpidos e sem vento, com grande perda radiativa, que condiciona a ocorrência de geadas, a temperatura do ar no interior das estufas é sempre 
mais elevada daquela do exterior. Isto ocorre em função da formação da camada de condensação na superfície interna da cobertura plástica, a qual reduz a transmissividade à radiação de onda longa, atenuando as temperaturas mínimas. Esta condição pode ser melhorada pelo tipo de material de cobertura da estufa, o qual, quanto mais impermeável for à radiação de onda longa, maior será o chamado efeito "estufa" (Alpi \& Tognoni, 1987).

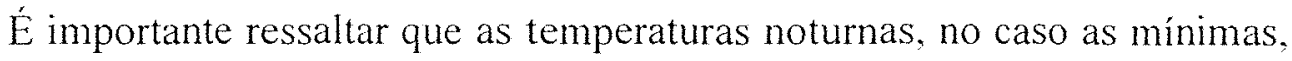
são muito influenciadas pela hora de fechamento da estufa e pela vedação da mesma. Em dias frios, fechando-se a estufa mais cedo para aquecer o ambiente interno, pode-se obter um ganho extra de energia para a noite, principalmente se a estrutura da estufa for bem vedada, diminuindo assim as perdas advectivas (Buriol et al., 1993).

\subsubsection{Umidade relativa e pressão de vapor do ar}

A umidade relativa do ar é uma importante variável meteorológica na produção agricola. Em plantas de tomateiro conduzidas sob condições de umidade do ar elevada, ocorreu redução da área foliar e deficiência mineral, principalmente de cálcio (Bakker, 1990 e Adams, 1991 citados por Jolliet et al., 1993). Rosemberg (1974) encontrou problemas de desenvolvimento em plantas expostas a umidade relativa do ar em torno de $100 \%$, em função da redução da translocação de solutos com a redução da transpiração. Além destes problemas, o molhamento das folhas favorece a instalação de doenças nas plantas.

A umidade relativa do ar é a razão entre a pressão atual de vapor e a pressão de saturação. A pressão de saturação do ar varia positivamente de forma exponencial com a temperatura do ar, enquanto que a pressão atual depende da evaporação no ambiente. Assim, para uma mesma pressão atual de vapor, a umidade relativa do ar é inversamente proporcional à temperatura (Rosemberg. 1974; Seeman, 1979, Tubelis \& Nascimento, 1985; Prados, 1986).

Como a evaporação depende das condições hídricas do solo e sua condutividade hidráulica, e da cobertura vegetal, não havendo grandes diferenças de 
evaporação interna e externa à estufa, durante o período diurno, o aumento mais intenso da temperatura do ar no interior da estufa leva à ocorrência de valores de umidade relativa do ar inferiores aos externos até aproximadamente as 14 horas. Posteriormente, com a redução da quantidade de radiação solar incidente e a conseqüente queda da temperatura do ar, associada ao fechamento da estufa, a umidade relativa do ar aumenta mais rapidamente do que no exterior, atingindo já no final da tarde valores mais elevados. Porém, as médias diárias da umidade relativa do ar no interior da estufa são maiores daquelas observadas no exterior, visto que durante a noite e em dias em que as aberturas para ventilação da estufa são mantidas fechadas, os valores internos são superiores aos externos em função da cobertura plástica impedir dissipação do ar úmido. Embora a umidade relativa do ar no interior da estufa atinja valores menores daqueles observados no exterior para determinados horários diurnos sob determinadas condições meteorológicas, a pressão atual de vapor do ar será sempre mais elevada no interior da estufa (Buriol et al., no prelo).

A pequena permeabilidade do filme plástico ao vapor d'água somada à baixa renovação do ar interno da estufa, leva a valores elevados da umidade relativa do ar (Robledo de Pedro \& Martin, 1981; Bailey, 1985), tornando necessário a utilização de sistemas de ventilação eficientes (Seeman, 1979), os quais normalmente aumentam os custos de produção. Desta forma, uma boa alternativa para renovação do ar da estufa é o manejo correto das aberturas para ventilação. Entretanto, este tipo de manejo, nos períodos de baixa temperatura, pode provocar o abaixamento da mesma no interior da estufa e/ou reduzir o armazenamento de energia para a noite (Tanaka \& Genta, 1983).

Os valores médios de umidade relativa do ar no interior da estufa são mais elevados em relação aos observados a céu aberto. Porém, a sua variação ao longo do dia é maior do que no exterior, com valores elevados à noite, próximo à 100\%, e muito baixos durante o período diurno, próximo a $20 \%$ em condições de climas áridos como na Espanha (Prados, 1986). Resultados similares foram obtidos em Pelotas, RS, por Farias et al. (1993b), onde verificou-se um aumento na amplitude diária da umidade relativa do ar. 


\subsubsection{Velocidade do vento}

O vento aumenta a renovação do ar em torno da folha, aumentando a condutância aerodinâmica, resultando $\mathrm{em}$ valores da transpiração das plantas mais elevados. No interior da estufa, quando ventilada, ocorre a varredura do ar úmido, entrando ar mais seco, que também contribui para o aumento da transpiração, e menos quente do exterior.

A cobertura plástica é um empecilho para a circulação do ar no interior da estufa, principalmente do ar exterior para o interior. Buriol et al. (1997) verificaram maiores valores de temperatura e umidade relativa do ar em túneis baixos mantidos mais tempo fechados, impedindo a ventilação natural.

Jolliet \& Bailey (1992) trabalharam em um túnel de vento com tomateiro,

encontrando um aumento da transpiração em mais de $50 \%$ com o aumento de $1 \mathrm{~m} \mathrm{~s}^{-1}$ na. velocidade do vento em plantas em fase inicial do desenvolvimento.

\subsection{Transpiração}

A transpiração é afetada por fatores da própria planta e ambientais, entre eles, as condições atmosféricas (Kramer \& Boyer, 1995). O aquecimento das folhas pela absorção de radiação solar aumenta o déficit de pressão de vapor entre o dossel das plantas e o ambiente, enquanto que a abertura estomática reduz a resistência ao fluxo de vapor. Estes dois fatores podem combinar com a forte correlação da radiação solar com a temperatura e umidade do ar interno à estufa, resultando em uma relação linear entre a transpiração e a radiação solar (Stanghellini, 1994), a qual tem sido o parâmetro tomado como referência na automatização da irrigação em cultivos em estufas plásticas.

A relação de causa e efeito existente entre a radiação solar e a evapotranspiração máxima $(E T m)$ permite a correlação elevada que ocorre entre os valores de ambas. Esta correlação, segundo De Villele (1972) é do tipo: 


$$
E T m=a \frac{R g_{i}}{\lambda}+b
$$

sendo $R g_{i}$ a radiação solar global incidente sobre o dossel da cultura no interior da estufa $\left(\mathrm{cal} \mathrm{cm} \mathrm{cm}^{-2}\right), \lambda$ o calor latente de vaporização $\left(60 \mathrm{cal} \mathrm{cm}^{-2} \mathrm{~mm}^{-1}\right)$ e $a$ e $b$ coeficientes experimentais da equação de regressão. Para a ETm diária $\left(\mathrm{mm} \mathrm{dia}^{-1}\right)$, os valores de $a$ e $b$ encontrados foram:

$$
E T m=0,67 \frac{R g_{i}}{\lambda}+0,2
$$

A concordância da variação do consumo d'água com a radiação solar incidente sobre a cultura tem sido mostrada principalmente por pesquisadores como De Villele, (1972), Stanhill (1974) e De Graaf \& Van Den Ende (1981).

Atualmente, com a utilização de sistemas de cultivo em substrato, onde existe a necessidade de irrigações mais freqüentes em função do volume do ambiente radicular limitado, tornou-se necessário estimar a transpiração em espaços de tempo menores, por exemplo, em escala horária, que se baseada somente na radiação solar podem ião ser suficientemente precisas. A utilização de modelos baseados na equação de Penman-Monteith, o qual leva em consideração uma componente radiativa que pode ser considerada proporcional à radiação solar incidente sobre a cultura, e uma componente advectiva que depende principalmente do déficit de saturação do ar, geralmente tem resultado em estimativas mais precisas (Baille, 1994). Autores como Stanghellini (1987), Yang et al. (1990) e Boulard et al. (1991) propuseram modelos analíticos, considerando como variáveis meteorológicas somente a radiação solar e o déficit de saturação do ar e como variáveis da planta a resistência estomática e o índice de área foliar $(I A F)$.

Baille et al. (1991) mediram a transpiração de roseiras em estufa equipada com sistema de nebulização. Quando o sistema não foi acionado, para valores de densidade de fluxo de radiação solar superiores a $400 \mathrm{~W} \mathrm{~m}^{-2}$ o aumento da transpiração tendeu a estabilizar. Este efeito foi amenizado com a nebulização, quando a transpiração aumentou até valores de densidade de fluxo de radiação solar superiores a $600 \mathrm{~W} \mathrm{~m}^{-2}$. Os autores atribuíram este fato a um mecanismo de regulação da planta em função da baixa 
umidade relativa do ar, quando o sistema de nebulização não foi acionado, confirmando a necessidade de mais informações na estimativa da transpiração das plantas além da radiação solar.

Boulard et al. (1991) desenvolveram um modelo para a cultura do tomateiro considerando como força motriz da transpiração o déficit de saturação folha-ar $\left(D_{f}\right)$ e como parâmetro de desenvolvimento da planta o índice de área foliar $(I A F)$ :

$$
\begin{aligned}
& \lambda E=\frac{\rho \cdot C p}{\gamma} I A F \frac{D_{f}}{r_{r}} \\
& D_{f}=e_{s}\left(t_{f}\right)-e_{d}
\end{aligned}
$$

sendo $\lambda \mathrm{E}$ a densidade de fluxo de calor latente usado na transpiração ( $\mathrm{W} \mathrm{m}^{-2}$ ), $\rho$ a densidade do ar $\left(\mathrm{kg} \mathrm{m}^{-3}\right), C p$ a capacidade calorifica $\left(\mathrm{J} \mathrm{kg}^{-1} \mathrm{~K}^{-1}\right), \gamma$ a constante psicrométrica $\left(\mathrm{mb} \mathrm{K}^{-1}\right), r_{t}$ a resistência média da cobertura à transferência de vapor d'água $\left(\mathrm{s} \mathrm{m}^{-1}\right), D_{f}$ o déficit de saturação de vapor folha-ar $(\mathrm{mb}), e_{s}\left(t_{f}\right)$ a pressão de saturação $(\mathrm{mb})$ calculado em função da temperatura da folha $\left(t_{f}, \mathrm{em}{ }^{\circ} \mathrm{C}\right)$ e $e_{a}$ a pressão atual de vapor do ar (mb). Este modelo exige a determinação da $t_{f}$ para o cálculo do $D_{f}$, incorrendo em muitos erros devido à falta de precisão na sua determinação, em função da grande heterogeneidade do perfil da temperatura das folhas no dossel das plantas.

Os autores testaram, então, uma simplificação do modelo de PenmanMonteith, no qual os elementos meteorológicos necessários para o cálculo da $\lambda E$ são obtidos com maior facilidade com os dispositivos de aquisição de dados disponíveis:

$$
\lambda E=\frac{\Delta \cdot r_{t \prime \prime}}{\Delta \cdot r_{t c}+\gamma \cdot r_{i}} R g_{u b s}+\frac{\rho \cdot C p . I A F}{\Delta \cdot r_{c t}+\gamma \cdot r_{i}} D_{i}
$$

em que $R g_{a b s}$ é a radiação solar absorvida pela cobertura vegetal $\left(\mathrm{W} \mathrm{m}^{-2}\right), D_{i}$ é o déficit de saturação do ar no interior da estufa $(\mathrm{mb}), \Delta$ é a tangente da curva de pressão de saturação $\left(\mathrm{mb} \mathrm{kg}^{-1}\right)$ e $r_{a e}$ a resistência aerodinâmica da folha $\left(\mathrm{s} \mathrm{m}^{-1}\right)\left(r_{a t}=r_{d} / 2\right.$, sendo $r_{a l}$ a resistência aerodinâmica total). Os valores estimados, quando comparados com aqueles obtidos com um lisímetro de pesagem em uma estufa climatizada e cultivada com tomateiro, foram bastante satisfatórios. Neste trabalho ficou evidente a importância da componente advectiva da equação a qual foi responsável por $40 \%$ da $\lambda E$ total. 
A partir dos resultados obtidos por Boulard et al. (1991), Boulard \& Jemaa (1993) separaram as duas componentes, definindo a primeira parte do modelo multiplicando a $R g_{a b s}$ como um coeficiente $A$ (coeficiente radiativo) e a segunda parte multiplicando $D_{i}$, como um coeficiente $B$ (coeficiente advectivo):

$$
\lambda E=A \cdot G_{a b s}+B \cdot D_{i}
$$

em que:

$$
\begin{aligned}
& A=\frac{\Delta \cdot r_{a w^{\prime}}}{\Delta \cdot r_{t t^{\prime}}+\gamma \cdot r_{r}} \\
& B=\frac{\rho \cdot C p \cdot L A F}{\Delta \cdot r_{c t}+\gamma \cdot r_{r}}
\end{aligned}
$$

A partir das medidas com lisímetro, os autores determinaram os coeficientes $A$ e $B$ por regressão múltipla, considerando as variáveis independentes, $R g_{a b s}$ e $D_{i}$ medidas, os quais foram comparados aos calculados com as equações (7) e (8). Os valores obtidos por regressão múltipla, considerando o período diurno, superestimaram $A$ e sub-estimaram $B$, sendo iguais aos calculados para o período noturno. Conforme os autores, o erro de estimativa pela regressão durante o dia se deve à dependência do $D_{i}$ em função da radiação solar $\left(\mathrm{R}^{2}=0,60\right)$. O coeficiente $B$ correlacionou-se positivamente com o $I A F$ tanto para os valores diurnos como noturnos, evidenciando a importância de se considerar o crescimento da planta na transpiração, no entanto, o coeficiente $A$ não foi influenciado.

Baille et al. (1992) testaram o modelo de Penman-Monteith estimando a resistência do dossel em função de $R g_{i}$ e de $D_{i}$ em culturas ornamentais obtendo boa precisão dos valores estimados comparados aos medidos. Jolliet \& Bailey (1992) não encontraram influência significativa da temperatura da folha e da concentração de $\mathrm{CO}_{2}$ na resistência estomática do tomateiro.

Trabalhando com 9 espécies de plantas ornamentais, Baille et al. (1994) calcularam os coeficientes da equação simplificada de Penman-Monteith, os quais foram específicos para cada espécie, existindo uma resposta diferenciada quanto a importância do termo radiativo e advectivo. 
O estádio de desenvolvimento da cultura também influencia na importância da $R g_{i}$ e do $D_{i}$ na transpiração. Resultados obtidos por Jolliet \& Bailey (1992) mostraram um aumento da importância de $D_{i}$ e uma diminuição de $R g_{i}$ na transpiração com o desenvolvimento da planta em função do aumento da $A F$. Um aumento do $D_{i}$ de $0,1 \mathrm{kPa}$ resultou em um aumento da transpiração de $0,013 \mathrm{~mm} \mathrm{dia}^{-1}$ quando as plantas eram jovens. contra $0.24 \mathrm{~mm} \mathrm{dia}^{-1}$ quando no final do ciclo, enquanto que um aumento de $1 \mathrm{MJ} \mathrm{m}^{-2}$ na $R g_{i}$ proporcionou um aumento da transpiração de $0,089 \mathrm{~mm} \mathrm{dia}^{-1}$ em plantas jovens contra $0,14 \mathrm{~mm} \mathrm{dia}^{-1}$ em plantas no final do ciclo. No . mesmo trabalho, a transpiração estimada com coeficientes obtidos por regressão múltipla com $R g_{i}$ e $D_{i}$ para um determinado $I A F$ foi bastante precisa, demonstrando que modelos simplificados podem ser utilizados para estimar a transpiração das culturas. Os coeficientes da regressão com médias horárias não diferiram significativamente daqueles obtidos com médias diárias para o mesmo $\operatorname{IAF}\left(\lambda E=0,141 . R g_{i}+28,1 . D_{i}\right.$, média horária; $\lambda E=0,137 . R g_{i}+29,9 . D_{i}$, média diária).

Scatolini (1996) obteve como principais fatores determinantes da transpiração da cultura do crisântemo em estufa plástica, a radiação solar e o índice de área foliar. As demais variáveis meteorológicas não representaram variações superiores a $1 \%$ do total estimado, porém, com modelos mais completos, a dispersão dos dados foi reduzida.

Okuya \& Okuya (1988) encontraram uma alta correlação da transpiração do tomateiro em ambientes protegidos com a densidade de fluxo de radiação solar medida no exterior da estufa $\left(R g_{e}\right)$ e $D_{i}$ no interior, tanto em correlações simples $\left(\mathrm{R}^{2}=0,96\right.$ e $\mathrm{R}^{2}=0,86$, respectivamente) como em uma correlação múltipla $\left(\mathrm{R}^{2}=0,98\right)$.

Em cultivos em solo, nas condições climáticas de Santa Maria, RS, Dalsasso (1997) obteve uma boa relação entre o consumo d'água e $R g_{e}$ para o cultivo do tomateiro na safra de primavera-verão, o mesmo não ocorrendo na de outono-inverno. Porém, coeficientes de determinação mais elevados foram obtidos quando correlacionado o consumo d'água com a evaporação do tanque Classe A, mais número de folhas por planta no cultivo de primavera-verão e temperatura média do ar, mais . insolação e mais número de folhas por planta no outono-inverno. O consumo d'água 
médio diário por planta variou de $0,387 \mathrm{~kg}$ planta $^{-1} \mathrm{dia}^{-1}$ no cultivo de outono-inverno para $0,540 \mathrm{~kg}$ planta $^{-1}$ dia $^{-1}$ no cultivo de primavera-verão.

Valandro (1999) mediu o consumo d’água do tomateiro de hábito de crescimento indeterminado, cultivar Monte Carlo, cultivado em substrato no interior de uma estufa plástica, encontrando uma boa relação com $R g_{e}\left(R^{2}=0,65\right)$ no cultivo de primavera-verão, não tendo a mesma relação no cultivo de outono-inverno $\left(R^{2}=0,46\right)$, como já verificado por Dalsasso (1997). Porém, o mesmo autor verificou a existência de correlação do consumo d'água com outras variáveis meteorológicas além da $R g_{e}$, como umidade relativa $\left(U R_{m i}\right)$ e temperatura $\left(t_{m i}\right)$ médias do ar no interior da estufa, e variáveis de crescimento da planta como a área foliar $(A F)$ e o número de folhas $(N F)$. A $U R_{m i}$ foi a variável que resultou no melhor ajuste de dados no cultivo de outono-inverno.

Durante o cultivo de outono-inverno, há redução da energia solar disponível, o que na região de Santa Maria é agravado neste período pela freqüente presença de nevoeiros (Estefanel et al., 1998). Desta forma, a diminuição da densidade do fluxo de radiação solar e da demanda atmosférica coincide com o crescimento das plantas, quando as mesmas necessitam de maior quantidade de energia. Isto faz com que exista no início do desenvolvimento da cultura um aumento do consumo d'água com o crescimento da planta, estabilizando mais adiante e finalmente decrescendo, mesmo com valores máximos de área foliar.

No cultivo de primavera-verão os elementos meteorológicos assumem maior importância pelo aumento da intensidade do fluxo de radiação solar e, consequentemente, aumento da temperatura e déficit e saturação do ar, além da estufa permanecer mais tempo aberta para ventilação, associada ao concomitante crescimento das plantas (Dalsasso, 1997; Caron, 1999; Valandro, 1999). 


\section{MATERIAL E MÉTODOS}

\subsection{Local do experimento}

O experimento foi realizado no período de 27 de fevereiro a 5 de julho de 1999, no interior de uma estufa plástica localizada no Campo Experimental do Departamento de Fitotecnia do Centro de Ciências Rurais da Universidade Federal de Santa Maria - UFSM ( $29^{\circ} 42^{\prime} \mathrm{S}, 53^{\circ} 42^{\prime} \mathrm{W}$ e $95 \mathrm{~m}$ de altitude), no Estado Rio Grande do Sul. O clima da região, conforme a classificação de Köppen, é Cfa, clima subtropical úmido sem estação seca definida. As temperaturas médias do mês mais frio (junho) e do mais quente (janeiro) são, respectivamente, 12,9 e $24,6{ }^{\circ} \mathrm{C}$.

A estufa utilizada possuía $10 \mathrm{~m} \times 24 \mathrm{~m}$, orientada no sentido norte-sul, com $3 \mathrm{~m}$ de altura na cumeeira e $2 \mathrm{~m}$ de pé-direito em estrutura de madeira coberta com filme de polietileno de baixa densidade (PEBD) de $100 \mu \mathrm{m}$ de espessura. A Figura 1 mostra um esquema simplificado da mesma.

$O$ ambiente interno à estufa foi ventilado naturalmente pelas janelas laterais de $1 \mathrm{~m}$ de altura iniciando à $1 \mathrm{~m}$ do solo ao longo de toda a estufa, e portas frontais de $3 \mathrm{~m}$ de largura por $2 \mathrm{~m}$ de altura. O manejo das mesmas foi manual. Normalmente, realizou-se a abertura das portas frontais e cortinas laterais entre 8 e 9 horas da manhã. Nos dias de nevoeiro, a estufa foi aberta após a dissipação do mesmo. Quando ocorriam ventos fortes, precipitação, temperaturas baixas e/ou o dia mantinha-se encoberto, a estufa foi mantida fechada.

O fechamento da estufa, no início do experimento, quando havia maior disponibilidade de radiação solar (fevereiro-abril), era realizado em torno das $18 \mathrm{~h}$. Com a diminuição da duração dos dias e a conseqüente redução das temperaturas, passou a realizar-se mais cedo, para possibilitar um maior armazenamento de calor, sendo que, a partir do mês de maio, era fechada normalmente em torno das $16 \mathrm{~h}$. 


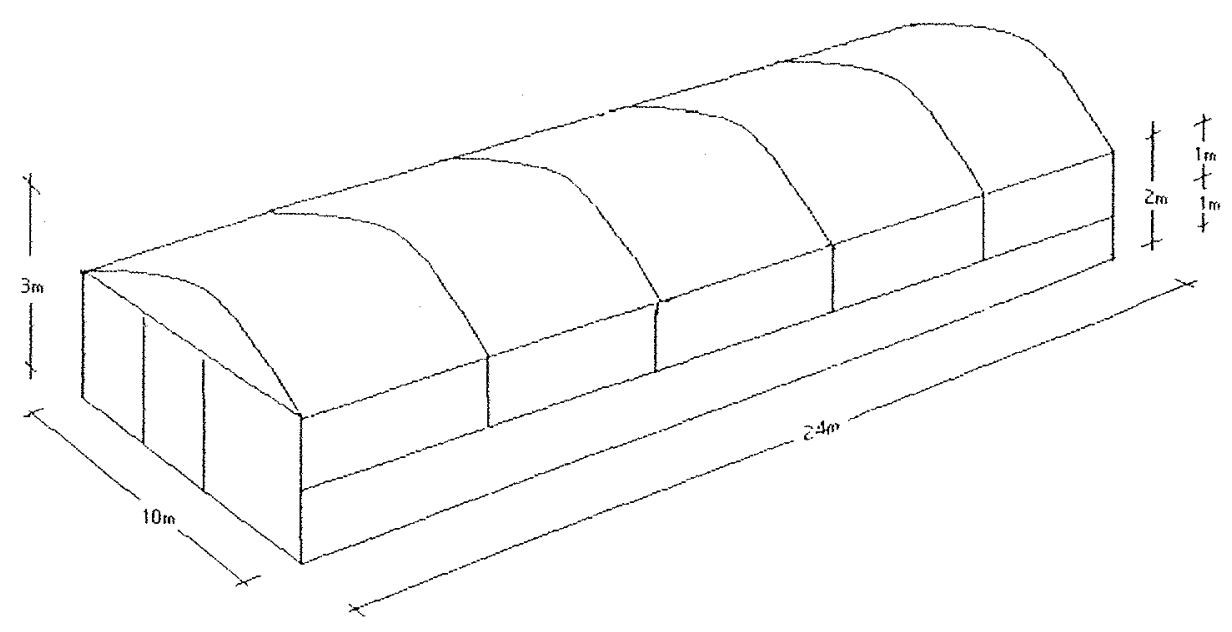

Figura 1: Esquema da estrutura da estufa utilizada no experimento.

\subsection{Condução do experimento}

As plantas de tomateiro, cultivar Imperror, foram cultivadas em 10 fileiras dispostas no sentido do comprimento da estufa, numa densidade de três plantas por metro quadrado. Aquelas plantas utilizadas no experimento foram conduzidas em 8 litros de substrato comercial (Plantmax), com capacidade de retenção d'água de 2,5 litros (Valandro, 1999), em sacolas plásticas perfuradas na sua parte inferior, para permitir a drenagem do excesso da água ou solução nutritiva da irrigação, envoltas por um filme plástico de cor preta para evitar a evaporação direta do substrato e formação de algas.

Foram conduzidas 15 plantas em três lisímetros coletores de drenagem, com cinco plantas cada, instalados nas três fileiras centrais do lado oeste da estufa. Além das plantas dos lisímetros, outras 68 foram cultivadas no mesmo tipo e na mesma quantidade de substrato na fileira central do lado oeste da estufa para eventual necessidade de substituição de alguma planta e para determinar a equação de estimativa 
da área foliar $(A F)$ nas plantas dos lisímetros, sendo necessário a utilização de método destrutivo.

A nutrição destas plantas foi realizada por meio de fertirrigação, com periodicidade semanal, cuja formulação utilizada consta da tabela 1 .

A semeadura foi realizada no dia 1 de Fevereiro e no dia 23 do mesmo mês as mudas foram transplantadas no solo da estufa, e no dia 27 , nos lisímetros e na fileira com substrato.

No dia 15 de março foram substituídas três plantas no lisímetro 1 e 2 , e quatro plantas no lisímetro 3 por apresentarem problemas de estabelecimento. No dia 3 de abril mais duas plantas com problemas fitossanitários foram substituídas no lisímetro 1.

A condução das plantas foi em haste única suspensa por um fio de ráfia preso em arame à aproximadamente $2 \mathrm{~m}$ de altura. Em função da cultivar utilizada ser de hábito de crescimento determinado, em que a haste que emite as inflorescências encerra o seu crescimento, o primeiro broto abaixo das mesmas não foi retirado, formando a haste principal. Devido às plantas emitirem até quatro inflorescências por ramo, para que estes não se rompessem com o peso dos frutos e para obter-se melhor qualidade dos mesmos, deixou-se apenas duas inflorescências por ramo.

Tabela 1: Quantidade de fertilizante aplicado semanalmente por planta e para as 15 plantas dos lisímetros.

\begin{tabular}{lcc}
\multicolumn{1}{c}{ Fonte } & 1 planta & 15 plantas dos lisímetros \\
Nitrato de Potássio $\left(\mathrm{KNO}_{3}\right)$ & $4,1 \mathrm{~g}$ & $61,5 \mathrm{~g}$ \\
Nitrato de Cálcio $\left(\mathrm{Ca}\left(\mathrm{NO}_{3}\right)_{2}\right)$ & $6,3 \mathrm{~g}$ & $94,5 \mathrm{~g}$ \\
Super Simples $\left(\mathrm{P}_{2} \mathrm{O}_{5}\right)$ & $1,5 \mathrm{~g}$ & $22,5 \mathrm{~g}$ \\
Sulfato de Magnésio $\left(\mathrm{MgSO}_{4}\right)$ & $3,0 \mathrm{~g}$ & $45,0 \mathrm{~g}$ \\
Sol. Micronutrientes & $0,7 \mathrm{ml}$ & $10,5 \mathrm{ml}$ \\
Quelato de Ferro & $0,13 \mathrm{ml}$ & $2,0 \mathrm{ml}$ \\
\hline
\end{tabular}

Fonte: Andriolo \& Poerschke (1997) 
Nas outras 9 fileiras, as plantas foram cultivadas diretamente no solo para servir de bordadura. O solo foi adubado por ocasião do seu preparo com base em sua análise laboratorial. O seu preparo constou da passagem de enxada rotativa com microtrator. $\mathrm{O}$ adubo foi distribuído em uma faixa de aproximadamente $40 \mathrm{~cm}$ de largura onde foram construidos os camaleões para instalação das plantas. A condução destas plantas foi realizada da mesma forma que aquelas dos lisímetros.

A irrigação em todas as fileiras, exceto nos lisímetros, foi feita com mangueiras gotejadoras com orifícios distanciados $30 \mathrm{~cm}$ um do outro. No solo o controle da irrigação baseou-se no aspecto visual do mesmo, testando-se sua consistência em função da sua umidade através do tato.

As 68 plantas cultivadas em substrato na fileira central da estufa foram irrigadas diariamente, sendo que nos dias de maior demanda atmosférica, foram necessárias duas irrigações. A solução para fertirrigação destas plantas era preparada em um tambor de 60 litros instalado cerca de $2 \mathrm{~m}$ de altura do solo na extremidade mais elevada do terreno no interior da estufa.

Para aumentar a ventilação entre as plantas e eliminar possíveis fontes de inóculo de doenças foliares, no dia 3 de maio as folhas abaixo da primeira inflorescência foram retiradas por estarem em senescência.

Durante todo o período experimental monitorou-se o aspecto sanitário das plantas. Em intervalos de duas semanas aplicou-se fungicidas, alternando-se os produtos . comerciais Daconil e Ditane com Folicur para evitar o desenvolvimento de resistência pelos patógenos. Foram realizadas duas aplicações de Vertimec contra ácaros. Devido à carência dos agrotóxicos aplicados no tomateiro, encerrou-se sua aplicação uma semana antes de iniciar a comercialização dos frutos. garantindo sua qualidade alimentar. 


\subsection{Lisímetros}

Foram utilizados três lisímetros de drenagem instalados paralelamente nas três fileiras centrais do lado oeste da estufa, comportando cinco plantas em cada um.

Os lisímetros foram construídos com uma calha de PVC, posicionada sobre a superfície do solo com sua abertura voltada para cima, levemente inclinada para facilitar o escoamento da água, onde foram colocadas as embalagens com o substrato, cobertas com um filme plástico preto para impedir a evaporação direta e o estabelecimento de algas (Valandro, 1999) (Figura 2), sendo a perda do sistema somente pela transpiração das plantas. Na parte inferior interna da calha, colocou-se uma mangueira compacta sob as sacolas com substrato para que as mesmas não impedissem o escoamento da água.

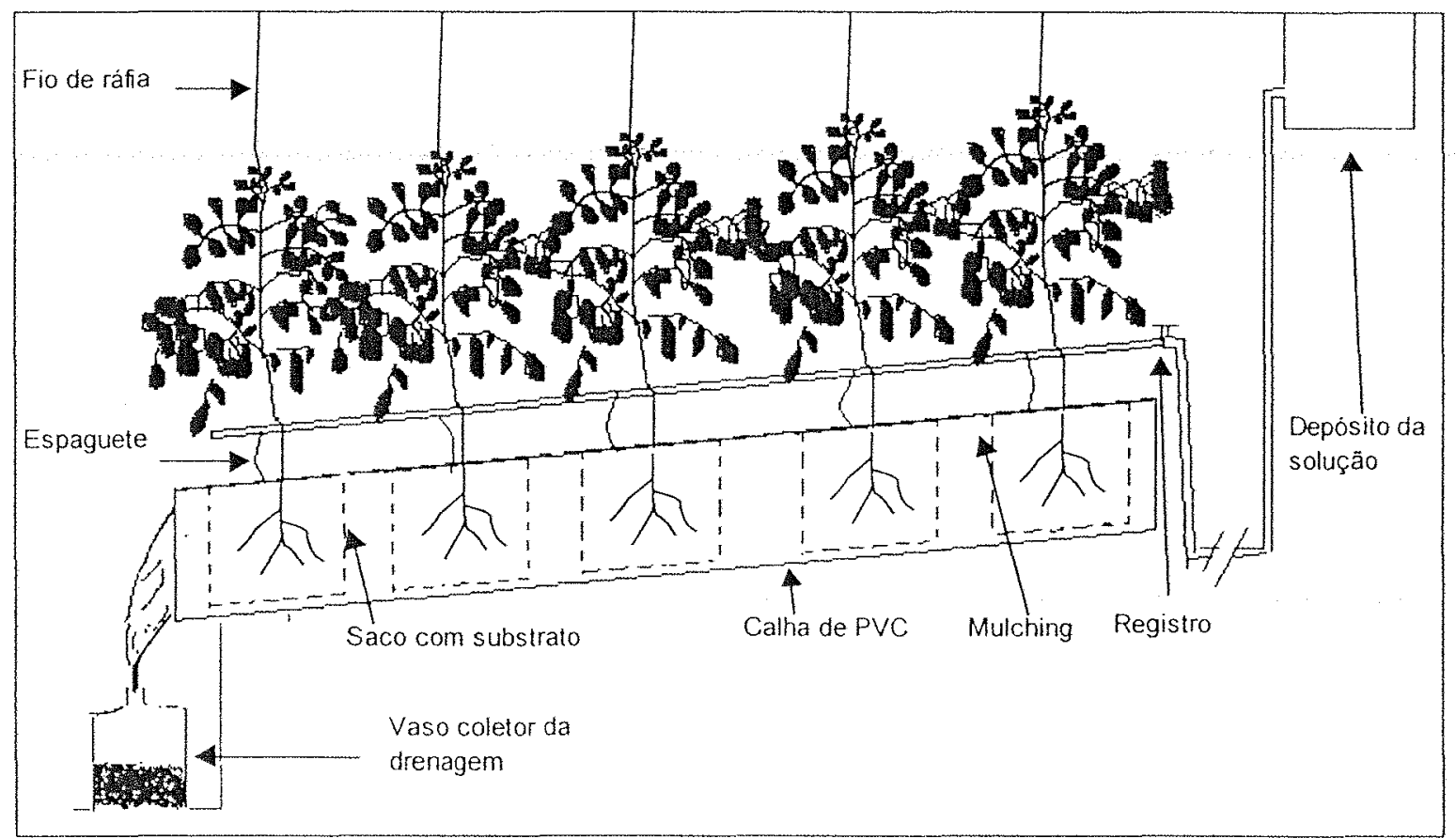

Figura 2: Esquematização do tipo de lisímetro utilizado no experimento.

Os lisímetros eram conectados por um sistema hidráulico a um tanque graduado com diâmetro de $24,5 \mathrm{~cm}$ e capacidade de aproximadamente 32 litros, instalado a $1,5 \mathrm{~m}$ do solo, distante $0,5 \mathrm{~m}$ da primeira fileira de plantas. Cada planta recebeu a 
solução diretamente no substrato por meio de um espaguete de aproximadamente $2 \mathrm{~mm}$ de diâmetro. A adubação das plantas também foi por meio de fertirrigação conforme a Tabela 1.

Cada lisímetro foi irrigado independentemente. Isto foi possível pela utilização de registros individuais. Enquanto era realizada a irrigação de um lisímetro, nos outros dois os registros eram mantidos fechados.

Da mesma forma que nas 68 plantas cultivadas em substrato na fileira central da estufa, naquelas dos lisímetros também realizaram-se irrigações diárias, sempre no início da manhã. Da mesma maneira, nos dias de alta demanda atmosférica, uma segunda irrigação foi necessária.

\subsection{Obtenção dos dados}

\subsubsection{Elementos meteorológicos}

A densidade de fluxo de radiação solar global incidente no exterior da estufa $\left(R g_{e}\right.$, em W m $\left.{ }^{-2}\right)$ foi estimada a partir de dados de insolação registrados na estação meteorológica localizada a cerca de $50 \mathrm{~m}$ ao sul da estufa, através da equação (Estefanel et al., 1990):

$$
R g_{e}=K \downarrow\left[b_{o}+b_{1}\left(\frac{n}{N}\right)\right]
$$

em que $K \downarrow$ é a densidade de fluxo de radiação solar incidente no topo da atmosfera (W $\mathrm{m}^{-2}$ ), $b_{0}$ e $b_{l}$ coeficientes mensais ajustados para Santa Maria, $n$ é a insolação (horas dia') e $N$ é o comprimento do dia (horas $\operatorname{dia}^{-1}$ ).

A temperatura $\left(t_{m i} \mathrm{em}{ }^{\circ} \mathrm{C}\right)$ e a umidade relativa $\left(U R_{m i}\right.$ em $\left.\%\right)$ médias diárias do ar no interior da estufa foram calculadas a partir dos registros de um termohigrógrafo instalado a $1,5 \mathrm{~m}$ do solo em abrigo padrão no centro da estufa. Para o cálculo das médias utilizou-se os valores de 2 em 2 horas. 
A temperatura $\left(t_{m e} \mathrm{em}{ }^{\circ} \mathrm{C}\right)$ e umidade relativa $\left(U R_{m e} \mathrm{em} \%\right)$ médias diárias do ar no exterior da estufa foram calculadas a partir das medidas realizadas na estação meteorológica, conforme as equações abaixo:

$$
\begin{aligned}
& t_{m l v}=\frac{t_{9}+2 . t_{2 I}+t_{c \max }+t_{c m i n}}{5} \\
& U R_{m e}=\frac{U R_{9}+U R_{15}+2 . U R_{2 I}}{4}
\end{aligned}
$$

em que $t_{9}, t_{2 l}, t_{e m a x}$ e $t_{e m i n}$ são, respectivamente, as temperaturas medidas às 9 e 21 horas, máxima e mínima diária, e $U R_{9}, U R_{15}$ e $U R_{21}$ são, respectivamente, a umidade relativa do ar medida às 9,15 e 21 horas.

O déficit de saturação do ar diário no interior da estufa $\left(D_{i} \mathrm{em} \mathrm{kPa}\right)$ foi calculado pela diferença entre a pressão de saturação do ar $\left(e_{s}\right)$ e a pressão parcial de vapor $\left(e_{a}\right)$ :

$$
\text { , } D_{i}=e_{s}-e_{a}
$$

em que $e_{s}$ foi obtido em $\mathrm{kPa}$ com a equação de Tetens (1930), considerando-se a temperatura média diária do ar no interior da estufa $\left(t_{m i} \mathrm{em}{ }^{\circ} \mathrm{C}\right)$ :

$$
e_{s}=0,61.10^{\left(\frac{7.5 t_{m i}}{2.37 .3+t_{m i}}\right)}
$$

$e_{a}(\mathrm{kPa})$ foi determinado a partir de $e_{s}$ e a umidade relativa média diária do ar no interior . da estufa $\left(U R_{m i}\right)$ :

$$
e_{a}=e_{s} \frac{U R_{m i}}{100}
$$

No cálculo do déficit de saturação do ar diário no exterior da estufa $\left(D_{e}\right)$, substituiu-se $t_{m i}$ na equação (13) e $U R_{m i}$ na equação (14) por $t_{m e}$ e $U R_{m e}$, respectivamente. O mesmo procedimento foi tomado no cálculo do déficit de saturação do ar máximo no interior da estufa $\left(D_{\text {max }}\right)$. utilizando-se a temperatura máxima do ar $\left(t_{\text {imax }}\right)$ e a umidade relativa do ar mínima $\left(U R_{i m i n}\right)$, diárias, e para o déficit de saturação do ar no exterior às 15 horas $\left(D_{e} 15\right)$, utilizando-se $t_{15} \mathrm{e} U R_{15}$, respectivamente. 


\subsubsection{Consumo hídrico do tomateiro}

O consumo d'água diário por planta (CONS em $\mathrm{kg}_{\text {planta }}{ }^{-1} \mathrm{dia}^{-1}$ ) foi calculado a partir dos dados obtidos dos 3 lisímetros pela diferença entre o volume irrigação $\left(I \mathrm{em} \mathrm{cm}^{3}\right)$ e o drenado $\left(D \mathrm{em} \mathrm{cm}^{3}\right)$ :

$$
\text { CONS }=\frac{\left(I_{L, 1}-D_{L, 1}\right) / 5+\left(I_{L, 2}-D_{L, 2}\right) / 5+\left(I_{L, 3}-D_{L 3}\right) / 5}{3.1000}
$$

em que $L 1, L 2$ e $L 3$ são, respectivamente, os lisímetros 1, 2 e 3, numerados no sentido leste-oeste, e 1000 é $\mathrm{um}$ fator de passagem de $\mathrm{cm}^{3}$ para $\mathrm{kg}$.

O volume de irrigação foi calculado pelo produto da área da superfície da

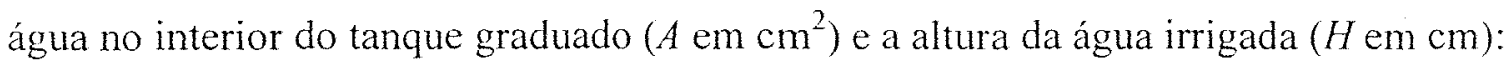

$$
I=A . H
$$

Cada lisímetro foi irrigado até 3 min depois de ter iniciado a drenagem e após o término da mesma mediu-se o volume drenado com uma proveta com capacidade

de $1000 \mathrm{~cm}^{3}$ e resolução de $10 \mathrm{~cm}^{3}$. O consumo foi contabilizado do início da manhã do dia em questão até o início da manhã do dia seguinte. Quando a realização de duas irrigações diárias, o volume irrigado e drenado da segunda irrigação diária foi somada àquela da manhã do dia seguinte.

\subsubsection{Variáveis de crescimento das plantas}

O número de folhas e altura foram determinados em todas as plantas dos lisímetros em intervalos de aproximadamente 7 dias. $\mathrm{Na}$ análise dos dados utilizou-se os valores médios de todas as plantas dos três lisímetros, NF e $A L T$, respectivamente para o número médio de folhas e altura média das plantas.

A determinação da área foliar $(A F)$ constou de duas etapas: (1) obtenção de uma equação estatística para estimar $A F$ e (2) estimativa da $A F$ nas plantas dos lisimetros pela equação obtida na primeira etapa.

1) Obtenção da equação: Semanalmente mediu-se o maior comprimento e a maior largura de cada folha e determinou-se o número de folhas, das plantas a serem 
destruídas. Após, retirou-se as plantas da estufa e separou-se o limbo foliar dos pecíolos, caules, inflorescências e frutos.

Foram retirados 80 discos de diâmetro de $9,1 \mathrm{~mm}$, do limbo de 20 folhas distribuídas na planta. A partir da terceira semana de abril as folhas das plantas foram separadas em dois extratos, inferior com as folhas mais velhas e superior com as folhas mais jovens, retirando-se 40 discos do limbo de dez folhas de cada estrato.

O limbo das folhas e os discos foram colocados em uma estufa de circulação de ar quente, a $40^{\circ} \mathrm{C}$, para secarem até peso constante, determinando-se a matéria seca dos discos e do limbo foliar, respectivamente, (MSd) e (MSf), em g.

A área foliar foi obtida com a seguinte equação:

$$
A F=\frac{M S f \cdot A d}{M S d}
$$

sendo $A d$ a área dos 80 discos retirados, $\mathrm{em} \mathrm{cm}^{2}$ :

$$
A d=80 \cdot\left(\frac{\pi \cdot d^{2}}{4}\right)=20 \cdot \pi \cdot d^{2}
$$

em que $d$ é $\mathrm{o}$ diâmetro do disco em $\mathrm{cm}$.

Com os valores da $A F$ destas plantas, obteve-se equações por regressões (forçando a passagem na intersecção dos dois eixos) com a soma do produto entre comprimento e largura das folhas de toda a planta $(C x L)$ e o número de folhas $(N F)$. Selecionou-se a equação (19) por apresentar o melhor coeficiente de determinação, $\mathrm{R}^{2}=0,86$ :

$$
A F=0,3676 . C x L
$$

Provavelmente, se comparado com métodos mais precisos que normalmente são destrutivos e mais trabalhosos, existe um erro relativamente elevado na estimativa por esta equação, visto a folha do tomateiro ser formada por folíolos, que normalmente são muito retorcidos, o que leva a erros nas medidas de suas dimensões. Em função do número limitado de plantas disponiveis para serem destruídas, não foi possível testar esta equação com dados independentes daqueles utilizados na sua determinação. 
2) Estimativa da $A F$ : Nas plantas 2 e 3 de cada lisímetro mediu-se semanalmente o comprimento e largura de cada folha, obtendo-se o $C x L$ da planta, o qual foi aplicado na Equação (19). Na análise dos dados, trabalhou-se com valores médios $\left(\mathrm{em} \mathrm{m}^{2}\right.$ ) das 6 plantas medidas. A primeira determinação ocorreu no dia 3 de março e a última no dia 5 de julho.

Os valores diários do $N F$, das $A L T$ e $A F$ entre as determinações a campo foram obtidos por interpolação dos dados.

\subsubsection{Resistência foliar à difusão de vapor}

A resistência foliar à difusão de vapor $\left(r_{s}\right.$, $\left.\mathrm{em} \mathrm{s} \mathrm{m}^{-1}\right)$ foi medida com o objetivo de verificar a resposta do tomateiro às variações ambientais, observando se as condições micrometeorológicas da estufa causaram estresse hídrico na cultura durante o experimento.

As medidas foram realizadas em uma planta de cada lisímetro utilizandose um porômetro de difusão de vapor de equilibrio dinâmico da LICOR, modelo LI1600. As determinações foram realizadas na face inferior de 8 folhas marcadas, nos dias 19 e 25 de março, 8, 14, 20 e 29 de abril e 3 de maio. A partir do dia 8 de abril as folhas dessas plantas foram dividas em 2 estratos, realizando-se, assim, medidas de resistência em 4 folhas no estrato superior e 4 no estrato inferior, separando-se na análise dos dados as folhas mais jovens e ensolaradas das mais velhas.

Foram determinadas, também, com o auxilio do mesmo aparelho, a densidade de fluxo de fótons fotossinteticamente ativos (DFFA, em $\mu \mathrm{mol} \mathrm{m} \mathrm{m}^{-2} \mathrm{~s}^{-1}$ ) na folha, a temperatura da folha $\left(t_{f}\right.$, em $\left.{ }^{\circ} \mathrm{C}\right)$ e a transpiração $\left(T R, \mathrm{em} \mu \mathrm{g} \mathrm{cm}{ }^{-2} \mathrm{~s}^{-1}\right)$.

Para a análise dos dados, utilizou-se as médias das séries de 24 determinações, 12 de cada estrato das plantas ( 4 folhas medidas por estrato de cada planta), relacionando-as com a $D F F A, t_{f}$ e as demais variáveis meteorológicas (umidade relativa do ar, déficit de saturação de vapor do ar $\left(D_{i}\right)$ e folha-ar $\left(D_{f}\right)$ e temperatura do ar $\left(T, e m{ }^{\circ} \mathrm{C}\right)$ ) correspondentes ao tempo de duração da série das medidas de $r_{s}$ utilizadas. Os valores de temperatura e umidade relativa do ar ambiente correspondentes ao período 
de cada série de medida de $r_{s}$ foram obtidos dos gráficos do termohigrógrafo. O déficit de saturação do ar foi calculado a partir dos valores de temperatura e umidade relativa do ar conforme descrito no item 3.4.1, equações (12), (13) e (14). O cálculo do déficit de saturação folha-ar seguiu a mesma metodologia do cálculo do déficit de saturação do ar. porém, utilizando-se a pressão de saturação na folha calculada pela equação de Tetens (1930) em função da sua temperatura.

\subsection{Razão entre consumo d'água e evapotranspiração de referência (TR/ETo)}

Obteve-se o consumo d'água diário por metro quadrado de solo $(T R$, em $\mathrm{kg} \mathrm{m}^{-2}$ de solo dia ${ }^{-1}$ ou $\mathrm{mm}$ dia $\left.^{-1}\right)$, para parametrizar com a evapotranspiração de refer6encia, foi obtida multiplicando-se CONS por 3. devido a densidade utilizada ser 3 . plantas por metro quadrado.

A ETo ( $\mathrm{mm} \mathrm{dia}{ }^{-1}$ ) foi calculada com os dados obtidos na estação meteorológica, com a equação (20) (Pereira et al., 1997), considerando-se o fluxo de calor no solo igual a zero $(G=0)$, devido sua variação diária não ser significativa:

$$
E T o=\frac{\Delta}{\Delta+\gamma^{*}}\left(R n_{c}-G\right) \frac{1}{\lambda}+\frac{\gamma .900}{(\Delta+\gamma)\left(t_{m c}+275\right)} U_{2} . D_{c}
$$

em que $\Delta$ é a declividade da curva de pressão de saturação (Equação 21), $\gamma$ é a constante psicrométrica $\left(\gamma=0,0622 \mathrm{kPa}^{\circ} \mathrm{C}^{-1}\right), \gamma^{*}$ é a constante psicrométrica modificada $\left(\mathrm{kPa}^{\circ} \mathrm{C}^{-1}\right)$ (Equação 22), $R n_{e}$ é a radiação líquida no exterior da estufa ( $\mathrm{MJ} \mathrm{m}^{-2}$ dia $^{-1}$ ), $\lambda$ é o calor latente de evaporação $\left(2,45 \mathrm{MJ} \mathrm{kg}^{-1}\right)$ e $U_{2}$ a velocidade média diária do vento a $2 \mathrm{~m}$ de altura na estação meteorológica $\left(\mathrm{m} \mathrm{s}^{-1}\right)$ :

$$
\begin{aligned}
\Delta & =\frac{4908 \cdot e_{s}\left(t_{m c}\right)}{\left(t_{m e}+237 \cdot 3\right)^{2}} \\
\gamma^{*} & =\gamma\left(1+0,33 \cdot U_{2}\right)
\end{aligned}
$$

A $R n_{e}$ foi calculada pela diferença entre o saldo de radiação de ondas curtas $(O C)$, considerando-se o coeficiente de refletividade para um gramado $(r=0,24)$, e 
o saldo de radiação de ondas longas $(O L)$ com o uso da equação adaptada por Doorembos \& Pruitt (1975) para clima úmido:

$$
\begin{aligned}
& O C=R g_{e}(1-r) \\
& O L=-\left(0,9 \frac{n}{N}+0,1\right)\left(0,56-0,25 \sqrt{e_{u k}}\right) \sigma \cdot T_{m e^{4}}{ }^{4} \\
& R n_{e}=O C-O L
\end{aligned}
$$

em que $e_{a e}$ a pressão atual de vapor ( $\mathrm{kPa}$ ) no exterior da estufa obtido em função de $t_{m e} \mathrm{e}$ $U R_{m e}, \sigma$ é a constante de Stefan-Boltzmann $\left(4,903.10^{-9} \mathrm{MJ} \mathrm{m}^{-2} \mathrm{~K}^{-1} \mathrm{dia}^{-1}\right)$, e $T_{m e}$ é a temperatura média diária do ar no exterior da estufa em $\mathrm{K}$.

\subsection{Análise dos dados}

Para estudar o efeito isolado das variáveis meteorológicas sobre o consumo d'água, determinou-se o consumo por unidade de área foliar (CONSf em $\mathrm{kg} \mathrm{m}^{-}$ ${ }^{2} \mathrm{dia}^{-1}$ ), conforme a equação:

$$
\text { CONSf }=\frac{\text { CONS }}{A F}
$$

Foram realizadas correlações entre o CONSf com as variáveis meteorológicas individualmente em planilhas do programa computacional Excel ${ }^{\mathbb{R}}$.

Equações de ajuste por meio de regressões múltiplas foram obtidas pelo procedimento "stepwise" (passo a passo), que seleciona as variáveis mais significativas, com auxílio do programa computacional Statistical Analyses Systens (SAS), considerando-se as variáveis meteorológicas concomitantemente.

Tanto para as correlações simples como as múltiplas, foram calculados os coeficientes de determinação $\left(\mathrm{R}^{2}\right)$.

Em função dos problemas de estabelecimento das plantas no início do experimento, na análise dos dados considerou-se apenas o período compreendido entre 18 de março e 4 de julho. 


\section{RESULTADOS E DISCUSSÃO}

\subsection{Produção e fenologia das plantas}

Durante todo o experimento, as plantas foram conduzidas sob condições hídricas e nutricionais ótimas, sendo, desta forma, o seu crescimento e desenvolvimento influenciados somente pela variação ambiental ou em função de doenças.

A primeira inflorescência ocorreu em $50 \%$ das plantas dos lisímetros no dia 23 de março, 24 dias após o transplante. No dia 4 de abril houve um alto índice de aborto de flores em função da temperatura do ar ter atingido $46^{\circ} \mathrm{C}$. Para o tomateiro, temperaturas acima de $35^{\circ} \mathrm{C}$ causam danos nas flores (Chamarro Lapuerta, 1995). No . final do experimento, as plantas encontravam-se com média de sete inflorescências.

Cada planta conduzida nos lisímetros produziu em média 19 frutos, que pesaram $3,18 \mathrm{~kg}$. Se considerada a área da estufa de $240 \mathrm{~m}^{2}$ e uma densidade de 3 plantas $\mathrm{m}^{-2}$, resultando num total de 720 plantas, a produção na estufa foi de 2,3ton. Estes dados são referentes somente aos frutos classificados como comercializáveis.

\subsection{Monitoramento das condições hídricas nas plantas}

Durante a condução do experimento, o período entre março e maio apresentou condições mais propícias para a ocorrência de estresse hídrico e térmico nas plantas, quando foram registrados os valores mais elevados de temperatura e déficit de saturação do ar. Do dia 18 de março até 4 de julho, a temperatura máxima absoluta do ar no interior da estufa $\left(46^{\circ} \mathrm{C}\right)$, ocorreu no dia 4 de abril. Este valor elevado ocorreu em função do retardamento da abertura das janelas laterais e portas frontais para ventilação 
após a dissipação do nevoeiro, o que causou murchamento das plantas detectado visualmente. $\mathrm{Na}$ análise dos dados, os dias 3 e 4 de abril foram desconsiderados em função da realização da irrigação e drenagem às 15 horas no dia 4 de abril e não no início da manhã, o que superestimou o consumo no dia 3 e subestimou no dia 4 . No restante do período, a temperatura máxima foi de $42^{\circ} \mathrm{C}$.

A Figura 3 apresenta a resistência média das folhas à difusão de vapor $\left(r_{s}\right)$ e a densidade de fluxo de fótons fotossinteticamente ativos ( $D F F A$ ) determinados nos dias 19 e 25 de março, 8, 14, 20 e 29 de abril e 3 de maio. Observa-se que durante o período experimental ocorreu uma redução dos níveis de $D F F A$ em função da maior inclinação dos raios solares, redução do comprimento dos dias e, também, pela menor penetração da radiação no estrato inferior das folhas.

Durante o período do dia de maior incidência de radiação solar, $r_{s}$ atingiu os menores valores diários, mantendo-se em torno de $150 \mathrm{~s} \mathrm{~m}^{-1}$ para valores de $D F F A$ superiores a aproximadamente $200 \mu \mathrm{mol} \mathrm{m}^{-2} \mathrm{~s}^{-1}$. Estes valores são similares àqueles utilizados por Chalabi \& Bailey (1989) e Aikman \& Houter (1990) citados por Jolliet \& Bailey (1992), que consideraram valores fixos da resistência estomática para a estimativa da transpiração do tomateiro em estufa, considerando para o período diurno $200 \mathrm{~s} \mathrm{~m}^{-1}$, e para o noturno 3300 $\mathrm{s} \mathrm{m}^{-1}$ (Chalabi \& Bailey, 1989) e 2000s $\mathrm{m}^{-1}$ (Aikman \& Houter, 1990).

No dia 25 de março, quando a temperatura do ar no interior da estufa alcançou $39^{\circ} \mathrm{C}$, não foi detectado aumento da $r_{s}$ que não tenha sido em função da redução dos níveis de DFFA.

Outro indicador de um possível estresse hídrico das plantas que se pode considerar é a diferença entre a temperatura das folhas e do ar $\left(t_{\digamma} T\right)$. A Figura 4 ilustra sua variação diária, onde nota-se que em nenhum momento, nos dias de medida, a temperatura das folhas $\left(t_{f}\right)$ foi superior à temperatura do ar no interior da estufa. Com isto, infere-se que na maioria dos dias os picos de transpiração das plantas não originaram um déficit hídrico capaz de causar danos ou efeito sobre a produção, e a $t_{f}$ não atingiu valores suficientemente elevados que resultasse em restrição da transpiração 

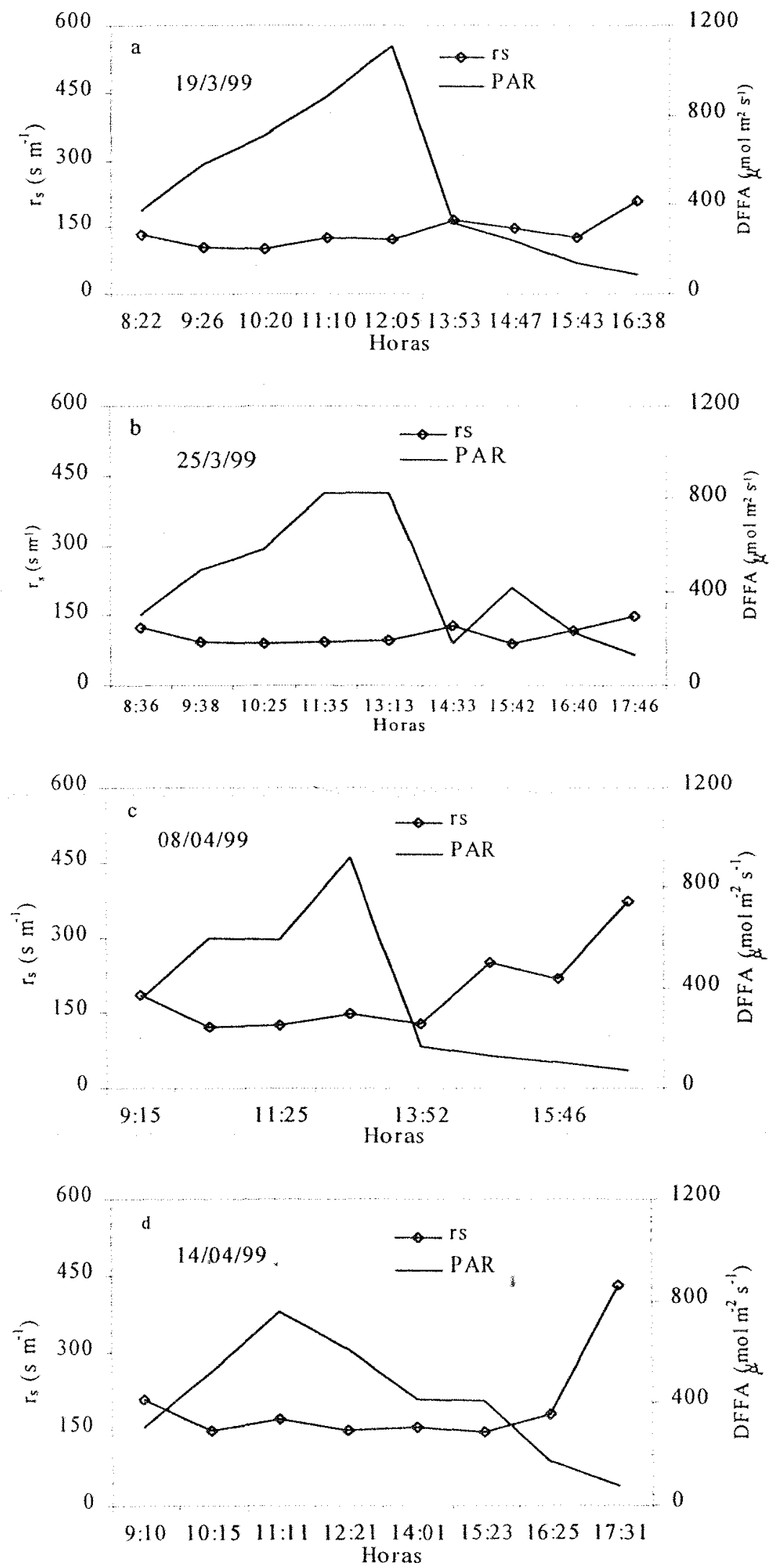

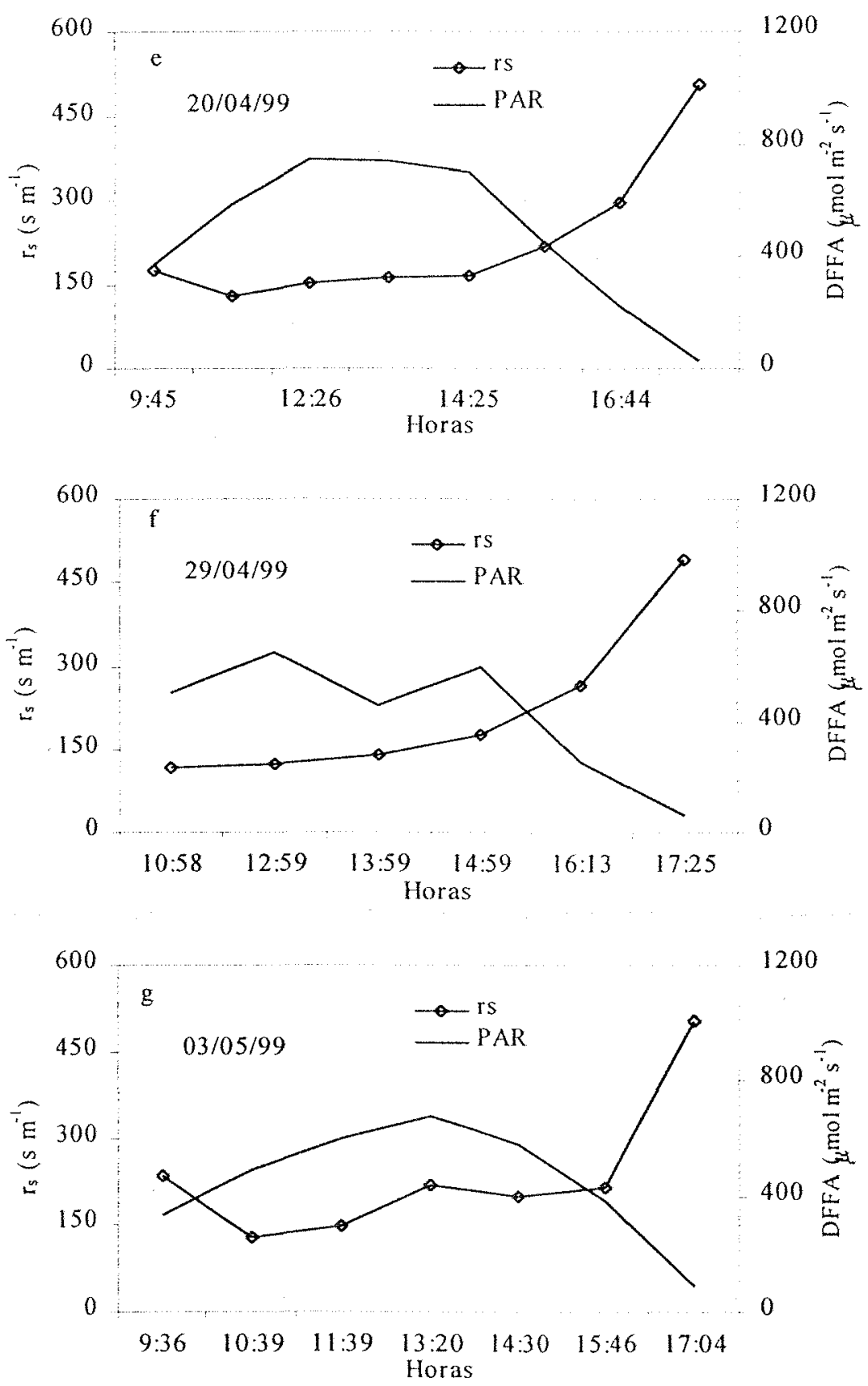

Figura 3: Resistência média das folhas à difusão de vapor $\left(r_{s}\right)$ e da densidade de fluxo fótons fotossinteticamente ativos ( $D F F A$ ) incidente nas folhas para os dias: 19/03/99 (a), 25/03/99 (b), 08/04/99 (c), 14/04/99 (d), 20/04/99 (e), 29/04/99 (f) e 03/05/99 (g). Santa Maria, RS. 
por fechamento estomático durante o período experimental, visto terem sido conduzidas . sob condições hídricas ótimas.

A DFFA foi a única variável meteorológica a correlacionar-se com $r_{s}$, $\mathrm{R}^{2}=0,54$, Figura 5. Como era de se esperar, o aumento da DFFA resultou na redução da $r_{s}$ (Rutter, 1975). O melhor ajuste foi obtido com uma curva logaritmica $\left(r_{s}=a+\right.$ b. $\ln (D F F A)$ ). Boulard et al. (1992) encontraram uma relação logarítmica da razão entre as resistências da superfície superior e inferior das folhas de tomateiro com a radiação solar. No entanto, Yang et al. (1990) encontrou uma relação exponencial da resistência estomática da cultura do pepineiro com a radiação solar.

A temperatura do ar e da folha e os déficit de saturação do ar e folha-ar não se correlacionaram $\operatorname{com} r_{s}$, porém, tiveram um efeito negativo.

Analisando-se somente os dados referentes à faixa de $D F F A \geq 600 \mu \mathrm{mol}$ $\mathrm{m}^{-2} \mathrm{~s}^{-1}$, não houve correlação de $r_{s}$ com as variáveis meteorológicas. Apenas no estrato superior das plantas notou-se tendência de $r_{s}$ em aumentar em função do aumento das variáveis meteorológicas, sendo importante ressaltar que esta análise ficou prejudicada em função de se ter poucos dados.

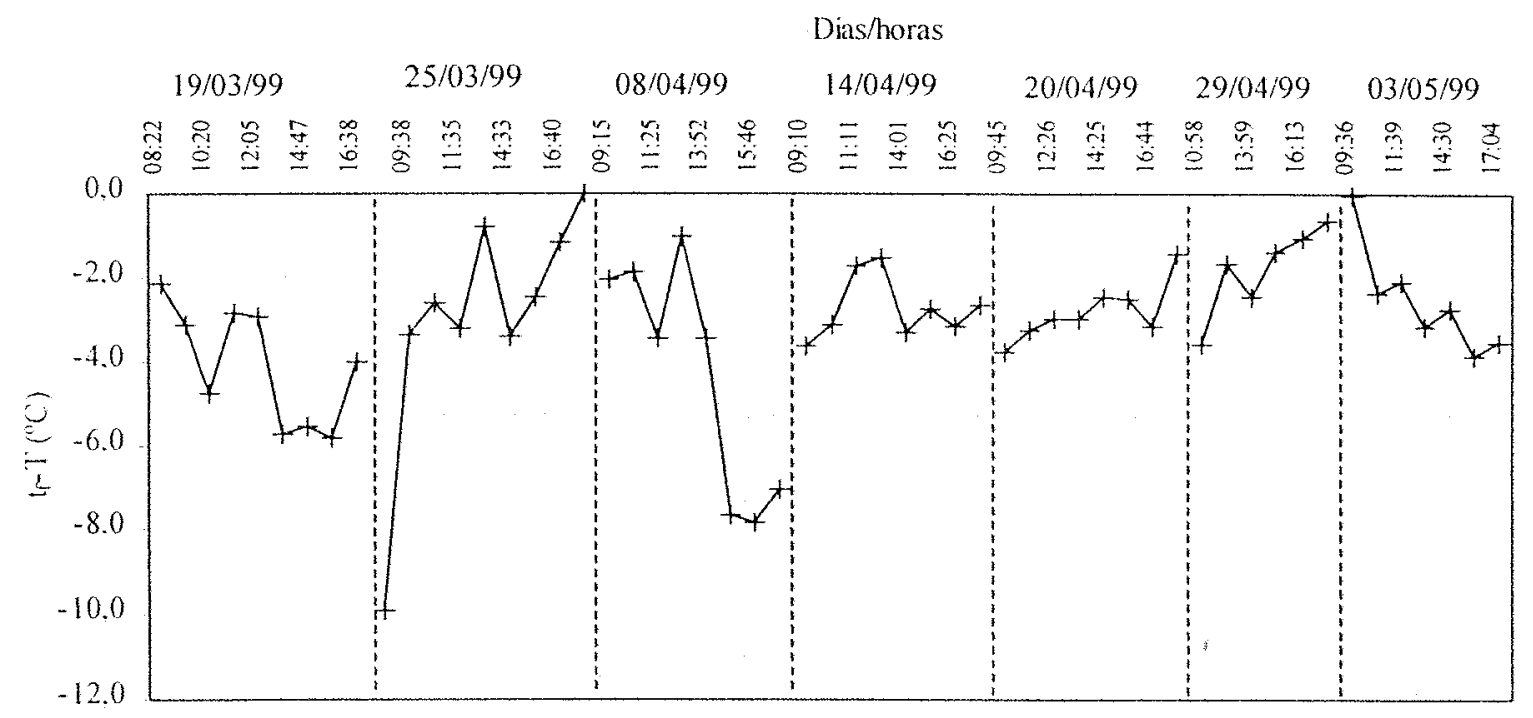

Figura 4: Variação diária da diferença entre a temperatura das folhas do tomateiro e a temperatura do ar $\left(t_{f}-1\right)$, médias de 24 medidas, nos dias 19 e 25 de março, 8 , 14,20 e 29 de abril e 3 de maio. Santa Maria, RS. 


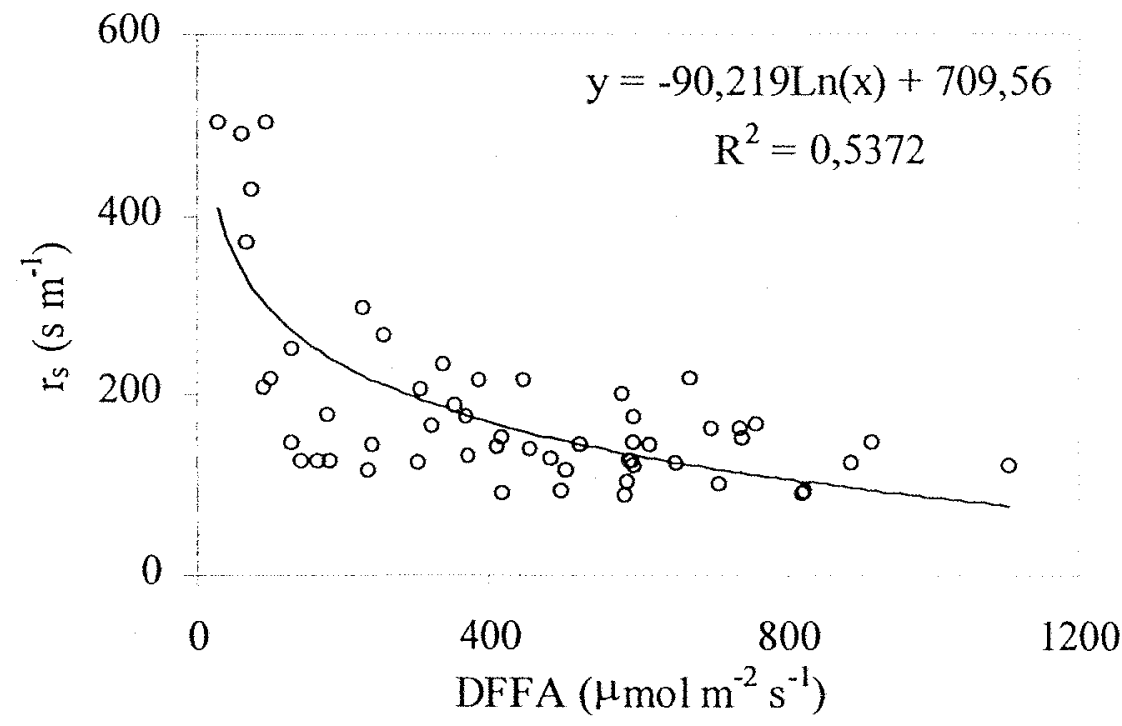

Figura 5: Correlação entre a resistência média das folhas à difusão de vapor $\left(r_{s}\right)$ e a densidade de fluxo de fótons fotossinteticamente ativos (DFFA). Santa Maria, RS.

Cabe ressaltar que não foram realizadas medidas da concentração de $\mathrm{CO}_{2}$ na atmosfera circundante à folha, mas Jolliet \& Bailey (1992) não encontraram efeito significativo deste fenômeno em tomateiro cultivado no interior de uma estufa.

\subsection{Consumo d'água, parâmetros de crescimento das plantas e variáveis meteorológicas}

Durante o experimento, ocorreu uma redução gradativa da densidade de fluxo de radiação solar global incidente no exterior da estufa $\left(R g_{e}\right)$ e, consequentemente, da radiação líquida $\left(R n_{e}\right)$ (Figura 6a), da temperatura média diária do ar no exterior $\left(t_{m e}\right)$ e no interior da mesma $\left(t_{m i}\right)$ (Figura $6 \mathrm{~b}$ ). Estas condições meteorológicas são consideradas normais para a época do ano, em função do aumento da inclinação dos raios solares em relação à superfície terrestre e diminuição do comprimento dos dias, além da maior freqüência de entradas de frentes frias e ocorrência de nevoeiros. (Estefanel et al., 1998). 
Durante todo o período experimental considerado (18/03/99 - 04/07/99) a temperatura média do ar no interior da estufa foi $4,1^{\circ} \mathrm{C}$ superior daquela do exterior. Este valor é diferente do obtido por Farias et al. (1993b) em Pelotas, RS, que encontraram uma diferença entre a temperatura média do ar no interior e exterior da estufa de $1,1^{\circ} \mathrm{C}$. . Isto deve-se, provavelmente, ao seu estudo ter sido realizado de setembro a janeiro, período em que a estufa é mantida mais tempo aberta para ventilação, além da sua estrutura e das condições ambientais do local do experimento serem diferentes.

$\mathrm{Na}$ Figura $6 \mathrm{~b}$ também pode ser observada uma forte relação entre $t_{m i}$ e $t_{m e}$, ambas apresentando praticamente a mesma flutuação, sendo que a primeira manteve-se sempre mais elevada. Esta similaridade da variação das temperaturas se deve à relativamente baixa freqüência de precipitações ocorridas durante o período experimental. Normalmente, a chuva causava uma redução da temperatura do ar no exterior da estufa, mas como nestas condições esta era mantida fechada, em seu interior a temperatura do ar mantinha-se mais elevada. Assim, a relação entre os valores internos e externos da estufa tende a diminuir com a ocorrência destes eventos.

O valor máximo da temperatura do ar no interior da estufa $\left(46^{\circ} \mathrm{C}\right)$ ocorreu no dia 4 de abril, causando murchamento das plantas, o qual foi descartado na análise dos dados pela medida do consumo d'água ter-se realizado às 15 horas e não no início da manhã. No restante do período, a máxima não passou de $42^{\circ} \mathrm{C}$. A mínima no interior da estufa ocorreu no dia 6 de junho, $5^{\circ} \mathrm{C}$, quando ocorreu também a mínima no exterior, $0,7^{\circ} \mathrm{C}$. A máxima no exterior da estufa $\left(35,6^{\circ}\right)$ ocorreu no dia 28 de março. $\mathrm{O}$ aumento da temperatura do ar observado no mês de junho se deve à entrada de uma frente quente (Figura 6b).

Em função da redução da densidade do fluxo de radiação solar global e da temperatura do ar, na Figura 7 observa-se uma tendência de aumento da umidade relativa média diária do ar no interior $\left(U R_{m i}\right)$ e no exterior $\left(U R_{m e}\right)$ da estufa e, consequentemente, redução do déficit de saturação do ar diário no interior $\left(D_{i}\right)$ e exterior $\left(D_{e}\right)$ da mesma. A redução do $D_{i}$ ocorreu, também, em função do aumento do tempo que a estufa permaneceu fechada para armazenar calor no seu interior no decorrer do período 

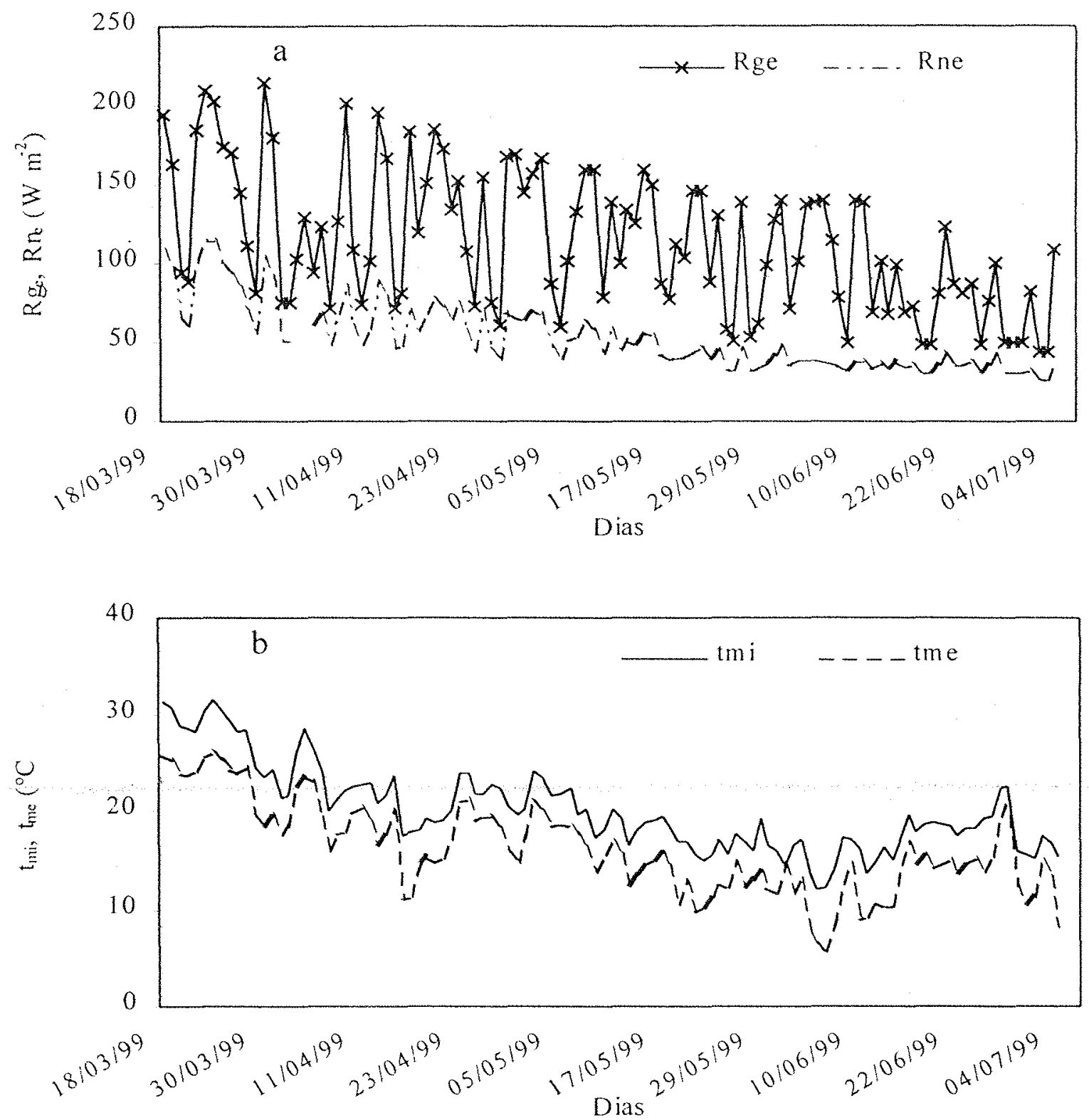

Figura 6: a) Densidade de fluxo de radiação solar global incidente $\left(R g_{e}\right)$ e a radiação líquida, no exterior da estufa $\left(R n_{e}\right)$; b) temperatura média diária do ar no interior $\left(t_{m i}\right)$ e exterior $\left(t_{m e}\right)$ da estufa. Período entre 18/03/99 a 04/07/99, Santa Maria, RS. 


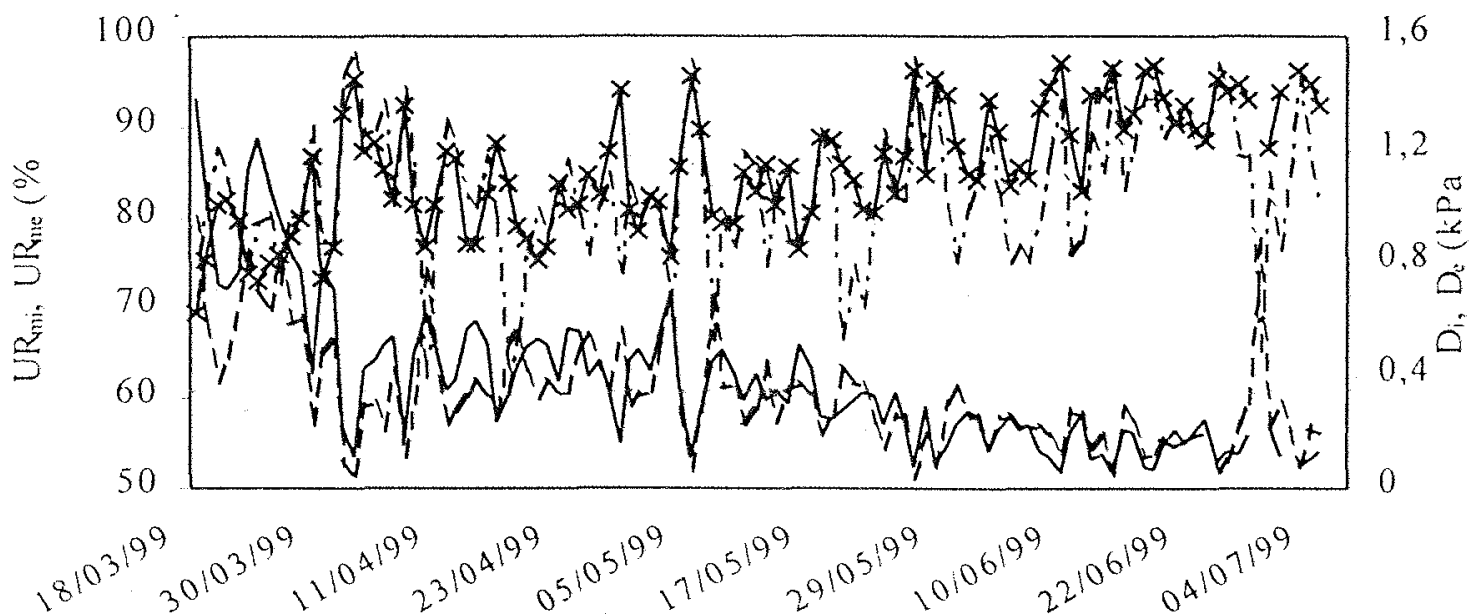

Dias

$\longrightarrow$ URmi $\ldots$. URme — Di $\quad \ldots \ldots$ De

Figura 7: Umidade relativa média diária do ar no interior $\left(U R_{m i}\right)$ e exterior $\left(U R_{m e}\right)$ da estufa e déficit de saturação do ar no interior $\left(D_{i}\right)$ e exterior $\left(D_{e}\right)$ da mesma. Período entre 18/03/99 e 04/07/99, Santa Maria, RS.

experimental, impedindo a dissipação do vapor d'água para o ambiente externo. O valor máximo ocorreu no dia 18 de março, 1,38kPa, e o mínimo no dia 9 de junho, 0,06kPa.

Enquanto as temperaturas médias internas e externas à estufa apresentaram praticamente a mesma tendencia de variação, isto não ocorreu com o déficit de saturação do ar no período experimental. Os valores médios de umidade relativa e déficit de saturação do ar no período foram, respectivamente, $86 \%$ contra $82,8 \%$, e $0,38 \mathrm{kPa}$ contra $0,33 \mathrm{kPa}$. Embora a umidade relativa média do ar do periodo no interior da estufa tenha sido 3,2\% maior do que a média externa, o déficit de saturação do ar foi $0,05 \mathrm{kPa}$ maior, resultado dos valores de $t_{m i}$ serem mais elevados que $t_{m e}$ e dos altos valores de $D_{i}$ em relação a $D_{e}$ observados no início do experimento, quando a área foliar das plantas era pequena.

As variáveis meteorológicas e de crescimento das plantas de tomateiro influenciaram fortemente o consumo d'água. Na Figura 8 a observa-se um leve aumento do consumo diário por planta (CONS) até meados de abril, período em que a demanda atmosférica ainda era alta, mas decrescente, e as plantas estavam em pleno crescimento, 
como mostra a evolução da área foliar média das plantas $(A F)$ (Figura 8a), e da altura média $(A L T)$ e número médio de folhas $(N F)$ por planta (Figura $8 \mathrm{~b}$ ), o que causou um . aumento da superfície transpirante. A diminuição do CONS do segundo decêndio de maio até o final do ciclo ocorreu em função da diminuição da demanda hídrica atmosférica $\left(D_{i}\right.$ e $D_{e}$, Figura 7) associada à estabilização do crescimento das plantas, principalmente $A F$, sendo que a partir do terceiro decêndio de maio esta sofreu uma leve redução causada pela desfolha e senescência das folhas. Ocorreu, também, um efeito da colheita dos frutos na diminuição do consumo d'água, a qual teve início no dia 14 de maio. Do dia 9 de junho até o final do experimento, nas plantas do lisímetro 3 todos os frutos foram eliminados e a transpiração foi $7 \%$ menor da média dos outros 2 .

O pico do consumo d'água ocorrido no dia 28 de junho se deve à entrada de uma frente quente e seca, o que provocou um aumento de $D_{e}$ (Figura 7) e possivelmente de $D_{i}$. A análise neste dia ficou comprometida em função de uma falha nos registros da umidade relativa do ar pelo termohigrógrafo.

$\mathrm{Na}$ Figura 8b, a queda brusca no número de folhas observado do dia 31 de maio para o dia 1 de junho se deve à retirada das folhas mais velhas, já em senescência, para eliminar possíveis fontes de inóculo de doenças e melhorar a ventilação no dossel das plantas.

O consumo d'água pelo tomateiro foi muito influenciado pela radiação solar como observa-se na Figura 9, na qual verifica-se que o CONS acompanhou a variação de $R g_{e}$. A radiação solar foi importante por seu efeito na regulação estomática e, também, ser a principal determinante da energia disponível para a transpiração das plantas.

O valor mais elevado de CONS (1,092 $\left.\mathrm{kg}_{\text {planta }}{ }^{-1} \mathrm{dia}^{-1}\right)$ ocorreu no dia 3 de maio, e o mínimo $\left(0,036 \mathrm{~kg}_{\text {planta }}{ }^{-1} \mathrm{dia}^{-1}\right)$ no dia 9 de março. Este último valor deve ser observado com ressalva porque nesta data as plantas que apresentavam problemas de estabelecimento ainda não haviam sido trocadas. Considerando-se somente os dias após a troca das plantas, o menor valor de CONS ocorreu no dia 3 de junho, sendo de $0,104 \mathrm{~kg}$ planta $^{-1} \mathrm{dia}^{-1}$. Durante todo o período experimental, 109 dias (18 de março a 4 de julho), ocorreu um consumo d'água de $52,73 \mathrm{~kg}$ planta $^{-1}$, perfazendo um consumo 


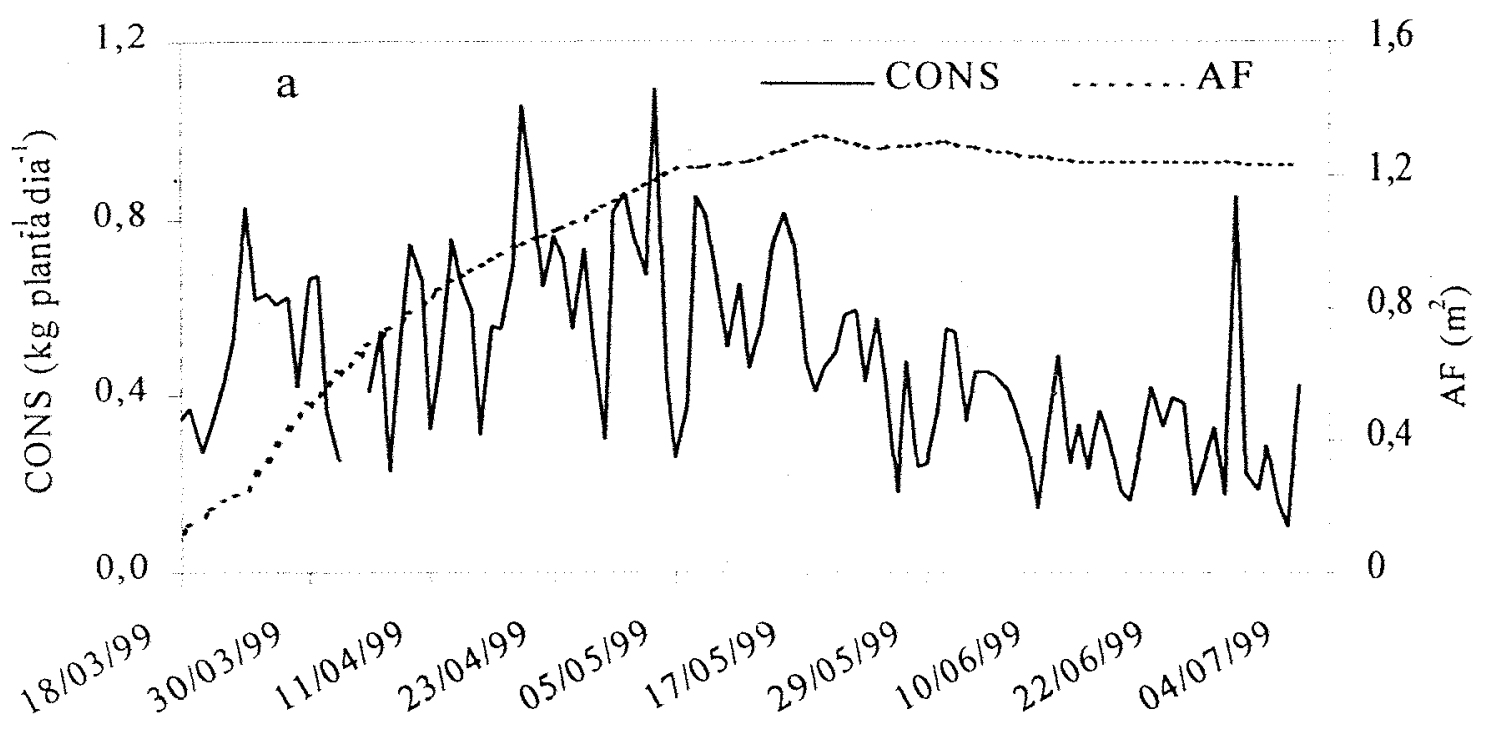

Dias

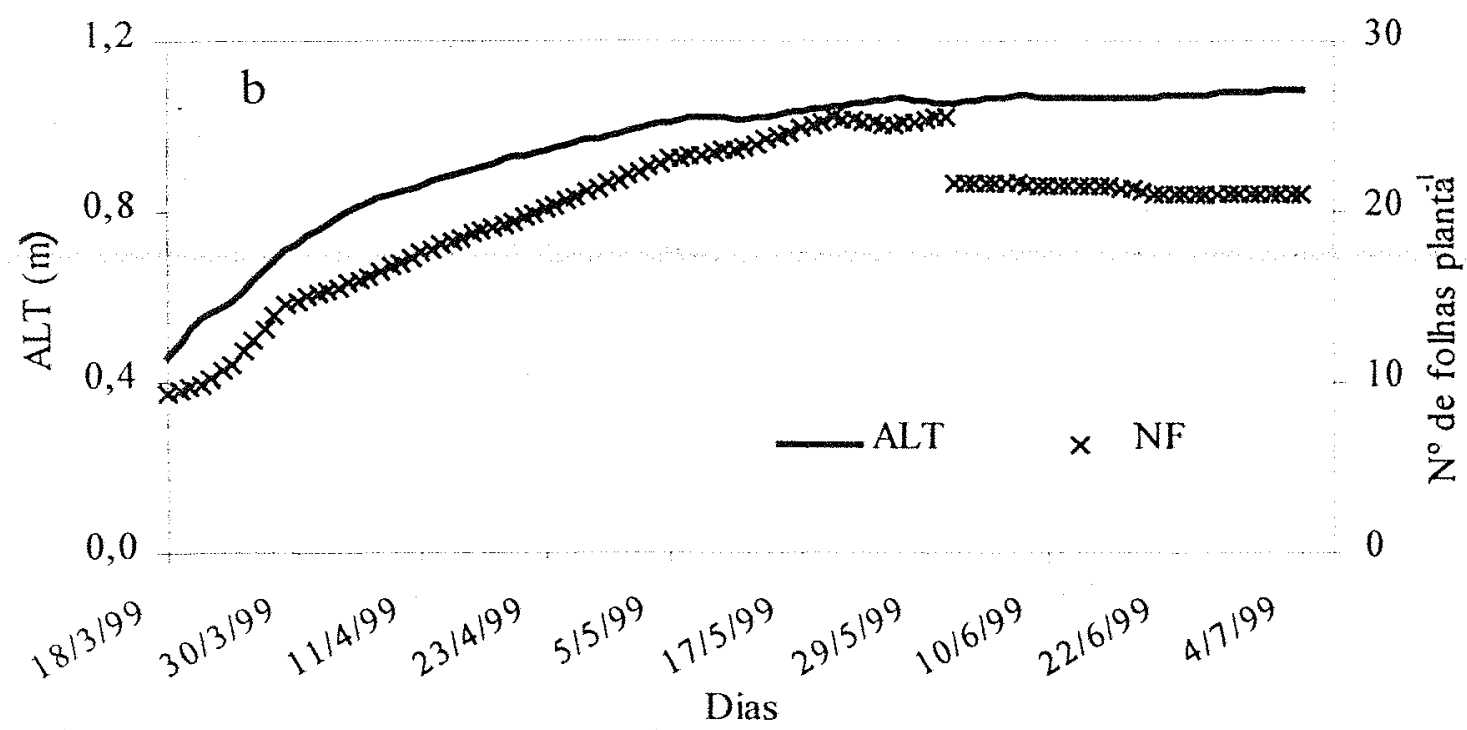

Figura 8: a) Consumo d'água diário por planta $(C O N S)$ e área foliar média das plantas $(A F)$; b) altura $(A L T)$ e número de folhas $(N F)$ médios por planta de tomateiro. Periodo entre 18/03/99 e 04/07/99, Santa Maria, RS. 


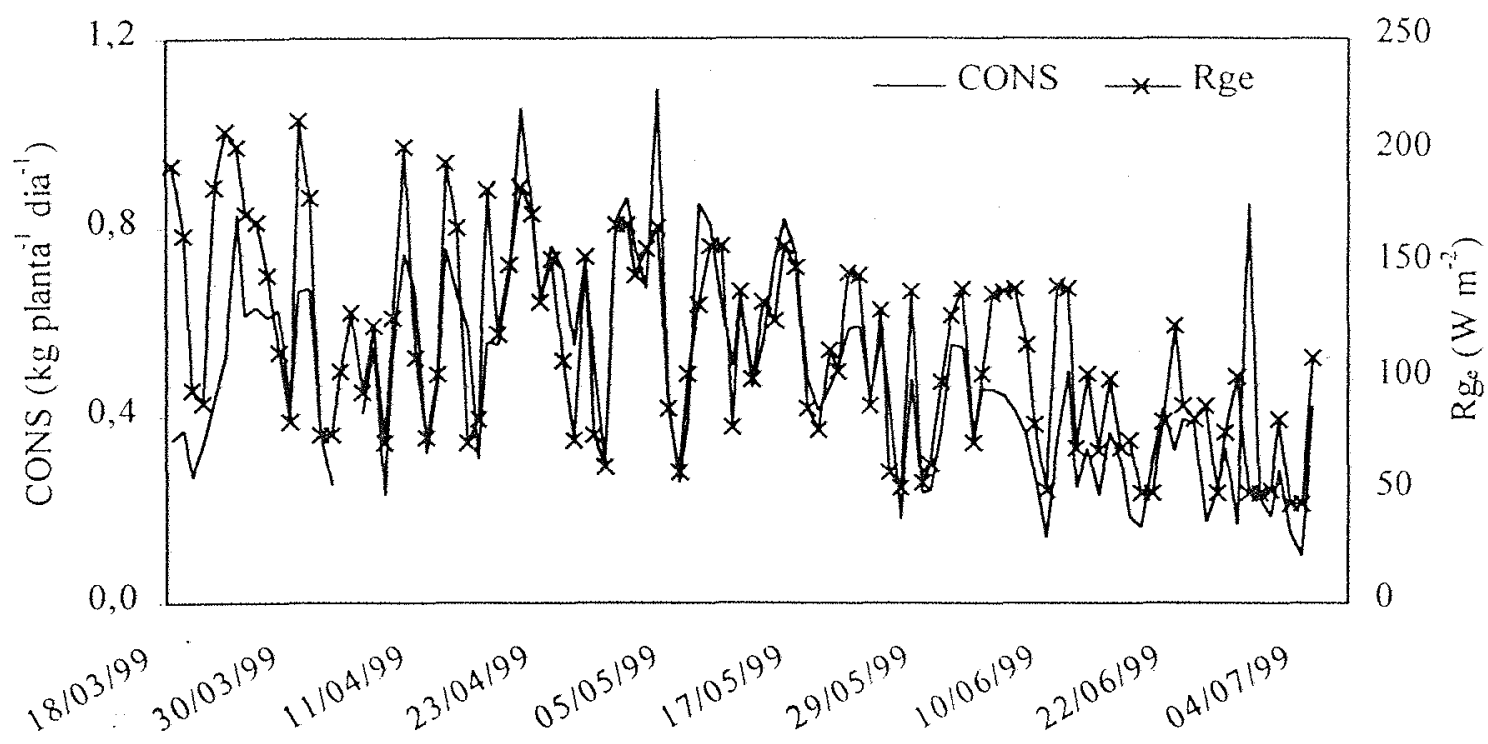

Dias

Figura 9: Consumo d'água diário por planta de tomateiro $(C O N S)$ e a densidade de fluxo de radiação solar global incidente no exterior da estufa $\left(R g_{e}\right)$. Período entre 18/03/99 e 04/07/99, Santa Maria, RS.

médio de $0,404 \mathrm{~kg}$ planta $^{-1}$ dia $^{-1}$, o qual foi inferior daquele encontrado por Valandro (1999), 0,516 $\mathrm{kg}_{\text {planta }}{ }^{-1} \mathrm{dia}^{-1}$, para a mesma época de cultivo, porém com uma cultivar de hábito de crescimento indeterminado e com condições climáticas diferentes. Deve-se ressaltar que este autor considerou somente os valores do consumo a partir da sétima semana após o transplante, num ciclo de 56 dias quando as plantas apresentavam uma área foliar elevada. Com tomateiro conduzido em solo, Dalsasso (1997) encontrou um consumo d'água de $0,387 \mathrm{~kg}$ planta $^{-1} \mathrm{dia}^{-1}$ para a mesma época de cultivo, praticamente 0 mesmo daquele encontrado neste trabalho.

O consumo d'água por unidade de área foliar (CONSf) foi decrescente durante praticamente todo o experimento, acompanhando com bastante afinidade as variações de $D_{i}$ (Figura 10). Isto se deve ao manejo das aberturas laterais e portas frontais da estufa, que dependeu das condições meteorológicas externas ocorridas durante o periodo experimental. Situações como um dia ensolarado, mas com temperatura do ar baixa no exterior da estufa, o que não permitiu a sua abertura para 
ventilação, acumulando o vapor d'água no seu interior, resultou em um $D_{i}$ baixo, limitando a transpiração, embora as condições de temperatura do ar no interior da estufa e radiação solar permitissem um elevado fluxo transpiratório. Outro motivo para o grande ajuste obtido entre CONSf e $D_{i}$, foi a freqüente entrada de frentes frias, que normalmente vem acompanhadas de nebulosidade e precipitação, obrigando o fechamento da estufa. Embora nestas condições a irradiância solar fosse baixa no exterior da estufa, no seu interior o déficit de saturação de vapor do ar ainda era elevado, proporcionando uma alta transpiração.

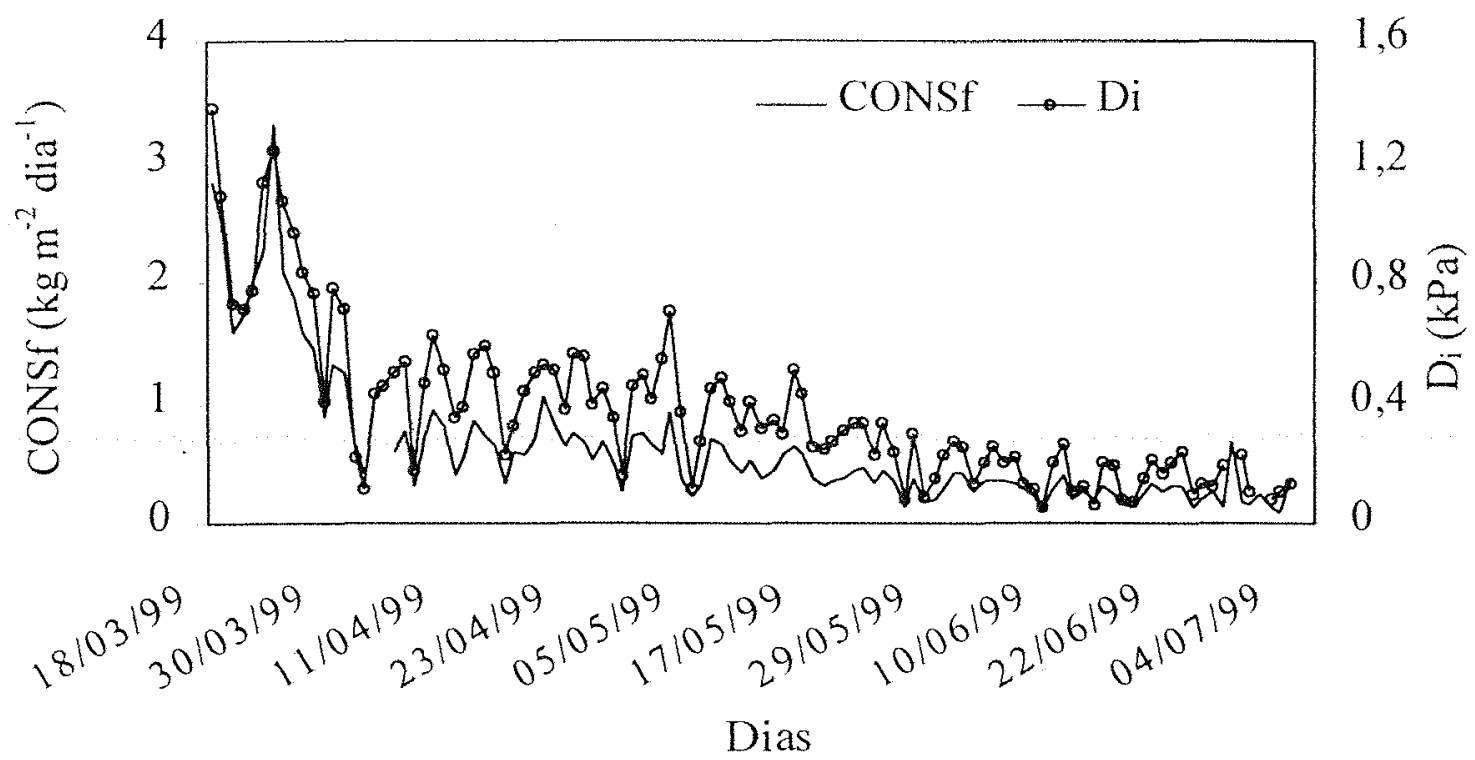

Figura 10: Consumo d'água diário por unidade de área foliar (CONSf) e déficit de saturação do ar diário no interior da estufa $\left(D_{i}\right)$. Período entre 18/03/99 e 04/07/99, Santa Maria, RS 


\subsection{Correlação entre o consumo d'água das plantas e as variáveis meteorológicas}

A densidade de fluxo de radiação solar global $\left(R g_{e}\right)$ teve um efeito diferenciado sobre o consumo d'água por unidade de área foliar (CONSf) conforme a gama de temperatura do ar no exterior da estufa (Figura 11). Para $t_{m e} \geq 20^{\circ} \mathrm{C}$, o coeficiente de determinação $\left(\mathrm{R}^{2}\right)$ foi bom, $\mathrm{R}^{2}=0,74$, enquanto que na faixa $15 \leq t_{m e}<20^{\circ} \mathrm{C}$, houve maior dispersão dos dados, $\mathrm{R}^{2}=0,64$; nestes dois casos uma função linear resultou em um ajuste melhor dos dados. Para $t_{m e}<15^{\circ} \mathrm{C}$, uma função potencial ajustou melhor os dados, $\operatorname{com} R^{2}=0,74$.

Em todas as faixas de temperatura a $R g_{e}$ teve um efeito positivo sobre CONSf, pois seu aumento causa a redução da resistência estomática nas folhas, até um determinado limite, e, normalmente, é acompanhado pelo aumento da temperatura e pelo déficit de saturação do ar, o que favorece a transpiração.

Estes valores dos coeficientes de determinação obtidos entre o consumo d'água e $R g_{e}$ foram superiores daqueles obtidos em experimentos anteriores em Santa Maria, para a mesma época do ano (Dalsasso, 1997 e Valandro, 1999). Porém, estes . autores não utilizaram CONSf, e sim o consumo diário por metro quadrado de área de solo (Dalsasso, 1997) e CONS (Valandro, 1999), ficando embutido o efeito da área foliar. Mas, os coeficientes de determinação obtidos no presente estudo são ainda bastante inferiores daqueles obtidos nas condições climáticas da Europa (De Villele, 1972; Stanhill, 1974; De Graaf \& Van Den Ende, 1981) e do Japão (Okuya \& Okuya, 1988), onde foram encontradas elevadas correlações do consumo d'água com a radiação solar. Provavelmente, as condições climáticas ocorrentes nestas regiões permitiram que o manejo das estufas tenha dependido basicamente da incidência de radiação solar, tornando-se mais uniforme, permitindo que esta integrasse o efeito do manejo e das outras variáveis meteorológicas. Na região de Santa Maria existem outros fenômenos que freqüentemente interferem no manejo da estufa, como por exemplo, nevoeiros e ventos fortes do quadrante norte e sudeste. Dalsasso (1997) e Valandro (1999) encontraram bons coeficientes de determinação quando a radiação solar foi a 


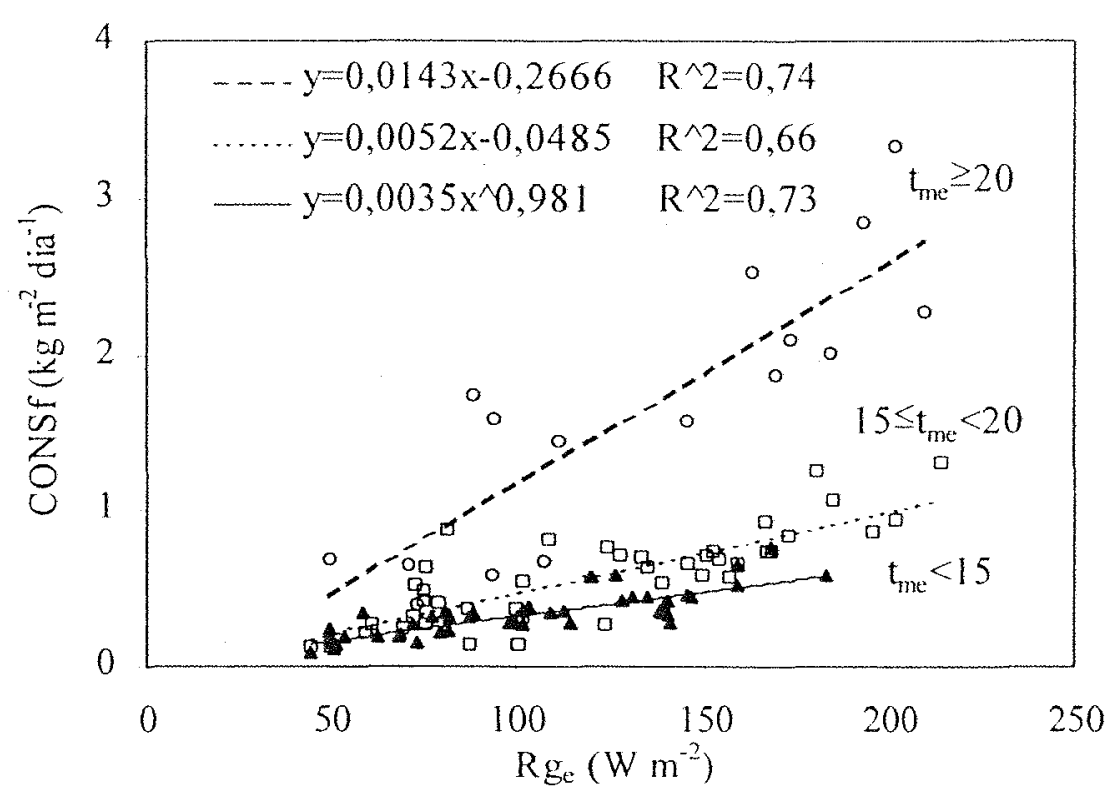

Figura 11: Correlação entre o consumo d'água diário por unidade de área foliar do tomateiro (CONSf) e a densidade de fluxo de radiação solar global no exterior da estufa $\left(R g_{e}\right)$ para as diferentes faixas de valores da temperatura média do ar no exterior da estufa $\left(t_{m c}\right)$. Período entre 18/03/99 e 04/07/99. Santa Maria, RS.

variável usada, cultivo de primavera-verão em Santa Maria, quando ocorrem com menor freqüência nevoeiros e entradas de frentes frias, sendo as estufas manejadas basicamente em função da incidência de radiação solar.

A radiação líquida no exterior da estufa $\left(R n_{e}\right)$, que quantifica a energia disponível para processos como a evapotranspiração, correlacionou-se melhor com CONSf (Figura 12), com um alto coeficiente de determinação, $\left(\mathrm{R}^{2}=0,82\right)$, sendo uma função potencial a de melhor ajuste. Logicamente, $R n_{e}$ teve um efeito positivo no consumo d'água pelas plantas, pois, quanto mais energia disponível, maior o potencial evaporativo do ar. Os valores mais afastados e acima da linha de tendência observados a partir de cerca de $60 \mathrm{~W} \mathrm{~m}^{-2}$ são referentes ao período entre 18 de março e 31 de abril, quando a temperatura média do ar no interior da estufa foi bastante elevada, $28,4^{\circ} \mathrm{C}$. 


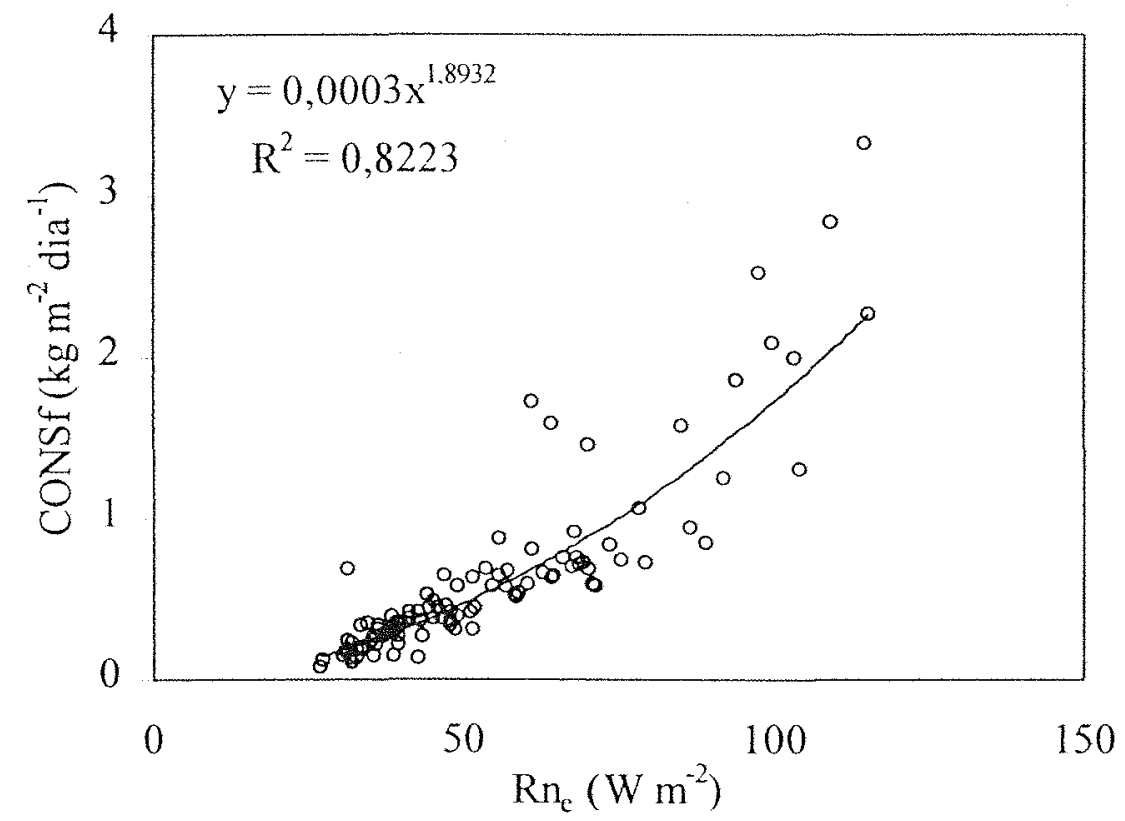

Figura 12: Correlação entre o consumo d'água diário por unidade de área foliar (CONSf) e a radiação líquida no exterior da estufa $\left(R n_{e}\right)$. Período entre 18/03/99 e 04/07/99, Santa Maria, RS.

A temperatura do ar no interior da estufa, também afetou positivamente o consumo d’água pelas plantas, como mostram as correlações de CONSf com a temperatura média diária $\left(t_{m i}\right)$ (Figura 13a), com a máxima diária $\left(t_{\text {imax }}\right)$ (Figura 13b) e com a média do período diurno $\left(t_{i d}\right)$, entre 6 e 18 horas, (Figura 13c). O melhor ajuste em toda a gama de variação dos dados foi obtido com funções exponenciais, as quais explicaram melhor a variação de CONSf, porém, obteve-se coeficientes de determinação mais elevados com funções lineares, como pode ser visto nas Figuras 13a, 13b, e 13c. O aumento de CONSf ocorreu em reposta do efeito da temperatura do ar sobre $D_{i}\left(\mathrm{R}^{2}=0,64\right.$ para $t_{\text {imax }}, \mathrm{R}^{2}=0,65$ para $t_{m i}$ e $\mathrm{R}^{2}=0,74$ para $t_{i d}$ ) e na resistência estomática que tende a diminuir com seu aumento. Valores da temperatura do ar elevados podem causar o aumento da $r_{s}$, porém, no período do ano em que foi conduzido o experimento, provavelmente não ocorreram valores suficientemente elevados para causar o fechamento estomático (ver ítem 4.2). 
A umidade relativa média diária do ar no interior da estufa $\left(U R_{m i}\right)$ teve um efeito potencial negativo sobre CONSf, com um bom coeficiente de determinação $\left(\mathrm{R}^{2}=0,78\right)$, conforme a Figura $14 \mathrm{a}$. A mesma tendência foi observada com a mínima diária no interior da estufa $\left(U R_{i m i n}\right)$, mas com maior dispersão dos dados $\left(\mathrm{R}^{2}=0,66\right)$, Figura 14b. Quando considerados os valores médios da umidade relativa do ar no período entre 6 e 18 horas $\left(U R_{i d}\right)$, Figura $14 \mathrm{c}$, foi observada a mesma tendência de $U R_{m i}$ e praticamente o mesmo ajuste dos dados $\left(\mathrm{R}^{2}=0,76\right)$. Os valores de $\mathrm{R}^{2}$ mais elevados quando correlacionados CONSf com $U R_{m i}$ e com $U R_{i d}$ deve-se, provavelmente, a estas integrarem os valores ocorridos quando a estufa foi mantida fechada durante o período diurno. A boa correlação de $U R_{m i}$ e $U R_{i d}$ con CONSf também pode ser explicada por seu efeito sobre $D_{i}$, $\left(\mathrm{R}^{2}=0,87\right.$ e $\mathrm{R}^{2}=0,85$, respectivamente) e, também, sua relação com $R g_{e}$ $\left(\mathrm{R}^{2}=0,73\right.$ para $U R_{m i}$ e $\mathrm{R}^{2}=0,75$ para a $\left.U R_{i d}\right)$.

A força motriz da transpiração das plantas é o gradiente de concentração de vapor entre os sítios de evaporação no interior da folha e o ar. Porém, a sua determinação é bastante dificultada em função da grande heterogeneidade da temperatura do dossel das plantas, além da dificuldade de medir-se a temperatura das folhas. No seu lugar pode-se adotar o déficit de saturação de vapor do ar como uma aproximação desta força.

A Figura 15 apresenta a correlação polinomial quadrática positiva entre $D_{i}$ e CONSf, com uma baixa dispersão dos dados $\left(\mathrm{R}^{2}=0,93\right)$. A forte relação entre CONSf . e $D_{i}$ não é surpreendente, pois, mesmo quando ocorreram valores elevados da densidade de fluxo de radiação solar incidente e temperatura do ar, mas com valores baixos de $D_{i}$, o fluxo transpiratório foi reduzido, enquanto que mesmo com valores não tão elevados de radiação solar incidente e com $D_{i}$ elevado, o fluxo transpiratório também o foi. Esta condição provavelmente ocorreu no dia 28 de junho, onde observa-se um pico no CONSf, mesmo que a densidade de fluxo de radiação solar incidente tenha sido baixa (Figura 9). É importante ressaltar que, devido a função de melhor ajuste dos dados ser uma polinomial quadrática, deve-se observar o intervalo de dados utilizados para gerar esta função $\left(0,06 \mathrm{kPa} \leq D_{i} \leq 1,38 \mathrm{kPa}\right.$ e $0,1 \mathrm{~kg} \mathrm{~m}^{-2} \mathrm{dia}^{-1} \leq$ CONSf $\left.\leq 3,3 \mathrm{~kg} \mathrm{~m}^{-2} \mathrm{dia}^{-1}\right)$. 


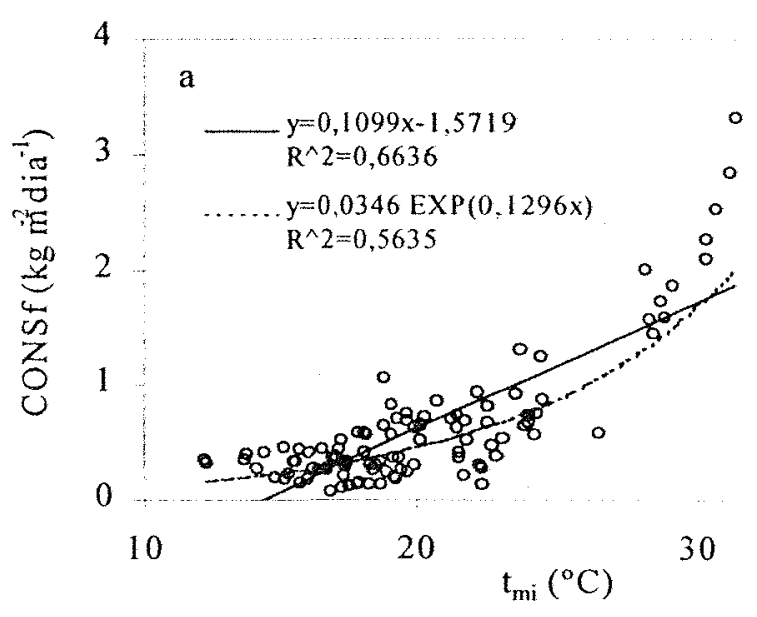

40
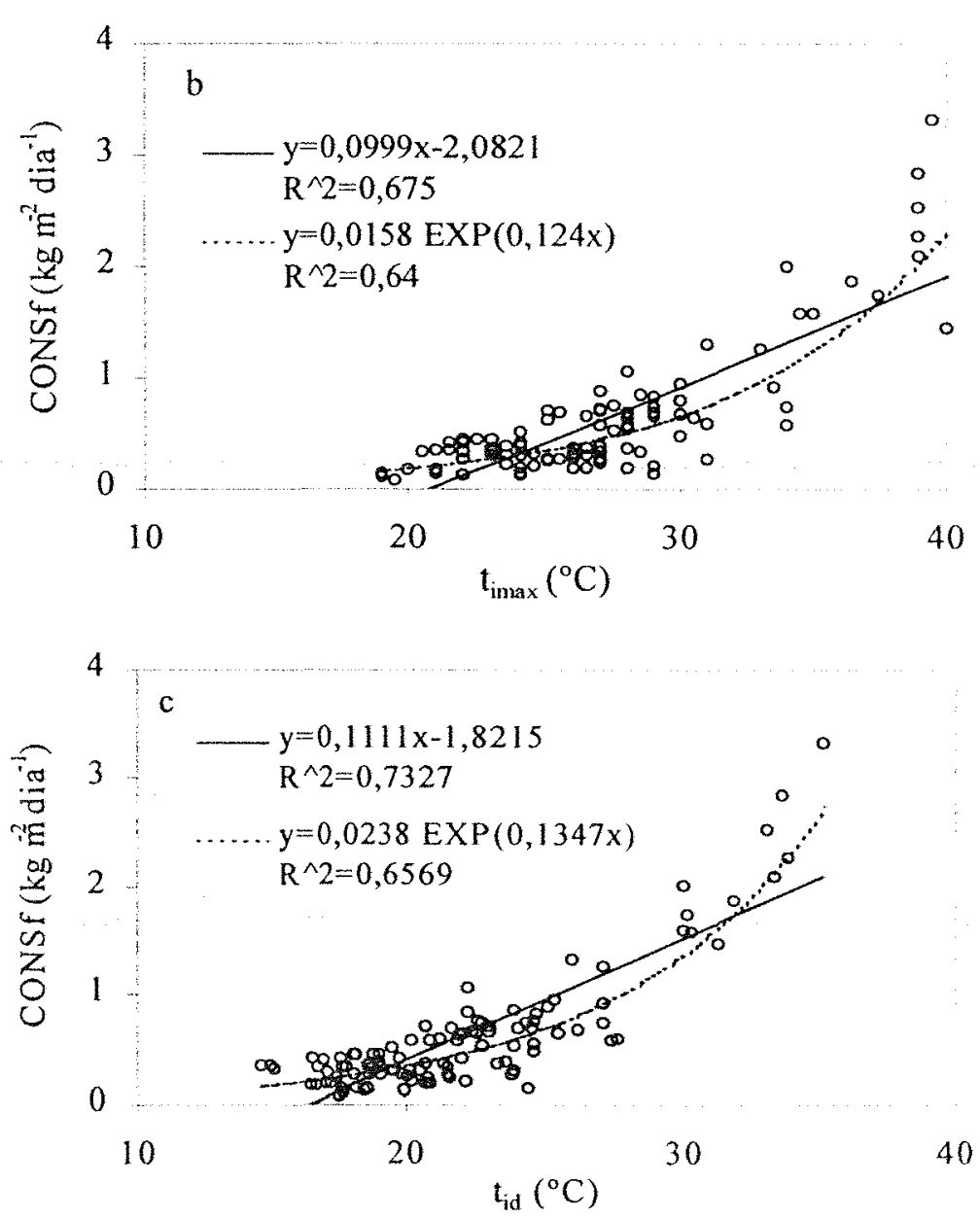

Figura 13: Correlação entre o consumo d'água diário por unidade de área foliar (CONSf) e a temperatura do ar no interior da estufa: a) média diária $\left(t_{m i}\right)$; b) máxima diária $\left(t_{\text {imax }}\right)$; c) média do período entre 6 e 18 horas $\left(t_{i d}\right)$. Período entre 18/03/99 e 04/07/99, Santa Maria, RS. 

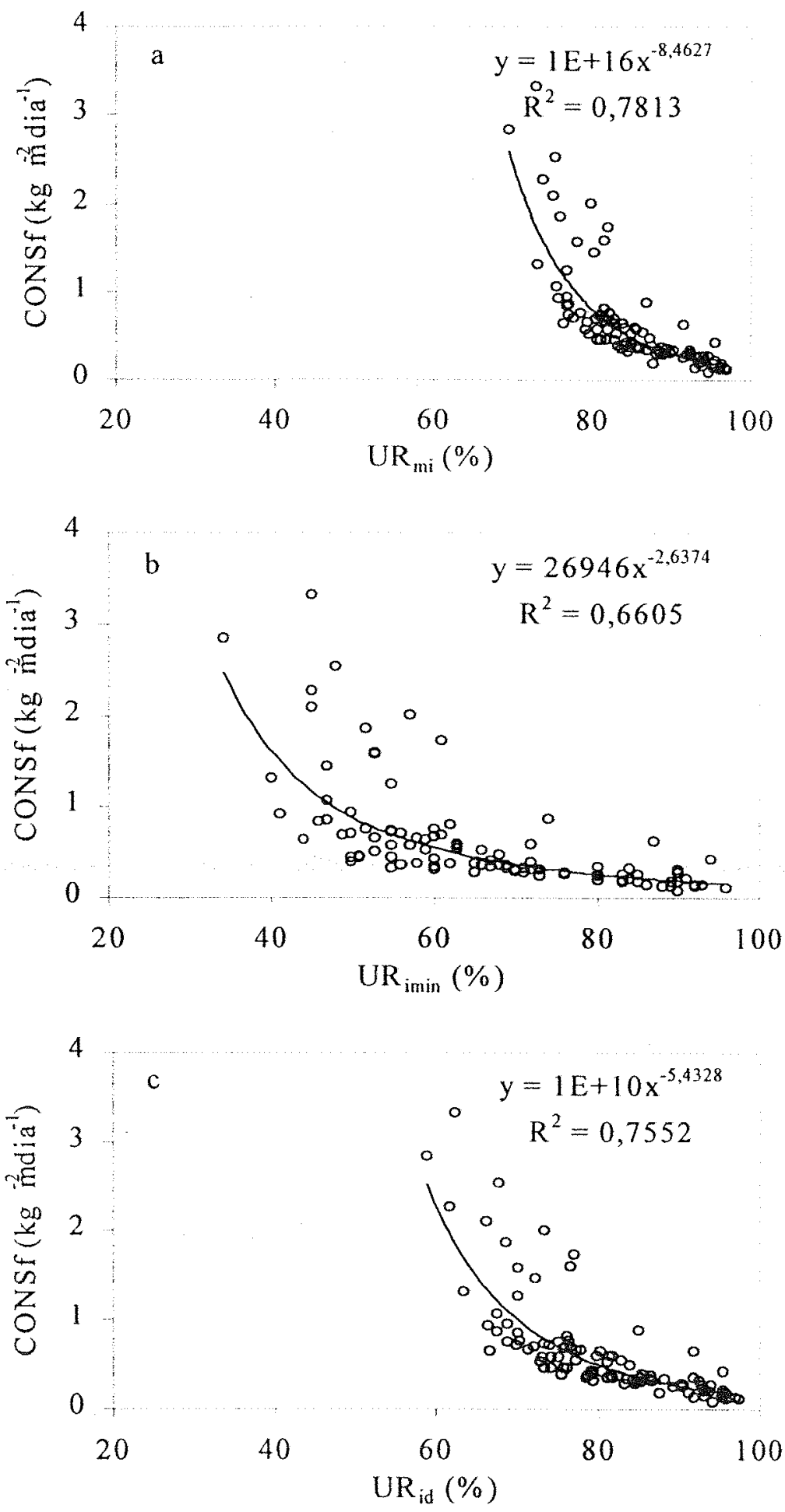

Figura 14: Correlação entre o consumo d'água diário por unidade de área foliar (CONSf) e a umidade relativa do ar diária no interior da estufa: a) média $\left(U R_{m i}\right)$; b) mínima $\left.\left(U R_{i m i n}\right) ; \mathrm{c}\right)$ média no período entre 6 e 18 horas $\left(U R_{i d}\right)$. Período entre 18/03/99 e 04/07/99, Santa Maria, RS. 
Estes resultados reforçam aqueles obtido por Valandro (1997), que concluiu ser mais eficiente a estimativa do consumo d'água pelas plantas no período de outono-inverno considerando-se a umidade relativa do ar.

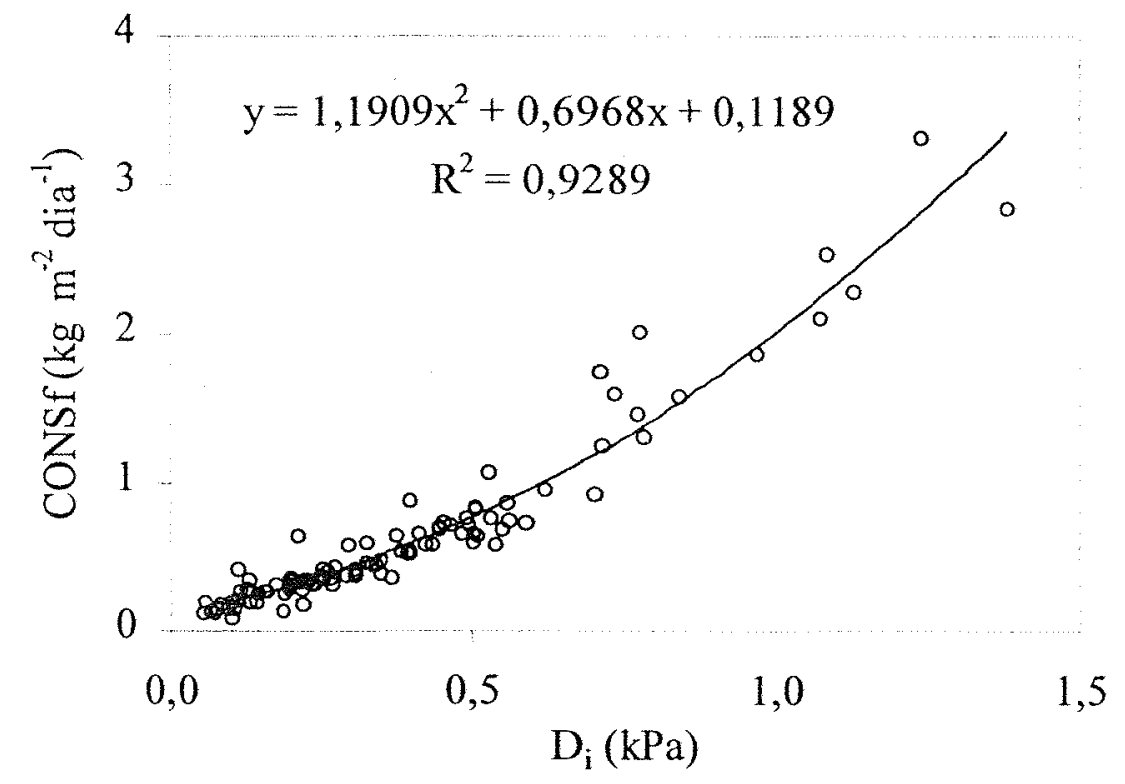

Figura 15: Correlação entre o consumo d'água diário por unidade de área foliar (CONSf) e o déficit de saturação do ar diário no interior da estufa $\left(D_{i}\right)$. Período entre 18/03/99 e 04/07/99, Santa Maria, RS.

A alta correlação entre CONSf e $D_{i}$ justifica os valores médios dos coeficientes de determinação obtidos com a $R g_{e}$. Na época em que foi conduzido o experimento, a freqüente ocorrência de dias frios e ensolarados, impediram a abertura da estufa para ventilação, ficando praticamente todo o vapor da transpiração das plantas e evaporação do solo retido no ambiente da estufa, ocasionando um déficit de saturação do ar reduzido. Desta maneira, o manejo da estufa não permitiu que a radiação solar integrasse o efeito do déficit de saturação do ar. Outra provável causa da boa correlação entre CONSf e $D_{i}$, foi o fechamento da estufa ao entrar uma frente fria, que normalmente trazia nebulosidade e chuva, mas mantinha o ar no interior da estufa com temperatura e 
déficit de saturação mais elevados do que no seu exterior, mantendo alto o potencial transpirante do ar, apesar da baixa irradiância solar.

O aumento até um determinado valor da irradiância solar e da temperatura do ar afeta positivamente a abertura estomática, diminuindo a resistência ao fluxo de vapor entre o interior da folha e o ar adjacente (no item 4.2, a Figura 3 mostra o . efeito da radiação solar na resistência estomática). No entanto, acima de um determinado valor de temperatura do ar ocorre uma produção de $\mathrm{CO}_{2}$ na respiração maior do que o assimilado no processo fotossintético, aumentando sua concentração na câmara estomática e na camada limite da folha, provocando o fechamento do estômato (Rutter, 1975). Portanto, mesmo existindo uma demanda hídrica no ar elevada, o que determina um certo potencial transpirante, a resistência da folha ao fluxo de vapor causada pelo fechamento estomático torna-se limitante para a transpiração. Por outro lado, um fluxo transpiratório acima de determinados valores altera o balanço hídrico da folha, podendo resultar em aumento da resistência estomática, limitando a própria transpiração.

Como o experimento foi conduzido no período de outono-inverno, quando os valores da temperatura e do déficit de saturação do ar não foram passíveis de provocar estresse térmico ou hídrico nas plantas (ver item 4.2), o consumo d'água pelo tomateiro foi afetado basicamente pela radiação solar, por seu efeito sobre a abertura estomática, e pelo próprio déficit de saturação do ar como força motriz da transpiração.

As temperaturas média $\left(t_{m e}\right)$ e máxima $\left(t_{e m a x}\right)$ diárias do ar no exterior da estufa também se correlacionaram positivamente com CONSf. $\mathrm{O} \mathrm{R}^{2}$ mais elevado obtido na correlação entre CONSf e $t_{m e}\left(\mathrm{R}^{2}=0,52\right)$ foi obtido com uma função linear, porém, uma função exponencial poderia explicar melhor a variação dos dados, mesmo com valor inferior do $\mathrm{R}^{2}\left(\mathrm{R}^{2}=0,45\right)$ (Figura 16a). Para $t_{e \max }$, o melhor ajuste foi encontrado com uma função exponencial $\left(\mathrm{R}^{2}=0,66\right)$ (Figura $16 \mathrm{~b}$ ). Nota-se que o coeficiente de determinação obtido com $t_{m i}$ (Figura 13) foi maior daquele com $t_{m e}$, pois o primeiro integra o periodo em que a estufa foi mantida fechada e as modificações microclimáticas causadas pela cobertura plástica. No entanto, aqueles obtidos com uso das máximas no interior e exterior da estufa foram praticamente iguais. Normalmente, a temperatura máxima do ar ocorreu quando a estufa estava com suas janelas e portas abertas para 
ventilação, e então, pela troca de ar ocorrida no interior e exterior da estufa, ocorreu uma flutuação diária semelhante entre ambos os ambientes.

A umidade relativa média diária do ar no exterior da estufa $\left(U R_{m e}\right)$ também correlacionou-se diferentemente com CONSf de acordo com as faixas de temperatura do ar no seu exterior. Para valores da $t_{m e} \geq 20^{\circ} \mathrm{C}$ não houve correlação entre a $U R_{m e}$ e o CONSf. Coeficientes de determinação ainda muito baixos foram obtidos nos dias em que $15^{\circ} \mathrm{C} \leq t_{m e}<20^{\circ} \mathrm{C}\left(\mathrm{R}^{2}=0,34\right)$, e quando $t_{m e}<15^{\circ} \mathrm{C}\left(\mathrm{R}^{2}=0,36\right)$, respectivamente, com funções de ajuste exponencial negativo, Figura 17a e $17 \mathrm{~b}$.

Ao correlacionar-se o CONSf com a umidade relativa do ar diária no exterior da estufa às 15 horas $\left(U R_{l S}\right)$, também foi observada alguma correlação somente para os dias em que as temperaturas externas da estufa foram menores do que $20^{\circ} \mathrm{C}$. . Quando $15^{\circ} \mathrm{C} \leq t_{m e}<20^{\circ} \mathrm{C}$, obteve-se $\mathrm{R}^{2}=0,48$ (Figura 18a), e quando $t_{m e}<15^{\circ} \mathrm{C}, \mathrm{R}^{2}=0,63$ (Figura 18b); da mesma forma que com a $U R_{m e}$, uma função exponencial negativa ajustou e explicou melhor os dados. Portanto, houve um efeito diferenciado de $U R_{15}$ sobre CONSf de acordo com os valores da $t_{m e}$. Os valores mais elevados de $\mathrm{R}^{2}$ quando considerada a $U R_{I 5}$ se deve ao fato da estufa normalmente estar aberta no horário de sua determinação, permitindo trocas do ar interno pelo externo $\left(\mathrm{R}^{2}=0,70\right.$ entre a $U R_{\text {imin }}$ e $U R_{\mathfrak{e}} 15 ; \mathrm{R}^{2}=0,39$ entre $U R_{m i}$ e $\left.U R_{m e}\right)$, tendo ambas praticamente o mesmo efeito sobre a transpiração.

Na correlação entre CONSf e o déficit de saturação do ar diário no exterior da estufa $\left(D_{e}\right)$, o coeficiente de determinação foi médio, $\mathrm{R}^{2}=0,57$ (Figura 19a). praticamente o mesmo daquele com o déficit de saturação do ar às 15 horas $\left(D_{e} / 5\right)$, $\mathrm{R}^{2}=0,59$ (Figura 19b), demonstrando que nenhum deles teve grande influência naquele do interior. Porém, ao separar-se os dias por faixas de $t_{m e}$, quando esta menor de $15^{\circ} \mathrm{C}$, obteve-se $\mathrm{R}^{2}$ mais elevado quando usou-se $D_{e} 15\left(\mathrm{R}^{2}=0,74\right)$. 

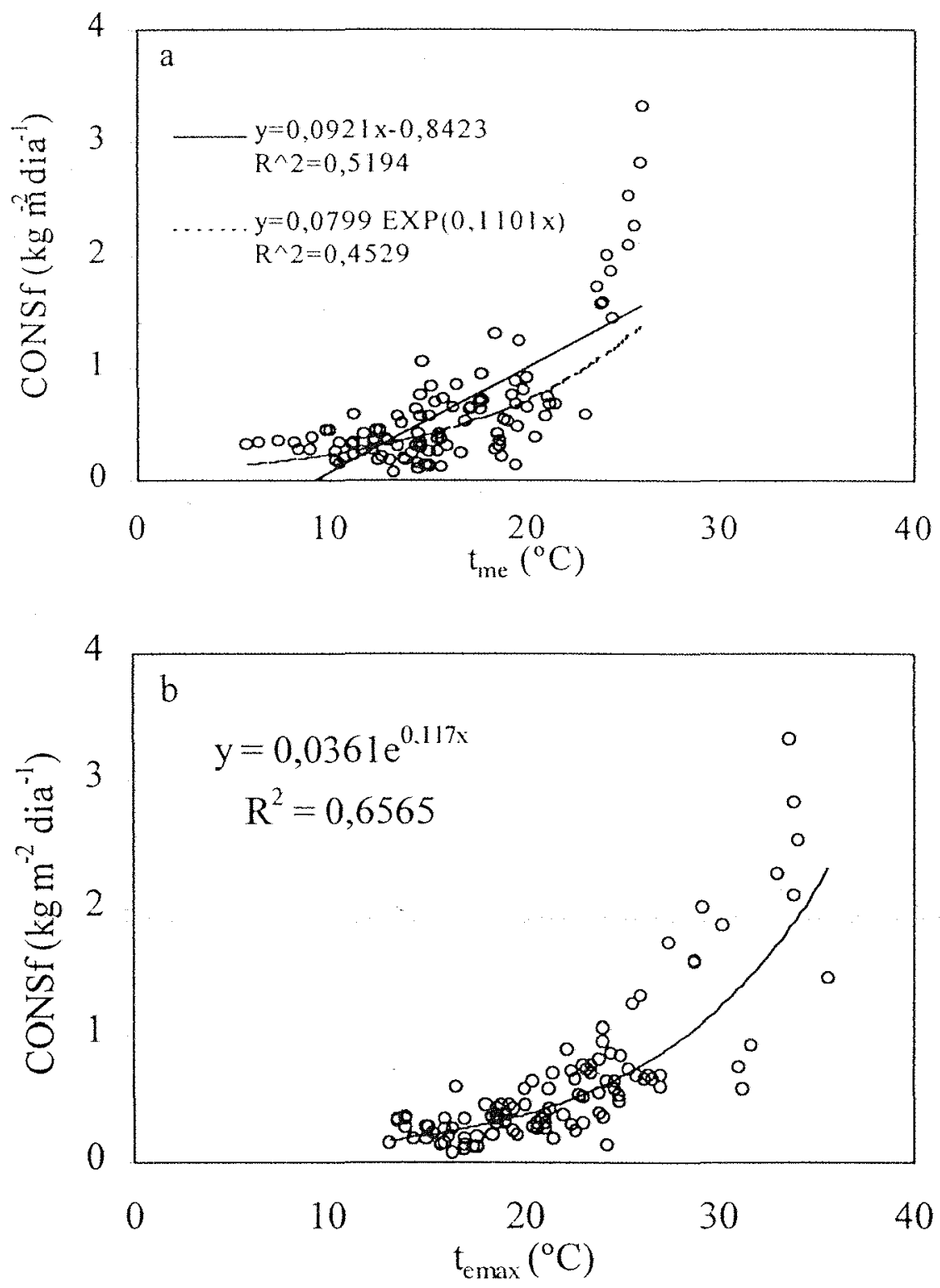

Figura 16: Correlação do consumo d'água diário por unidade área foliar (CONSf) com a temperatura diária do ar no exterior da estufa: a) média $\left(t_{m e}\right)$; b) máxima $\left(t_{\text {emax }}\right)$. Período entre 18/03/99 e 04/07/99, Santa Maria, RS. 

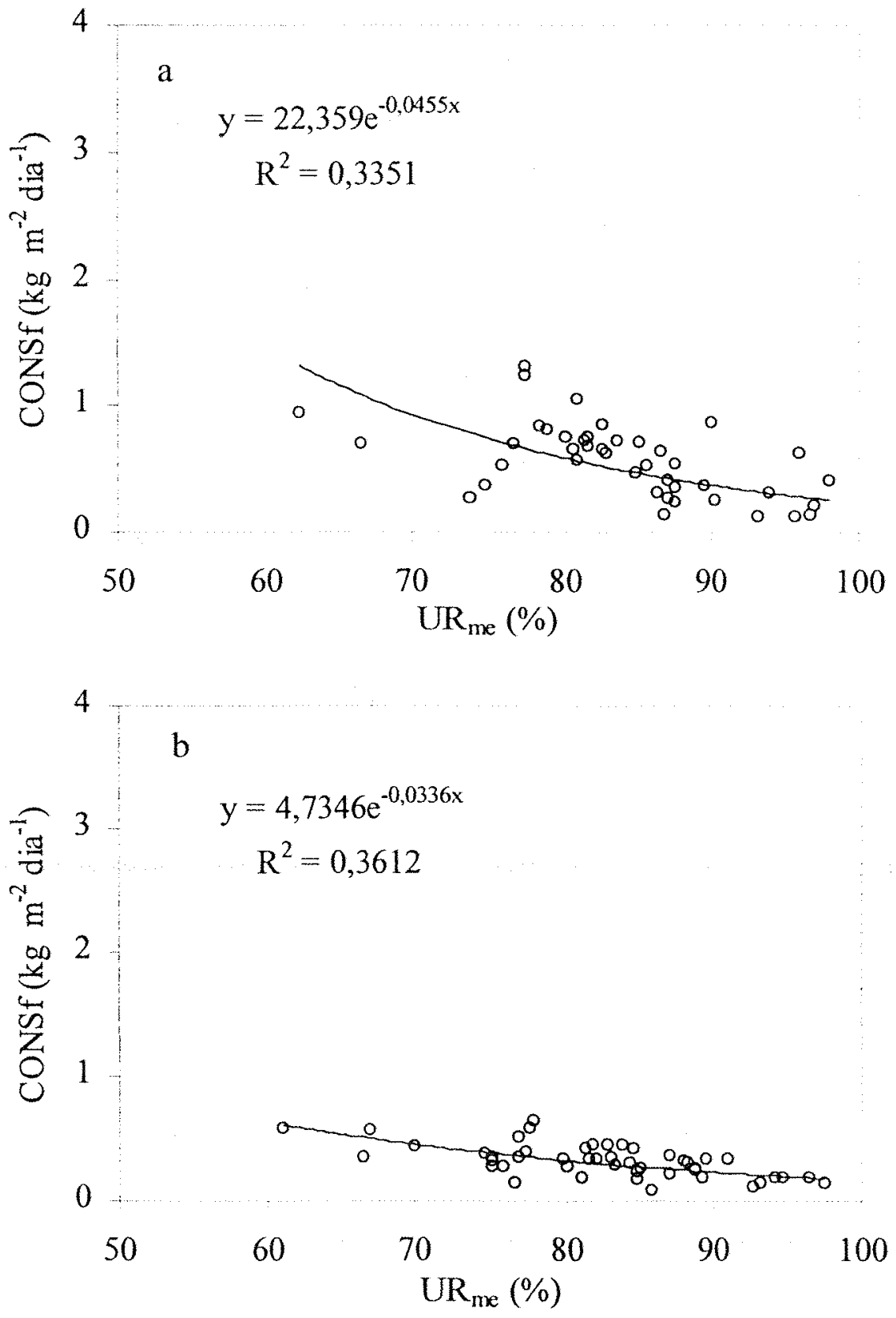

Figura 17: Correlação do consumo d'água diário por unidade área foliar (CONSf) com a umidade relativa média diária do ar no exterior da estufa $\left(U R_{m e}\right)$ conforme faixas dos valores da temperatura média diária do ar no exterior da meśma $\left(t_{m e}\right)$ : a) $15^{\circ} \mathrm{C} \leq t_{m e}<20^{\circ} \mathrm{C}$; b) $t_{m e}<15^{\circ} \mathrm{C}$. Período entre $18 / 03 / 99$ e $04 / 07 / 99$, Santa Maria, RS. 

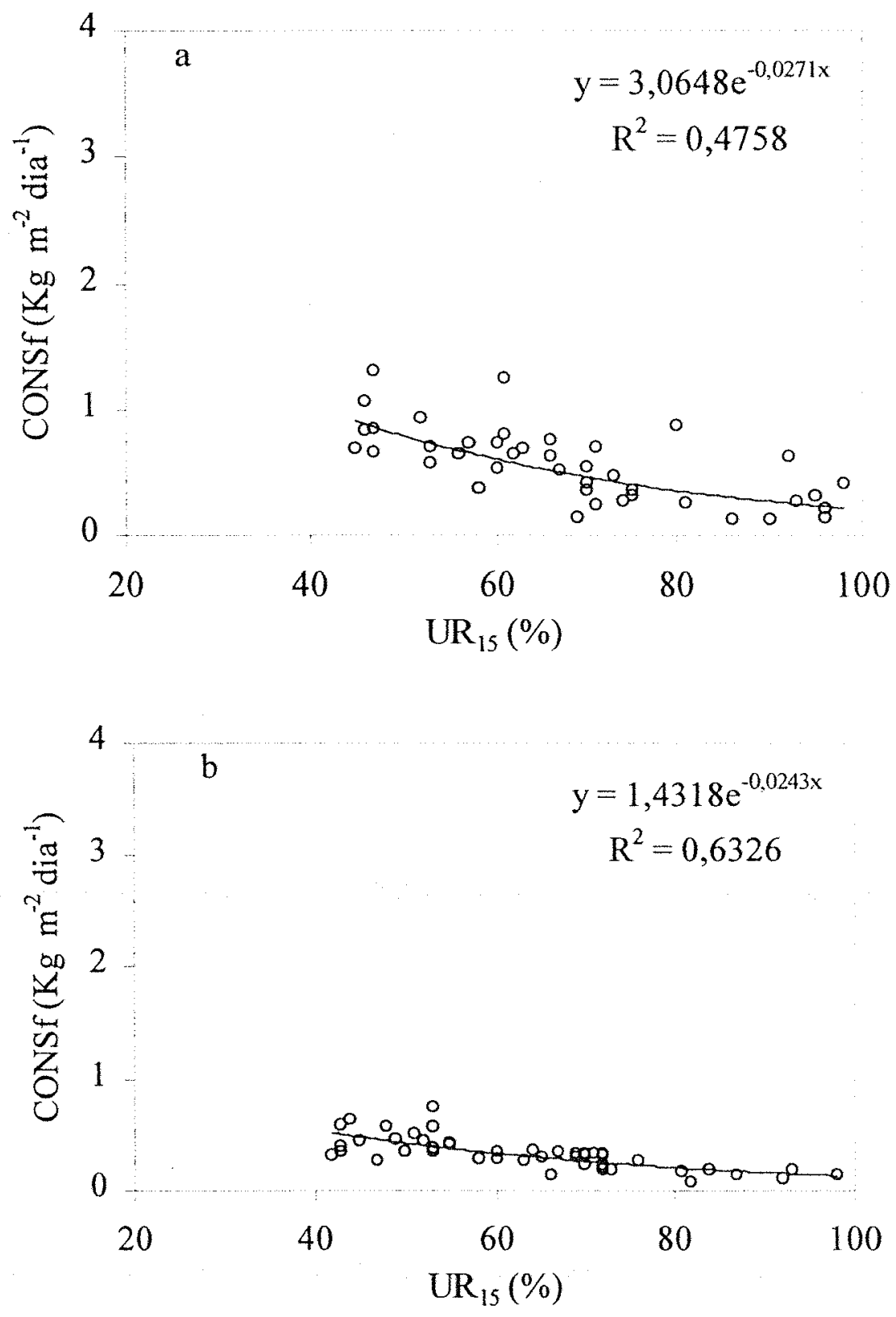

Figura 18: Correlação do consumo d'água diário por unidade área foliar (CONSf) com a umidade relativa do ar no exterior da estufa medida às 15horas $\left(U R_{I S}\right)$ conforme faixas da temperatura média diária do ar no exterior da mesma $\left(t_{m e}\right)$ : a) $15^{\circ} \mathrm{C} \leq t_{m e}<20^{\circ} \mathrm{C}$; b) $t_{m e}<15^{\circ} \mathrm{C}$. Período entre $18 / 03 / 99$ e $04 / 07 / 99$, Santa Maria, RS. 

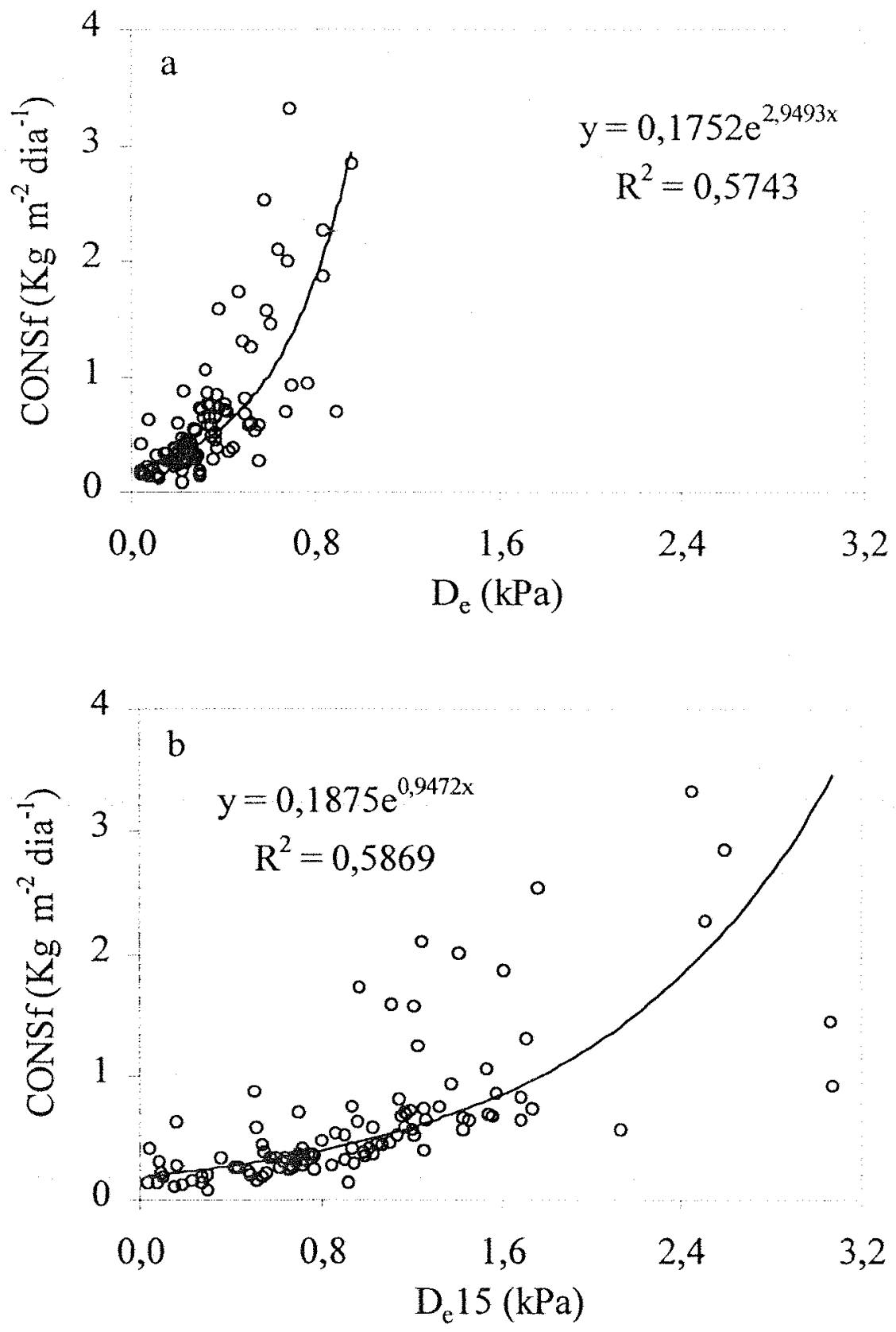

Figura 19: Correlação do consumo d'água diário por unidade de área foliar (CONSf) com: a) o déficit de saturação do ar diário no exterior da estufa $\left(D_{e}\right)$; b) com o déficit de saturação do ar calculado para as 15 horas $\left(D_{e} 15\right)$. Período entre 18/03/99 e 04/07/99, Santa Maria, RS. 
Pode-se notar que a dispersão dos dados quando correlacionado CONSf com as variáveis meteorológicas no exterior da estufa foi maior do que quando correlacionado com aquelas do interior. Isto significa que as plantas responderam principalmente às condições micrometeorológicas da estufa. Este efeito pode ser observado nas correlações com as temperaturas máximas e a umidade relativa do ar medida às 15 horas no exterior da estufa, do que quando esta normalmente estava aberta para ventilar, permitindo que as condições internas fossem fortemente influenciadas pelas externas, obtendo-se coeficientes de determinação mais elevados quando utilizadas as médias. Resultados semelhantes foram obtidos por Scatolini (1996), que também encontrou maior correlação do consumo d'água do crisântemo com as variáveis meteorológicas medidas no interior da estufa.

O maior ajuste dos dados obtido entre CONSf e as variáveis meteorológicas medidas no interior da estufa, ocorreu em função destas integrarem o efeito da cobertura plástica e o manejo das janelas laterais e portas frontais. Entretanto, deve-se ressaltar que as condições meteorológicas ocorridas no interior da estufa dependeram daquelas do exterior.

Outra observação a ser feita, é que CONSf correlacionou-se melhor com os valores médios das variáveis no interior da estufa do que com os valores extremos (como $U R_{\text {imin }}$ ), pois os valores médios integraram o efeito do manejo da estufa ao longo . do dia. Por exemplo, se a estufa foi mantida fechada durante parte do dia e aberta no início da tarde após dissipação de nevoeiro, ocorreu, então, um valor extremo, o qual pode ser encontrado também para dias totalmente ensolarados, nos quais a estufa foi aberta no início da manhã. 


\subsection{Correlações múltiplas do consumo d'água diário por unidade de área foliar com as variáveis meteorológicas}

Devido não se ter medido a densidade de fluxo de radiação solar global no interior da estufa, nas correlações múltiplas com as variáveis meteorológicas no. interior da estufa (temperatura, umidade relativa e déficit de saturação do ar), utilizou-se $R g_{e}$, cuja variação diária pode ser considerada proporcional aquela que ocorre no interior.

A Tabela 2 apresenta as equações de regressão de CONSf com as variáveis externas à estufa. Observa-se que, das variáveis meteorológicas utilizadas no trabalho, a temperatura do ar apareceu em quase todos os modelos selecionados por ajustarem melhor os dados, haja visto a flutuação da $t_{m e}$ ter sido praticamente a mesma de $t_{m i}$ (Figura 6b).

Conforme visto nas correlações realizadas individualmente entre CONSf e as variáveis meteorológicas, $R n_{\varepsilon}$ ajustou melhor os dados do que $R g_{e}$.

Os melhores $\mathrm{R}^{2}$ foram obtidos com $R n_{e}, t_{m e}$ e $D_{e}\left(\mathrm{R}^{2}=0,81\right)$; com $R n_{e}$ e $t_{m e}{ }^{2}$. $\left(\mathrm{R}^{2}=0,80\right)$ ou $R g_{e}$ e $t_{e \max }\left(\mathrm{R}^{2}=0,79\right)$. É importante ressaltar que neste trabalho, $R g_{e}$ e $R n_{e}$ foram estimadas, o que reduz sensivelmente a precisão dos seus valores, devendo-se observar com ressalva estes modelos.

A Tabela 3 apresenta os modelos de regressão de CONSf com as variáveis meteorológicas obtidas no interior da estufa.

$\mathrm{Na}$ comparação entre o efeito das variáveis meteorológicas internas e externas à estufa, novamente as primeiras apresentaram coeficientes de determinação mais elevados, sendo $D_{i}$ a variável meteorológica mais importante, como já discutido anteriormente. Considerando-se somente $D_{i}$, foi obtido $\mathrm{R}^{2}=0,90$ e acrescentando-se o seu quadrado, $\mathrm{R}^{2}=0,94$. Neste caso, a utilização de um termômetro de bulbo seco e outro de bulbo úmido seriam suficientes para estimar CONSf, necessitando-se da $A F$ para obter o CONS $($ CONS $=$ CONSf.AF $)$. 
Substituindo-se $D_{i}$ por $R n_{e}$, mais $D_{i}^{2}$, novamente obteve-se $\mathrm{R}^{2}=0,94$, porém, neste caso, o cálculo da $R n_{e}$ é mais complexa, dificultando sua aplicabilidade a nível de produtor.

Para fins práticos, é interessante conhecer-se o efeito das variáveis meteorológicas do exterior da estufa no consumo d'água das plantas cultivadas neste tipo de ambiente, para que, a partir de uma estação meteorológica, se possa cobrir uma grande quantidade de produtores, com informações de estimativas do consumo d'água de determinada cultura. Porém, com estas variáveis, se estará errando mais do que se utilizados os valores locais das variáveis meteorológicas internas da estufa.

Os modelos apresentados nas Tabelas 2 e 3 são válidos para determinados intervalos de dados das variáveis utilizadas na estimativa dos seus coeficientes, os quais estão apresentados na Tabela 4.

Tabela 2: Modelos obtidos por regressão múltipla, do consumo d'água diário por unidade de área foliar do tomateiro (CONSf) cultivado no interior de uma estufa plástica com as variáveis meteorológicas do exterior da estufa e seus respectivos coeficientes de determinação $\left(\mathrm{R}^{2}\right)$, considerando-se 105 observações.

\begin{tabular}{ll}
\hline Modelos de regressão múltipla & $\mathbf{R}^{2}$ \\
\hline CONSf $=-1,3935+0,0040 \cdot R g_{e}+0,0718 \cdot t_{\text {max }}$ & 0,68 \\
CONSf $=-0,7584+0,0539 \cdot t_{m e}+1,6295 \cdot D_{e}$ & 0,70 \\
CONSf $=-1,3309+0,0063 \cdot R g_{e}+0,0776 \cdot t_{\text {me }}$ & 0,73 \\
CONSf $=0,7999+0,0030 \cdot t_{m e}{ }^{2}-0,144 \cdot 10^{-3} \cdot U R_{m e}{ }^{2}$ & 0,73 \\
CONSf $=-0,7230+0,0057 \cdot R g_{e}+0,0026 \cdot t_{m e}^{2}$ & 0,80 \\
CONSf $=-0,7018+0,0248 \cdot R n_{e}$ & 0,78 \\
CONSf $=-0,9059+0,0208 \cdot R n_{e}+0,0265 \cdot t_{\text {me }}$ & 0,80 \\
CONSf $=-0,8620+0,0171 \cdot R n_{e}+0,0241 \cdot t_{m e}+0,5842 \cdot D_{e}$ & 0,81 \\
CONSf $=-0,9808+0,0198 \cdot R n_{e}+0,0251 \cdot t_{\text {emax }}$ & 0,79
\end{tabular}

$R g_{c}$ é a densidade de fluxo de radiação solar global incidente no exterior da estufa $\left(\mathrm{W} \mathrm{m}^{-2}\right) ; R n_{e}$ é a radiação líquida no exterior da estufa $\left(\mathrm{W} \mathrm{m}^{-2}\right) ; t_{m}, D_{e}, U R_{m e}$, são, respectivamente, a temperatura média $\left({ }^{\circ} \mathrm{C}\right)$, o déficit de saturação $(\mathrm{k} P a)$ e a umidade relativa média $(\%)$, diários do ar no exterior da estufa; $\boldsymbol{t}_{\text {emmax }}$ é a temperatura máxima diária do ar no exterior da estufa $\left({ }^{\circ} \mathrm{C}\right)$. 
Tabela 3: Modelos obtidos por regressão múltipla, do consumo d'água diário por unidade de área foliar do tomateiro (CONSf) cultivado no interior de uma estufa plástica com as variáveis meteorológicas do interior da estufa e seus respectivos coeficientes de determinação $\left(\mathrm{R}^{2}\right)$, considerando-se 105 observações.

\begin{tabular}{|c|c|}
\hline Modelos de regressão múltipla & $\mathrm{R}^{2}$ \\
\hline$C O N S f=-0,1538+2,0824 . D_{i}$ & 0,90 \\
\hline CONSf $=0,0864+0,8133 \cdot D_{i}+1,1109 \cdot D_{i}^{2}$ & 0,94 \\
\hline$C O N S f=2,2767+0,0807 \cdot t_{m i}-0,0382 . U R_{m i}$ & 0,80 \\
\hline$C O N S f=0,1152+0,1713 \cdot D_{\text {imax }}+0,1028 \cdot D_{\text {imax }}{ }^{2}$ & 0,85 \\
\hline$C O N S f=-1,8256+0,0053 \cdot R g_{e}+0,0921 . t_{m i}$ & 0,80 \\
\hline$C O N S f=2,7135+0,0026 \cdot t_{m i}^{2}-0,0343 \cdot U R_{m i}$ & 0,85 \\
\hline CONSf $=0,2436+0,0031 . R g_{e}+0,0848 . t_{m i}-0,0194 . U R_{m i}$ & 0,81 \\
\hline CONSf $=-0,3791+0,0150 \cdot t_{m i}+1,8828 \cdot D_{i}$ & 0,90 \\
\hline$C O N S f=-0,4689+0,119 \cdot R n_{e}+0,3351 \cdot D_{\text {imax }}$ & 0,84 \\
\hline CONSf $=-0,2271+0,0113 \cdot R n_{e}+0,0914 \cdot D_{\text {imax }}{ }^{2}$ & 0,89 \\
\hline CONSf $=-1,4374+0,0173 \cdot R n_{e}+0,0420 . t_{\max }$ & 0,82 \\
\hline CONSf $=-1,2273+0,0175 \cdot R n_{e}+0,0458 . t_{m i}$ & 0,82 \\
\hline$C O N S f=-0,0149+0,0065 \cdot R n_{e}+1,3945 \cdot D_{i}^{2}$ & 0,94 \\
\hline CONSf $=0,2554+1,7500 \cdot D_{i}^{2}$ & 0,92 \\
\hline
\end{tabular}

$R g_{c}$ é a densidade de fluxo de radiação solar global incidente no exterior da estufa $\left(\mathrm{W} \mathrm{m}^{-2}\right) ; R n_{e}$ é a radiação liquida no exterior da estufa $\left(\mathrm{W} \mathrm{m}^{-2}\right) ; U R_{m i}, t_{m i}$ e $D_{i}$ são, respectivamente, a umidade relativa média $(\%)$, a temperatura média $\left({ }^{\circ} \mathrm{C}\right)$ e o déficit de saturação $(\mathrm{kPa})$, diários do ar no interior da estufa e $D_{\text {imar }}$ é o déficit de saturação do ar máximo diário $(\mathrm{kPa}), t_{\text {imer }}$ é a temperatura máxima do ar no interior da estufa $\left({ }^{\circ} \mathrm{C}\right)$.

É importante salientar a necessidade de ser testada a validade destes modelos com dados independentes. Estes modelos são referentes às condições ambientais da região de Santa Maria, devendo-se testá-los em caso da utilização em outros locais. 
Tabela 4: Intervalo de valores utilizados de cada variável meteorológica dos modelos.

\begin{tabular}{lcclllll}
\hline $\begin{array}{l}\text { Var. } \\
\text { Meteo. }\end{array}$ & V. Mín. & V. Max. & Unidade & $\begin{array}{l}\text { Var. } \\
\text { Meteo. }\end{array}$ & V. Min. & V. Max. Unidade \\
\hline $\boldsymbol{R g}_{\boldsymbol{e}}$ & 44,3 & 214,2 & $\mathrm{~W} \mathrm{~m}^{-2}$ & $U R_{m e}$ & 61 & 98 & $\%$ \\
$\boldsymbol{R}_{\boldsymbol{e}}$ & 26,9 & 115,0 & $\mathrm{~W} \mathrm{~m}^{-2}$ & $\boldsymbol{t}_{\boldsymbol{m} e}$ & 5,7 & 26 & ${ }^{\circ} \mathrm{C}$ \\
$\boldsymbol{U} \boldsymbol{R}_{\boldsymbol{m} i}$ & 69,5 & 97,1 & $\%$ & $\boldsymbol{D}_{\boldsymbol{e}}$ & 0,04 & 0,96 & $\mathrm{kPa}$ \\
$\boldsymbol{t}_{\boldsymbol{m} \boldsymbol{i}}$ & 12,1 & 31,4 & ${ }^{\circ} \mathrm{C}$ & $\boldsymbol{t}_{\boldsymbol{e m a x}}$ & 13,2 & 35,6 & ${ }^{\circ} \mathrm{C}$ \\
$\boldsymbol{D}_{\boldsymbol{i}}$ & 0,06 & 1,38 & $\mathrm{kPa}$ & $\boldsymbol{A F}$ & 0,16 & 1,37 & $\mathrm{~m}^{2}$ \\
$\boldsymbol{D}_{\boldsymbol{i m a x}}$ & 0,09 & 4,61 & $\mathrm{kPa}$ & $\boldsymbol{C O N S f}$ & 0,08 & 3,32 & $\mathrm{kgm}^{-2} \mathrm{dia}^{-1}$ \\
\hline
\end{tabular}

\subsection{Razão entre consumo d'água e a evapotranspiração de referência $(T R / E T o)$}

A Figura 20 apresenta as flutuações diária e semanal e uma linha de ajuste suavizada da razão entre o consumo d'água do tomateiro e a evapotranspiração de referência $(T R / E T o)$. A grande flutuação diária ocorreu em resposta às diferentes condições meteorológicas do interior e do exterior da estufa, que ocorreram, principalmente, em função do manejo da mesma. Os picos observados entre os dias $4 \mathrm{e}$ 11 de junho, este último igual a 7,86, se devem à forma de calcular a radiação líquida, a qual, nestes dias, apresentou valores muito baixos, resultando em ETo muito baixa. Como os valores apresentados são referentes à razão entre a transpiração no interior da estufa, que foi afetada pelas condições internas, e a evapotranspiração de referência que foi baixa nestes dias, sendo que ao dividir-se um valor por outro bastante inferior, resulta em outro elevado.

As médias semanais tenderam a aumentar até a primeira dezena de junho, enquanto que a linha de ajuste aumentou até a segunda semana de maio. Observando-se a curva de ajuste, que ameniza a grande flutuação diária, o crescimento da relação pode ser explicado pelo crescimento das plantas, e um posterior declínio, fruto da estabilizaçã̃o da área foliar e, até mesmo, sua diminuição, causada pelas senescência das 
folhas, doenças foliares e paralisação do crescimento das plantas. Porém, a principal causa do declínio da TR/ETo pode ter sido o manejo da estufa, que, mantida mais tempo fechada para armazenar calor no decorrer do experimento, reteve o vapor d'água em seu microambiente, reduzindo a demanda hídrica do ar com maior intensidade do que no exterior. No período de 18 de março até 19 de maio, o déficit de saturação médio do ar no interior da estufa foi $0.11 \mathrm{kPa}$ maior que aquele do exterior, enquanto que do dia 25 de maio até 4 de julho, o déficit de saturação do ar no interior da estufa foi $0,04 \mathrm{kPa}$ menor que aquele no exterior, ou seja, o potencial evaporante do ar no interior da estufa foi menor do que no exterior neste último período.

Em 18 de março, quando as plantas estavam com 19 dias após o transplante $(D A T)$ o valor de TR/ETo foi 0,3 , aumentando, a seguir, até atingir um máximo em torno de 1,95, quando considerado a curva de ajuste, com cerca de $87 \mathrm{DAT}$. No final do período experimental, aos 127 DAT, obteve-se o valor de aproximadamente 1,3. As médias semanais também apresentaram uma grande flutuação, sendo menos preciso observar-se estes valores.

Para a mesma época de cultivo, trabalhando com uma cultivar de tomateiro de hábito de crescimento indeterminado cultivado diretamente no solo, Dalsasso (1997) também encontrou um crescimento da razão entre a evapotranspiração real do tomateiro cultivado em estufa e a de referência, denominado pelo autor de coeficiente de cultura $(K c)$, até atingir um máximo para uma posterior diminuição. Os valores iniciais por ele obtidos foram um pouco mais elevados que no presente trabalho, 0,59 aos $31 \mathrm{DAT}$, considerando a distribuição da água de irrigação em $100 \%$ da área da superfície de solo disponível para cada planta ( 1100$)$, e 0,78 considerando a distribuição da água em $80 \%$ da superfície de solo disponível para cada planta (180), sendo estes critérios adotados porque a irrigação realizada por gotejamento normalmente não tem uma distribuição uniforme solo. Os valores máximos obtidos pelo autor foram inferiores daqueles obtidos neste trabalho, sendo de 1,44 e 1,75, respectivamente, para 1100 e 180 aos $75 D A T$. Com $125 D A T$, ele obteve valores de $K_{c}$ de 0,81 para $I 100$ e 0,95 para $I 80$. 


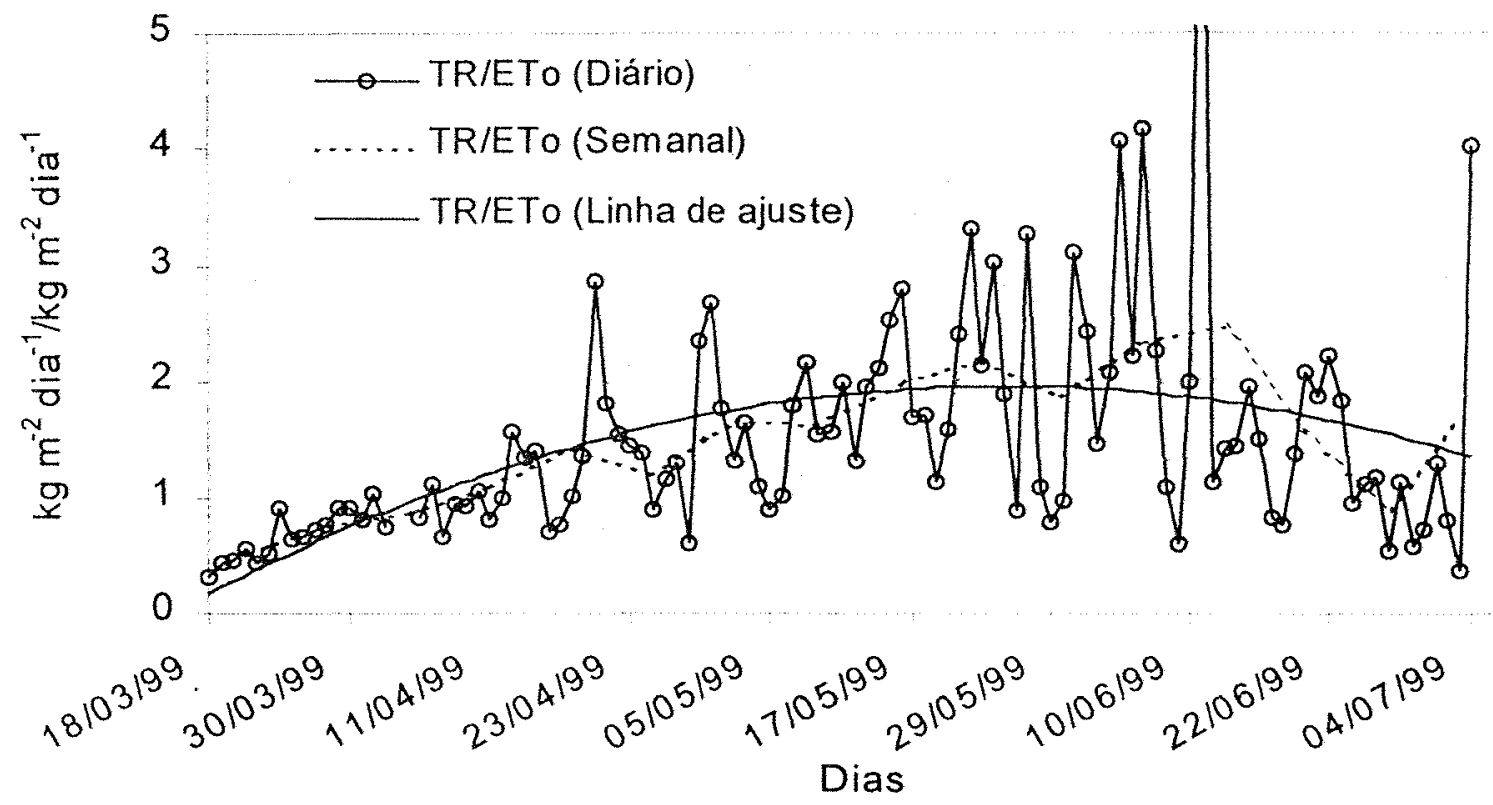

Figura 20: Flutuação diária e das médias semanais da razão entre a transpiração do tomateiro e a evapotranspiração de referência (TR/ETo) e sua linha de ajuste. Período entre 18/03/99 e 04/07/99, Santa Maria, RS. 


\section{CONCLUSÕES}

- Foi possivel a análise do efeito isolado das variáveis meteorológicas sobre o consumo hídrico do tomateiro em estufa quando o consumo foi expresso por unidade de área foliar.

- Foram encontradas boas correlações entre o consumo hídrico por unidade de área foliar com a irradiância solar, e melhor ainda com a radiação líquida no exterior da estufa, mas no período de outono-inverno, o melhor ajuste do consumo hídrico foi obtido com a variável déficit de saturação do ar no interior da mesma.

- Os valores médios diários e diurnos das variáveis meteorológicas no interior da estufa explicaram melhor a variação da transpiração das plantas do que os valores extremos ou de determinados horários do dia.

- Na comparação entre o efeito das variáveis meteorológicas do interior e exterior da estufa, as primeiras correlacionaram-se melhor com os dados de consumo d'água por unidade de área foliar.

- A razão consumo d'água/evapotranspiração de referência, no cultivo de outonoinverno, aumentou inicialmente, em função principalmente do aumento da área foliar, para depois decrescer, como resposta da redução da demanda hídrica do ar atmosférico. 


\section{REFERÊNCIAS BIBLIOGRÁFICAS}

ALPI, A.; TOGNONI, F. Cultura em estufas. $2^{\text {a }}$ ed., Lisboa, Editorial presença Ltda., 1987.201p.

ANDERLINI, R. A cultura do tomate. Portugal, Ed. Litexa, 1982. 164p.

ANDRIOLO, J. L. \& POERSCHKE, P. R. C. Cultivo do tomateiro em substratos. Santa Maria: UFSM - Centro de Ciências Rurais, 1997. 12p. (Informe Técnico, 2).

BAILEY, B. J. Microclimate, physical processes and greenhouse tecnology. Acta Horticulturae, v.174, p.35-42, 1985.

BAILLE, A. Irrigation management strategy of greenhouse crops in Mediterranean coutries. International Society for Horticultural Science, Wageningen, p.105$122,1994$.

BAILLE, M.; BAILLE, A.; LAURY, J. C.. A simplified modet for predicting evapotranspiration ratef nine ornamental species vs. climate factors and leaf carea. Scientia Horticulturae, v.59, p.217-232, 1994.

BAILLE, M.; DELMON, D.; BAILLE, A.; BOMTEMPS, J.; JACQUEMONT, R.. Microclimat et transpiration d'une culture de rosiers hors sol sous serre. Revue Horticole, v.320, octobre 1991.

BAILle, M.; LAURY, J.C.; BAILlE, A.. Some comparative results on evapotranspiration of greenhouse ornamental crops, using lysimeter, greehouse $\mathrm{H}_{2} \mathrm{O}$ balance and LVDT sensors. Acta Horticulturae, v.304, p.199-208, 1992.

BOULARD, T.; BAILLE, A.; MERMIER, M.; VILLETTE, F. Mesures et modélisation de la résistance stomatique foliaire et de la transpiration d'un covert de tomates de serre. Agronomie, v.11, 259-274, 1991.

BOULARD, T.; JEMAA, R.. Greenhouse tomato crop transpiration model application to irrigation control. Acta Horticulturae, v.335, p.381-387, 1993.

BOULARD, T.; JEMAA, R.; BAILLE, A. Validation of a greenhouse tomato crop transpiration model in Mediterranean conditions. Acta Horticulturae, n.2, v.449, p.551-559, 1997. 
BURIOL, G. A.; LUFT, S. V. L.; HELDWEIN, A. B.; STRECK, N.A.; SCHNEIDER, F. M. Efeito da ventilação sobre a temperatura e umidade do ar em túneis baixos de polietileno transparente e o crescimento da alface. Revista Brasileira de Agrometeorologia, Santa Maria, v.5, n.1, p.17-24, 1997.

BURIOL, G. A.; SCHENEIDER, F. M.; ESTEFANEL, V.; ANDRIOLO, J. L.; MEDEIROS, S. L. P. Modificação na temperatura mínima do ar causada por estufas de polietileno transparente de baixa densidade. Revista Brasileira de Agrometeorologia. Santa Maria. v.1, n.1, p.43-49, 1993.

BURIOL, G. A.; SCHNEIDER, F. M.; HELDWEIN, A. B.; STRECK, N. A.; ESTEFANEL, V.; RIGHI, E. Z. Modificação da umidade relativa do ar pelo uso e manejo da estufa. Revista Brasileira de Agrometeorologia, v.7, n.2, 1999./No prelo/

BURIOL, G. A.; STTRECK, N. A.; PETRY, C.; SCHNEIDER, F. M. Transmissividade a radiação solar do polietileno de baixa densidade utilizado em estufa. Ciência Rural, Santa Maria, v.25, n.1, p.1-4, 1995.

CARON, B. O. Consumo d'água e coeficiente de cultura do meloeiro cultivado na primavera em estufa plástica. Santa Maria, 1999. Dissertação (M.S.) - Universidade Federal de Santa Maria.

CASSERES, E. Produción de Hortalizas. Instituto Interamericano de cooperacion para la Agricultura. San José, Costa Rica, 1984. 387p.

CERMEÑO, Z. S. Cultivo de Hortalizas en invernaderos. Barcelona, Editorial AEDOS, 1979, 360p.

CHAMARRO LAPUERTA, J. Anatomia y fisiologia de la planta. In: NUEZ, V. F. EI Cultivo del Tomate. Madrid: Mundi-Prensa, 1995. p.43-91.

COCKSHULL, K. E.; GRAVES, G. J.; CAVE, C. R. J. The influence of shading on yield of glasshouse tomatoes. J. Hortic. Sci., Oshford, v.67, n.67, p.11-24, 1992.

DALSASSO, L. C. Consumo de água e coeficiente de cultura do tomateiro (Lycopersicum esculentum, M.) e do pepino (Cucumis sativus, L.) cultivados em estufas plásticas. Santa Maria, 1997. 84p. Dissertação (M.S.) - Universidade Federal de Santa Maria. 
DE GRAAF, R.; VAN DEN ENDE, J. Transpiration and evapotranspiration of the glasshouse crops. Acta Horticulturae, v.119, 147-158, 1981.

DE VILLELE, O. Besoins en eau des cultures sous serre: essai de conduite des arrosagesen function de l'ensoleillement. Acta Horticulturae, v.35, p.123-129, 1972.

DOOREMBOS, J.; PRUITT, W. O. Guidelines for predicting crop water requeriments. FAO Irrigation and Drainage Paper 24, 2nd ed., Rome, 179p. 1977.

ESQUINAS-ALCAZAR, I; NUEZ, V F. Situacion taxonomica, domesticacion y difusion del tomate. In: NUEZ, V. F. El cultivo del tomate. Madrid: Mundi-Prensa, 1995. p.43-91.

ESTEFANEL, V.; MANFRON, P. A.; SACCOL, A. V.; et al. Análise das temperaturas do ar ocorridas em Santa Maria, RS. II - Probabilidade das datas de ocorrência das temperaturas mínimas do ar compreendidas no intervalo de -1 a $9^{\circ} \mathrm{C}$. Rev. do Centro de Ciências Rurais, Santa Maria, v.18, n.1, p.15-28, 1988.

ESTEFANEL, V.; SCHNEIDES, F. M.; BERLATTO, M. A.; BURIOL, G. A.;HELDWEIN, A. B. Insolação e radiação solar de Santa Maria, RS: I Estimativa da radiação solar global incidente a partir dos dados de insolação. Rev. Centro de Ciências Rurais, Santa Maria, v.20, n.3-4, p.303-218, 1990.

ESTEFANEL, V.; SCHNEIDER, F. M.; BURIOL, G. A. Probabilidade de ocorrência de temperaturas máximas do ar prejudiciais aos cultivos agrícolas em Santa Maria, RS. Revista Brasileira de Agrometeorologia, Santa Maria, v.2, p.57-63, 1994.

ESTEFANEL, V.; BURIOL, G. A.; ANDRIOLO, J. L.; LIMA, C. P.; LUZZI, N. Disponibilidade de radiação solar nos meses de inverno para o cultivo do tomateiro (Licopersicum esculentum Mill.) em ambiente protegido na Região de Santa Maria, RS. Ciência Rural, Santa Maria, v.28, n.4, p.553-559, 1998.

FAO. Protected cultivation in the mediterranean climate. Food and Agriculture Organization of the United Nations, Rome, FAO, 1990, 313p. ( FAO Plant Production and Protection Paper, n. 90). 
FARIAS, J. R. B. Resposta do Feijão-de-vagem à disponibilidade hídrica associada a alterações microbiológicas em estufas plásticas. Porto Alegre, 1991, 177p. Tese (Doutorado) - Universidade Federal do Rio Grande do Sul.

FARIAS, J. R. B.; BERGAMASCHI, H.; MARTINS, S. R.; BERLATO, M. A.; OLIVEIRA. A. C. B. Efeito da cobertura plástica da estufa sobre a radiação solar. Revista Brasileira de Agrometeorologia, Santa Maria, v.1, n.1, p.31-36, 1993a.

FARIAS, J. R. B.; BERGAMASCHI, H.; MARTINS, S. R.; BERLATO, M. A.; OLIVEIRA, A. C. B. Alterações na temperatura e umidade relativa do ar provocadas pelo uso de estufas plásticas. Revista Brasileira de Agrometeorologia, Santa Maria, v.1, n.1, p.31-36, 1993b

FILGUEIRA, F. A. R. Manual de Olericultura. Cultura e Comercialização de Hortaliças. $2^{a}$ ed. São Paulo: Agronômica Ceres, 1982. v. 2, 357p.

GARY, C.; BAILLE, A.; NAUARRETE, M.; ESPANET, R. TOMPOUSE, Un modéle de previsión du rendiment et du calibre de la tomate. In: Séminaire de LÁIP "serres", Alenya, 1996. 10p.

HELDWEIN, A. B.; STRECK, N. A.; SCHINEIDER, F. M.; et al. Efeito da cobertura plástica sobre a temperatura mínima do ar. In: IX CONGRESSO BRASILEIRO DE AGROMETEOROLOGIA, Campina Grande, 1995. Anais. Campina Grande, 1995. p.304-306.

JOLLIET, O.; BAILEY, B. J. The effect of climate on tomato transpiration in greenhouses: measurements and models comparison. Agricultural and Forest Meteorology, v.58, p.43-62, 1992.

JOLLIET, O.; BAILEY, B. J.; HAND, D. J.; COCKSHULL, K. Tomato yeld in greenhouses related to humidity and transpiration. Acta Horticulturae, v.328, p.115-124, 1993.

KINET, J. M. Effect of light conditions in the development of the inflorescence in tomato. Scientia Horticulturae, Amsterdam, v.6, p.15-26, 1977.

KRAMER, P. J.; BOYER, J.S. Water relations of plants and soils. Academic Press limited, Lodon, 1995. 493P. Il. 
MAKISHIMA, N. A situação da Pesquisa do Tomateiro no Brasil. In: I ENCONTRO NACIONAL DE PRODUÇÃO E ABASTECIMENTO DE TOMATE, 1989, Minas Gerais. Anais..., Minas Gerais, 1989; p.108-116.

MARTIN, E. C.; NOVOA, A. C.; GOMES, S. J. Estudio comparativo de las propriedades de diversos materiales utilizados como cubierta en cultivos protegidos. Revista de Plásticos Modernos, v.308, p. 185-189, 1982.

MARTINEZ GARCIA, P. F. Caracteristicas climáticas de los invernadores de plástico. Madrid: Instituto Nacional de investigaciones Agrárias - INIA, 1978. 48p. (Hojas Tecnicas, 19)

MILLIS, P. J. W.; SMITH, I. E; MORIS, G. A greenhouse design for a cool subtropical climate with mild winters based in microclimatic mesuraments of protected environments. Acta Horticulturae, Wageningen, v.281, p.83-93, 1990.

MONTERO, J. I.; CASTILLA, N.; GUTIERREZ DE RAUÉ, E., et al., Climate under plastic in the Almeria area. Acta Horticulturae, Wageningen, v.17, p.227-234, 1985.

MURAYAMA, S. Horticultura. Instituto Campineiro de Ensino Agrícola, Campinas, 1972.675p.

OKUYA, A.; OKUYA, T. The transpiration of greenhouse tomato plants in rockwool culture and its relationship to climatic fators. Acta Horticulturae, v.230, p.307$311,1988$.

PEREIRA, A. R.; VILLA NOVA, N. A.; SEDYIAMA, G. C. Evapo(transpi)ração. Piracicaba: FEALQ, 1997. 183p.: il.

PICKEN, A. J. F.; STEWART, K.; KLAPWIJK. D. Germination and vegetative development. In: ATHERTON, J.G; RUDICH, J. (Eds). The tomato Crop. New York: Chapman na Hall Ltd., 1986. p.111-165: Germination and vegetative development.

PRADOS, N. C. Contribución al estudio de los cultivos enarenados en Almeria: necessidades hídricas y extración del nutrientes del cultivo de tomate de crescimneto indeterminado en abrigo de polietileno. Almeria, Espana, 1986. 1950p. Tesis (Doutorado) - Caja Rural Principal. 
RAVESTJIN, W. Seting of fruit in tomatoes, pappers and strawberries. Ann. Rep. Glasshouse Crops Res. Exp. Stat. Naaldwijk, p.57-62, 1970.

RICK, C. M. The tomato. Scientific American, New York, v.239, p.67-76, 1978.

ROBLEDO DE PEDRO, F. Laminas de polietileno y copolimero EVA para usos en agricultura. Hojas Divulgadoras. v. 2, p.1-20, 1987.

ROBLEDO DE PEDRO, F.; MARTIN, L. V. Aplicación de los plasticos en la agricultura. Madrid: Mundi-Prensa. 1981. 552p.

ROBLEDO DE PEDRO, F; MARTIN, L. V. Aplicacion de los plasticos en la . agricultura. 2: ed. Madrid: Mundi-Prensa, 1988. 573 p.

ROSEMBERG, N.J. Microclimate: the biological environment. New York: John Willey, 1974. 315p.

RUTTER, A. J. The hydrological cycle in vegetation. In: MONTEITH, J. L. Vegetation and the Atmosphere. London: Academic Press Inc. LTD, 1975. Capítulo 4, p.112154.

SCATOLINI, M. E. Estimativa da evapotranspiração da cultura do crisântemo em estufa a partir de elementos meteorológicos. Piracicaba, 1996. 65p. (Dissertação (M.S.) - Escola Superior de Agricultura "Luiz de Queiroz", Universidade de São Paulo.

SEEMANN, J. Greenhouse climate. In: SEEMAN, J. et al., Agrometeorology. Berlin Heidlberg: Springer-Verlag, 1979. p.165-178: Greenhouse climate.

SPOHR, R. B.; STRECK, N. A.; SANDRI M. A. Estimativa da área foliar do tomateiro (Lycopersicom esculentum) híbrido Monte Carlo a partir do comprimento e largura da folha. In.: Jornada integrada pesquisa, extensão e ensino. Anais. (Ciências rurais): 1997, p.839, $877 \mathrm{p} . /$ Resumo/

STANGHELLINI, C. Transpiration of greenhouse crops, na aid to climate management. Wageningen, 1987. 150p. Dissertação (Ph.D.) - Agricultural University.

STANGHELLINI, C.; VAN MEURS, W. TH.M. Environmental control of greenhouse crop transpiration. J. Agric. Eng. Res., v.51, p.297-311, 1992. 
STANGHELLINI, C. Environmental effect on growth and its implications for climate management in "Mediterranean" greenhouses. Acta Horticulturae, v.361, p.57-66, 1994.

STANHILL, G. : SCHOLTE ALBERS, J. Solar radiation and water loss from glasshouse roses. J. Amer. Soc. Hort. Sci, v.99, n.2, p.107-110, 1974.

TANAKA, M. \& GENTA, H. Comparación de la temperatura en diferentes sistemas protegidos de primor. Salto, Centro de investigaciones Agricolas "Alberto Boerges"/Estación Experimental de Citricultura, 1983. 24p.

TAVARES de MELO, P.C. Tendências do melhoramento do tomateiro visando mesa e indústria no Brasil. II Encontro Nacional de Produção e Abastecimento de tomate. Jaboticabal, FCAV. UNESP, SP, 1991.

TETENS, O. Uber einige meteorologische Begriffe. Z. Geophys, v.6, p.297-309, 1930.

TUBELIS, A.; NASCIMENTO, F. J. L. Meteorologia Descritiva. Fundamentos e Aplicações Brasileiras, $1^{\mathrm{a}}$ ed., $4^{\mathrm{a}}$ reimpressão, São Paulo, 1986. 374p.

VALANDRO, J. Transpiração do tomateiro cultivado fora do solo em estufa plástica e sua relação com os elementos meteorológicos e parâmetros de crescimento. Santa Maria, 1999.67p. Dissertação (M.S.). Universidade Federal de Santa Maria.

YANG, X.; SHORT, T. H., FOX, R. D.; BAUERLE, W. Transpiration, leaf temperature and stomatal resistance of a greenhouse cucumber crop. Agricultural and Forest Meteorology, v.51, p.197-209, 1990. 